\title{
Scope and limitations of the solution and solid phase synthesis of homoallylic amines via $N$-acyliminium ion reactions
}

\author{
Wim J. N. Meester, ${ }^{a}$ Jan H. van Maarseveen, ${ }^{a}$ K. Kirchsteiger, ${ }^{a}$ Pedro H. H. Hermkens, ${ }^{b}$ \\ Hans E. Schoemaker, ${ }^{c}$ Henk Hiemstra, ${ }^{a}$ and Floris P. J. T. Rutjes ${ }^{a, d}$ \\ ${ }^{a}$ IMC, University of Amsterdam, Nieuwe Achtergracht 129, 1018 WS Amsterdam, \\ The Netherlands \\ ${ }^{b}$ NV Organon, Lead Discovery Unit, PO Box 20, 5340 BH Oss, The Netherlands \\ ${ }^{c}$ DSM Life Science Products, PO Box 18, 6160 MD Geleen, The Netherlands \\ ${ }^{d}$ Department of Organic Chemistry, NSRIM, University of Nijmegen, \\ Toernooiveld 1, 6525 ED Nijmegen, The Netherlands \\ E-mail:rutjes@sci.kun.nl
}

This paper is dedicated to Prof. Binne Zwanenburg on the occasion of his $\mathbf{7 0}^{\text {th }}$ birthday

(received 31 Oct 03; accepted 17 Dec 03; published on the web 29 Dec 03)

\begin{abstract}
The full scope and limitations of solution and solid phase one-pot three component $N$ acyliminium ion reactions are detailed. After studying the scope in solution with respect to the carbamate, nucleophile and aldehyde component, a 'translation' was made to the solid phase. The solid phase reactions were eventually carried out using the so-called SEC linker system, which was previously developed in our group. In order to maximize the scope of the nucleophile component, additional studies were successfully conducted using two-step processes involving stable $N$-acyliminium ion precursors.
\end{abstract}

Keywords: $N$-Acyliminium ion, multicomponent reaction, solid phase chemistry, homoallylic amines, combinatorial chemistry

\section{Introduction}

In the past decade, numerous types of reactions have been 'translated' from the solution to the solid phase, so that solid phase combinatorial chemistry may currently enable the synthesis of various compound libraries of any size. ${ }^{1}$ However, solid phase reactions should not simply deliver as many compounds as possible, but rather as 'diverse' compounds as possible. Therefore, in the process of 'translating' solution phase reactions to the solid phase, one should 
consider that establishing the scope and limitations on the solid phase in terms of variety in functionality, steric and electronic properties must be an integral aspect of this process.

In a series of publications, it was shown by our group ${ }^{2,3,4,5}$ and by others ${ }^{6}$ that $N$-acyliminium ion chemistry can be efficiently carried out on a solid phase, provided that an appropriate linker system is used. With the development of the novel polystyrene-based SEC and TEC linker systems, ${ }^{3-5}$ an adequate immobilization approach was found in our group. By using these linkers, extensive and more systematic investigations in the scope and limitations of solid phase $N$ acyliminium ion chemistry can be performed. In conjunction with a preliminary publication on one-pot three component $N$-acyliminium ion reaction for the synthesis of homoallylic amines, ${ }^{2}$ this paper will detail a full account of the scope and limitations of this reaction.

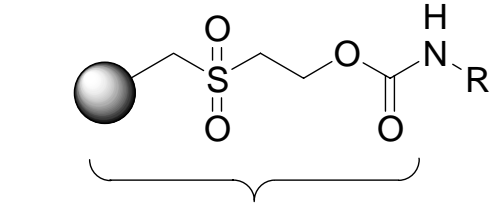

sulfonylethoxycarbonyl (SEC) linker

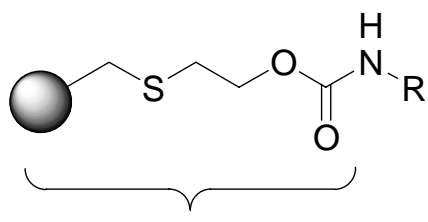

thioethoxycarbonyl (TEC) linker

In the solution phase one-pot three component synthesis of protected homoallylic amines introduced by Panek ${ }^{7}$ and Veenstra, ${ }^{8}$ studies on the scope of this $N$-acyliminium ion reaction with respect to the amide and aldehyde components were reported (Scheme 1). These studies showed that a wide variety of aromatic and aliphatic aldehydes could be used in combination with some carbamates and sulfonamides. Electron rich and poor aromatic aldehydes reacted equally well and steric bulk in the aldehyde component did not seem to play a significant role.

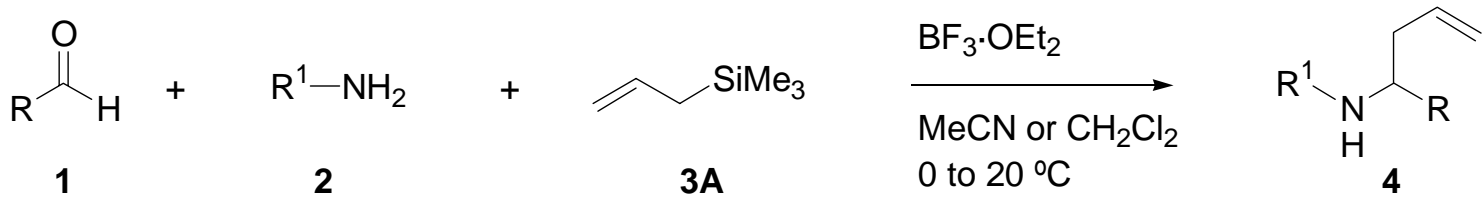

\section{Scheme 1}

In this contribution, studies to reach a broader scope of the corresponding solid phase three component $\mathrm{N}$-acyliminium ion reaction will be presented to give the corresponding homoallylic amines. ${ }^{9}$, For a better understanding of the solid phase reaction, these investigations started with a more detailed scope determination using solution phase model systems. A significant part of the research focused on the use of reactive species (generated in situ or isolated) that subsequently could be used as $\mathrm{N}$-acyliminium ion precursors. During the course of our work, the group of Mioskowski reported a similar type of approach, ${ }^{10}$ in which via a three-component reaction from amides, aldehydes and trimethyl orthoformate a stable $\mathrm{N}, \mathrm{O}$-acetal was isolated and used as an $\mathrm{N}$-acyliminium ion precursor in a subsequent step. This concept may lead to a 'two- 
step' rather than a one-pot process, but which eventually might improve the diversity of the resulting products of the $N$-acyliminium ion reaction.

\section{Results and Discussion}

In order to synthesize the solution phase model systems, 2-(benzylsulfonyl)ethyl carbamate 8 and the corresponding 2-(benzylthio)ethyl carbamate 9 were obtained using the technology described for the synthesis of the SEC and TEC linker systems. ${ }^{3,4}$ To facilitate the purification of the products, the reagents were used in slight excess or in equimolar amounts to provide both carbamates 8 and 9 in good overall yields (78\% and 76\% over three and two steps, respectively).

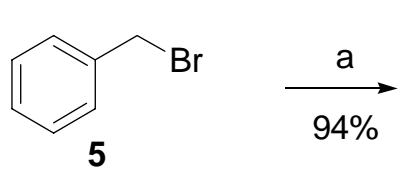

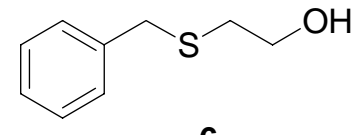

6
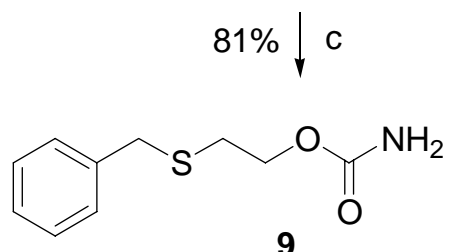

9
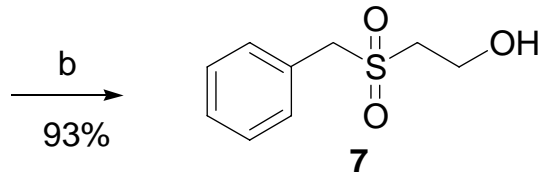

$89 \% \downarrow$

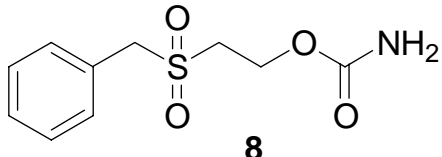

Scheme 2. Reagents and conditions: (a) $\mathrm{Cs}_{2} \mathrm{CO}_{3}$ (1.05 equiv), mercaptoethanol (1.05 equiv), $\mathrm{DMF}, 60^{\circ} \mathrm{C}, 4 \mathrm{~h}, \mathrm{rt}, 18 \mathrm{~h}$; (b) $m \mathrm{CPBA}$ (2.3 equiv), $\mathrm{CH}_{2} \mathrm{Cl}_{2}, 0^{\circ} \mathrm{C} \rightarrow \mathrm{rt}, 18 \mathrm{~h}$; (c) (1) p-nitrophenyl chloroformate (1.0 equiv), $\mathrm{N}$-methylmorpholine (1.0 equiv), $\mathrm{CH}_{2} \mathrm{Cl}_{2}, 0{ }^{\circ} \mathrm{C} \rightarrow \mathrm{rt}, 18 \mathrm{~h}$; (2) $\mathrm{NH}_{3}$, $\mathrm{MeOH} / \mathrm{DMF}, \mathrm{rt}, 18 \mathrm{~h}$.

Allyl carbamate 10 and benzotriazole $(\mathrm{Bt})$ derivative $\mathbf{1 1}$ were also prepared as model systems for solution phase $\mathrm{N}$-acyliminium ion reactions. The two compounds were prepared according to known literature procedures. Allyl carbamate $\mathbf{1 0}$ was obtained in one step from allyl chloroformate using the procedure of Roos et al., ${ }^{11}$ while Bt-derivative $\mathbf{1 1}$ was obtained in one step from benzyl carbamate using Katritzky technology. ${ }^{12}$ Bt-compounds usually exist as a mixture of 1-yl and 2-yl isomers (viz. structures 1-yl-11 and 2-yl-11), both of which display a comparable leaving group ability. ${ }^{13}$ However, Bt-derivative 11 was mainly isolated as the pure 1yl-11 isomer. ${ }^{12}$<smiles>C=CCOC(N)=O</smiles>

10

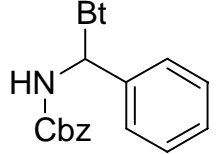

11

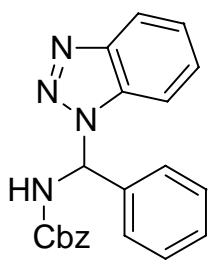

$1-\mathrm{yl}-11$

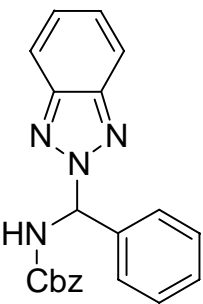

2-yl-11 
Evidently, allyl carbamate $\mathbf{1 0}$ was used as a model system for the allyl carbamate linker, while carbamates 8 and $\mathbf{9}$ were used as models for the corresponding SEC and TEC linker systems. Benzyl carbamate was used as a simple and readily available model system for a generally immobilized carbamate. To explore the two-step variant of the three component $\mathrm{N}$ acyliminium ion reaction, Bt-derivative $\mathbf{1 1}$ was used.

First, the scope of the three component $N$-acyliminium ion reaction with allyl carbamate $\mathbf{1 1}$ was investigated. This carbamate was reacted with 1 equiv of aldehydes 12a-f, nucleophile 3A-F and $\mathrm{BF}_{3} \cdot \mathrm{OEt}_{2}$ in $\mathrm{CH}_{2} \mathrm{Cl}_{2}$ at $\mathrm{rt}$. The reactions were quenched upon disappearance of the starting material or after a maximum reaction time of $20 \mathrm{~h}$. Several aromatic and aliphatic aldehydes were used in combination with allyltrimethylsilane (3A). Furthermore, benzaldehyde (12a) was used in combination with several nucleophiles (Table 1).

Table 1

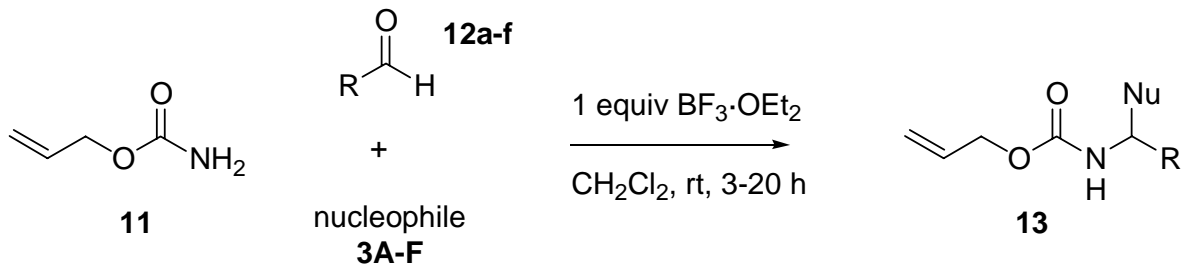

\begin{tabular}{|c|c|c|c|c|c|c|}
\hline Entry & $\mathrm{R}$ & Nucleophile & & $\begin{array}{l}\text { Time } \\
\text { (h) }\end{array}$ & $\mathrm{Nu}$ & Product (yield) \\
\hline 1 & $\mathrm{Ph}(\mathbf{1 2 a})$ & & (3A) & 3 & & 13aA (82\%) \\
\hline 2 & $p-\mathrm{MeOC}_{6} \mathrm{H}_{4}(\mathbf{1 2 b})$ & 3A & & 3 & & 13bA (80\%) \\
\hline 3 & $p-\mathrm{NCC}_{6} \mathrm{H}_{4}(\mathbf{1 2 c})$ & $3 \mathbf{A}$ & & 20 & & 13cA $(45 \%)$ \\
\hline 4 & $p-\mathrm{O}_{2} \mathrm{NC}_{6} \mathrm{H}_{4}(\mathbf{1 2 d})$ & 3A & & 20 & & 13dA $(40 \%)$ \\
\hline 5 & $i-\operatorname{Pr}(\mathbf{1 2 e})$ & 3A & & 20 & & 13eA $(44 \%)$ \\
\hline 6 & $\operatorname{Bn}(\mathbf{1 2 f})^{a}$ & 3A & & 20 & & 13fA $(75 \%)$ \\
\hline 7 & $\mathrm{Ph}(\mathbf{1 2 a})$ & & (3B) & 20 & & 13aB $(80 \%)$ \\
\hline 8 & $\mathrm{Ph}(\mathbf{1 2 a})$ & & (3C) & 20 & & 13aC $(10 \%)$ \\
\hline 9 & $\operatorname{Ph}(\mathbf{1 2 a})$ & $\mathrm{Me}_{3} \mathrm{~s}$ & (3D) & 20 & & 13aD (5\%) \\
\hline 10 & $\mathrm{Ph}(\mathbf{1 2 a})$ & & (3E) & 20 & & 13aE (10\%) \\
\hline 11 & $\mathrm{Ph}(\mathbf{1 2 a})$ & & (3F) & 20 & & 13aF (6\%) \\
\hline
\end{tabular}

${ }^{a}$ The corresponding diethyl acetal was used. 
As shown in the Table, electron rich aromatic aldehydes (entries 1-2) gave the best results, while the electron poor aromatic aldehydes (entries 3-4) resulted in the formation of the desired homoallylic carbamate in moderate yields and longer reaction times. The same was true for the aliphatic substituents (entries 5-6). With respect to the nucleophile, the scope proved to be significantly narrower. Although the use of the substituted allylsilane 3B (entry 7) resulted in a high yield of the desired product $(80 \%)$, the reaction was much slower than with allyltrimethylsilane (3A, entry 1). 1,2-Propadienyltributylstannane (3C) has been successfully used previously as a nucleophile in $N$-acyliminium ion chemistry. ${ }^{14}$ However, in this case, the use of the stannane (entry 8) only resulted in the formation of the desired homopropargylic carbamate $13 \mathrm{aC}$ in a yield of $10 \%$. The use of $\mathrm{Me}_{3} \mathrm{SiCN}$ (entry 9) and silyl enol ethers (entries 10-11) gave traces of the desired products, although these nucleophiles have previously shown their viability in $\mathrm{N}$-acyliminium ion chemistry. ${ }^{15,16}$ The low yields achieved with the nucleophiles 3C-F might be explained by the rather low stability of these compounds under the conditions needed for the formation of the $N$-acyliminium ion $\left(\mathrm{BF}_{3} \cdot \mathrm{OEt}_{2}, \mathrm{rt}\right)$.

Table 2

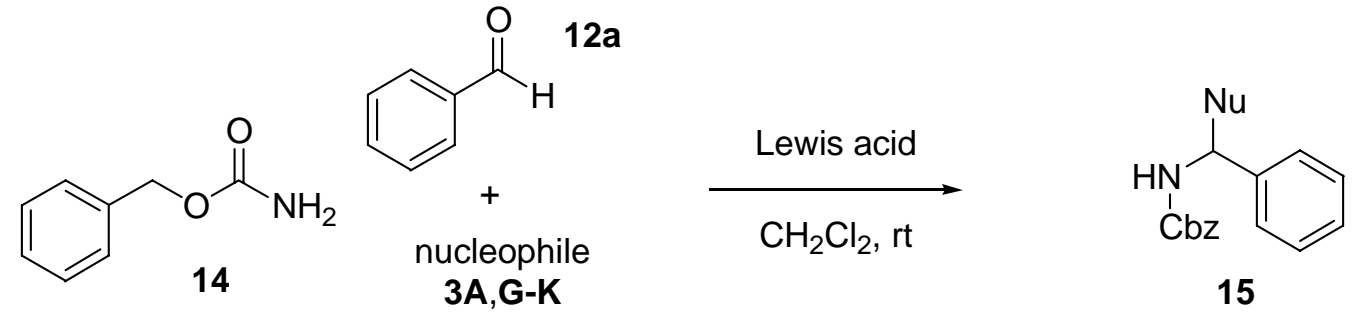

\begin{tabular}{|c|c|c|c|c|c|c|}
\hline Entry & Nucleophile & & $\begin{array}{c}\text { Lewis } \\
\text { Acid }\end{array}$ & $\begin{array}{c}\text { Time } \\
\text { (h) }\end{array}$ & $\mathrm{Nu}$ & Product (yield) \\
\hline 1 & 3A & & $\mathrm{BF}_{3} \cdot \mathrm{OEt}_{2}$ & 3 & & 15aA $(92 \%)$ \\
\hline 2 & & (3G) & $\mathrm{BF}_{3} \cdot \mathrm{OEt}_{2}$ & 4 & & 15aG (71\%) \\
\hline 3 & & (3H) & $\mathrm{BF}_{3} \cdot \mathrm{OEt}_{2}$ & 20 & C & - \\
\hline 4 & $e_{3}$ & (3I) & $\mathrm{BF}_{3} \cdot \mathrm{OEt}_{2}$ & 20 & & - \\
\hline 5 & & $(3 \mathbf{J})$ & $\mathrm{BF}_{3} \cdot \mathrm{OEt}_{2}$ & 4 & & 15aJ $(62 \%)$ \\
\hline 6 & & $(3 \mathbf{K})$ & $\mathrm{BF}_{3} \cdot \mathrm{OEt}_{2}$ & 20 & & - \\
\hline 7 & $(3 \mathbf{K})$ & & $\mathrm{Sc}(\mathrm{OTf})_{3}{ }^{a}$ & 18 & & 15aK $(28 \%)$ \\
\hline
\end{tabular}

${ }^{a}$ A catalytic amount of the Lewis acid ( 0.1 equiv) was used. 
The scope of the solution phase one-pot three component $\mathrm{N}$-acyliminium ion reaction with respect to the nucleophile was further investigated using benzyl carbamate (14) as a model system (Table 2). The 1-substituted allylsilane 3G (entry 2) reacted smoothly and resulted in a $71 \%$ yield of homoallylic carbamate 15aG. The geometry of the newly formed double bond was assigned by ${ }^{1} \mathrm{H}$ NMR experiments and proved to be exclusively (E). Suprisingly, 2- and 3substituted allylsilanes $\mathbf{3 H}$ and $\mathbf{3 I}$ (entries 3-4) did not lead to any product formation at all. The steric hindrance of the chloride and methyl substituent on the reactive double bond of the allylsilane might explain the poor reactivity of these nucleophiles in this specific $\mathrm{N}$-acyliminium ion reaction. Although the use of 2,3-butadienylsilane 3J in Sakurai-type additions to aldehydes and acetals has been reported by the groups of Hatakeyama and Takano, ${ }^{17}$ the use of this nucleophile in $\mathrm{N}$-acyliminium ion reactions has received only recent attention. ${ }^{18}$ The application of allenylsilane $\mathbf{3} \mathbf{J}$ in the one-pot three component $N$-acyliminium reaction with benzyl carbamate (14) and benzaldehyde (12a) resulted in the formation of diene 15aJ in a yield of $62 \%$. Analogous to the unsuccessful use of silyl enol ethers (Table 1), at this point the more stable vinyl acetate 3K was used as a nucleophile (entries 6-7). However, under the conditions that were previously used for the formation of the transient cation ( 1 equiv $\mathrm{BF}_{3} \cdot \mathrm{OEt}_{2}$, entry 6 ), no product was formed either. Recently, new developments to generate iminium and $N$-acyliminium ion intermediates by using catalytic amounts of metal triflates $\left(\mathrm{Sc}(\mathrm{OTf})_{3}, \mathrm{Yb}(\mathrm{OTf})_{3}, \mathrm{Sn}(\mathrm{OTf})_{2}\right.$, $\mathrm{Hf}(\mathrm{OTf})_{4}$, etc.) have been reported by Kobayashi et al. ${ }^{19}$ When the Lewis acid was changed to catalytic $\mathrm{Sc}(\mathrm{OTf})_{3}$ (entry 7), the desired ketone $\mathbf{1 5 a K}$ was obtained, albeit in a low yield of $28 \%$. To gain a better understanding of the 'translation' of the $N$-acyliminium ion reaction to the SEC and TEC linkers that we eventually would like to apply, the model reactions were extended to carbamates having the sulfonylethyl and thioethyl functionalities already present in the molecule. Thus, carbamates 8 and $\mathbf{9}$ were used for the one-pot three component reactions (Table 3).

\section{Table 3}

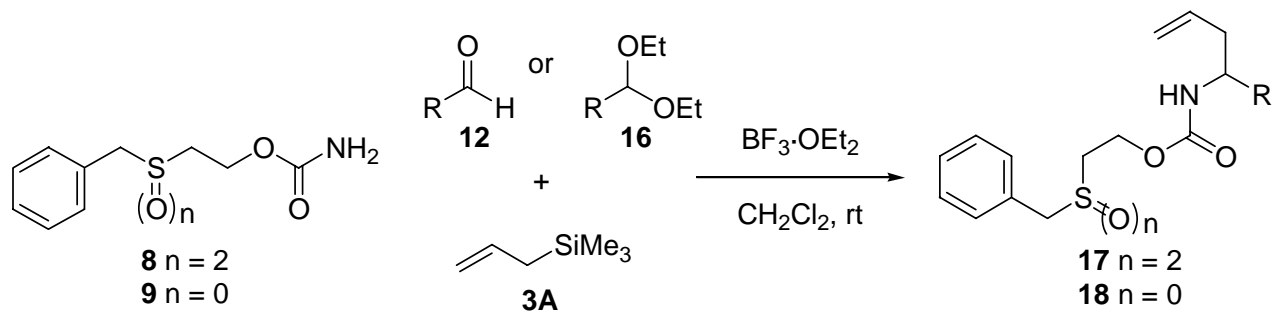

\begin{tabular}{ccccc}
\hline Entry & Carbamate & R (Aldehyde/Acetal) & Time $(\mathrm{h})$ & Product (yield) \\
\hline 1 & $\mathbf{8}$ & Ph (12a) & 4 & $\mathbf{1 7 a A}(89 \%)$ \\
2 & $\mathbf{8}$ & Bn $(\mathbf{1 6 f})$ & $6^{a}$ & $\mathbf{1 7 f A}(82 \%)$ \\
3 & $\mathbf{9}$ & Ph $(\mathbf{1 2 a})$ & 5 & $\mathbf{1 8 a A}(65 \%)$ \\
4 & $\mathbf{9}$ & $n$-hexyl $(\mathbf{1 2 g})$ & 18 & $\mathbf{1 8 g A}(45 \%)$ \\
5 & $\mathbf{9}$ & $n$-hexyl $(\mathbf{1 6 g})$ & 18 & $\mathbf{1 8 g A}(66 \%)$ \\
\hline
\end{tabular}

${ }^{a}$ Reaction at $50{ }^{\circ} \mathrm{C}$. 
The yield of sulfonylethyl carbamate 17aA (89\%, entry 1) was comparable with the yield earlier obtained in combination with allyl carbamate 11 (82\%, Table 1, entry 1$)$. However, the same components in combination with thioethyl carbamate $\mathbf{9}$ afforded product $\mathbf{1 8 a A}$ in a somewhat lower yield (65\%, entry 3). This finding was comparable to solid phase results obtained with other $\mathrm{N}$-acyliminium ion reactions on the SEC and TEC linker systems. ${ }^{4}$ The lower yields with thioethyl carbamate 9 and the corresponding TEC resin might be explained by the presence of the nucleophilic sulfur functionality, which could interfere with the reaction conditions that are required for the $N$-acyliminium ion reaction. A benzylic substituent was introduced using the diethyl acetal $\mathbf{1 6 f}$ (entry 2), which was used because of the poor stability of the corresponding aldehyde. Logically, this diethyl acetal functionality also generated a more reactive precursor for the $\mathrm{N}$-acyliminium ion formation (an $\mathrm{N}, \mathrm{O}$-acetal rather than an $\mathrm{N}, \mathrm{O}$ hemiacetal) and thus resulted in the smooth formation of product 17fA in a yield of $82 \%$. The same positive effect of the diethyl acetal functionality was found with the introduction of an $n$ hexyl substituent (entries 4-5). While $n$-heptanal (12g) produced the product 18gA in a yield of only $45 \%$, the use of the corresponding diethyl acetal $16 \mathrm{~g}$ improved the yield of $18 \mathrm{gA}$ to $66 \%$.

To further investigate the scope with respect to the aliphatic diethyl acetal component, benzyl carbamate (14) and allyltrimethylsilane (3A) were used in combination with the functionalized aliphatic diethyl acetal $\mathbf{1 6 h}$ (Scheme 3). After a reaction time of $18 \mathrm{~h}$, a $75 \%$ conversion of benzyl carbamate (14) was observed and during the reaction a white precipitate was formed, which after isolation was identified as bis-carbamate 21. The formation of similar bis-carbamates in this type of reaction was also reported by Veenstra. ${ }^{8}$ However, the bis-carbamate precipitate was by them observed at the beginning of the reaction and was thereafter completely transformed into the desired product. In our hands, the bis-carbamate $\mathbf{2 1}$ and the desired protected diamine 15hA were obtained as a 1:1 mixture, which could be easily separated using column chromatography. Subsequently, bis-carbamate 21 itself was used as an $N$-acyliminium ion precursor, which after a reaction of $18 \mathrm{~h}$ resulted in a 6:4 mixture of compounds $\mathbf{2 1}$ and $\mathbf{1 5 h \mathbf { h }}$.

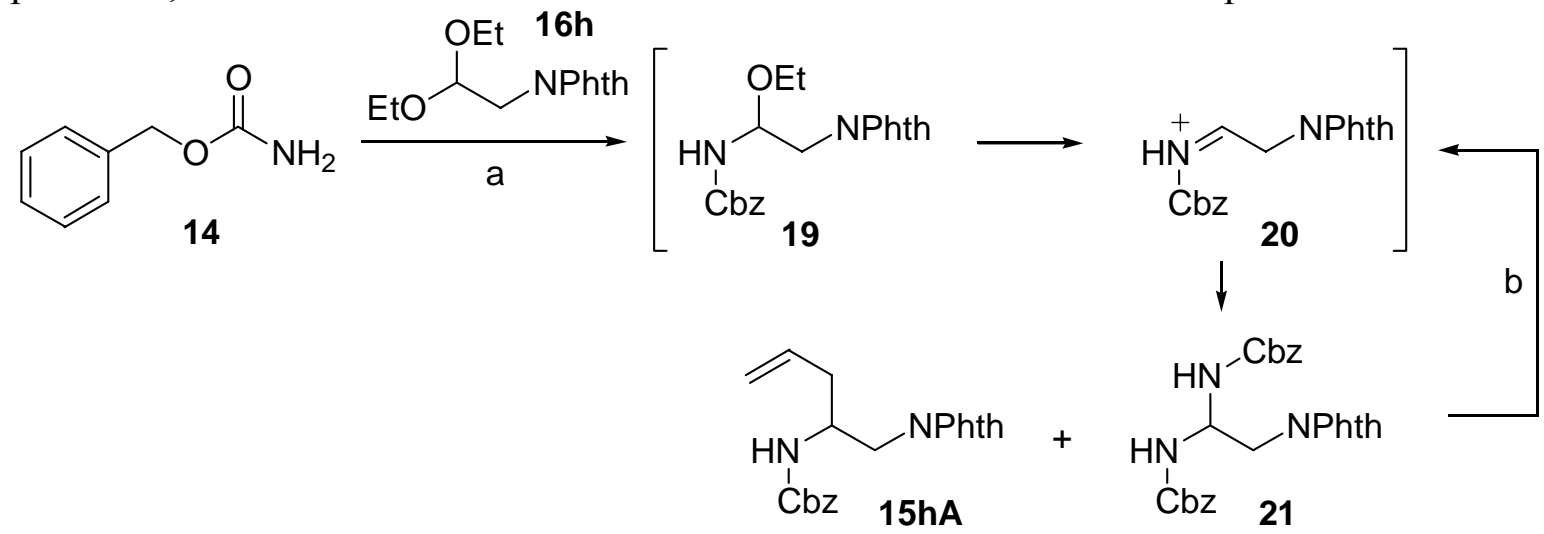

Scheme 3. Reagents and conditions: (a) $3 \mathrm{~A}$ (1 equiv), $\mathrm{BF}_{3} \cdot \mathrm{OEt}_{2}$ (1 equiv), $\mathrm{CH}_{2} \mathrm{Cl}_{2}, \mathrm{rt}, 18 \mathrm{~h}(75 \%$ conversion, 1:1 mixture of 21 and 15hA); (b) 3A (1 equiv), $\mathrm{BF}_{3} \cdot \mathrm{OEt}_{2}$ (1 equiv), $\mathrm{MeCN}, \mathrm{rt}, 18 \mathrm{~h}$ (6:4 mixture of $\mathbf{2 1}$ and $\mathbf{1 5 h} \mathbf{A})$. 
Clearly, the scope of the three component $N$-acyliminium ion reaction in particular with respect to the nucleophile is still rather limited. Encouraged by the results of using more activated intermediates for the $\mathrm{N}$-acyliminium ion formation, it was decided to further investigate the 'two-step' approach. In contrast to Mioskowski's results with aromatic amides, ${ }^{10}$ in our hands the addition of aldehydes to benzyl carbamate in the presence of TFA and $\mathrm{HC}(\mathrm{OMe})_{3}$ did not lead to the desired $\mathrm{N}, \mathrm{O}$-acetal, but resulted in the exclusive formation of the corresponding bis-carbamates. ${ }^{20}$ Therefore, in addition to $\mathrm{N}, \mathrm{O}$-acetals, the Bt-derivative $\mathbf{1 1}$ was used as a readily available and versatile $N$-acyliminium ion precursor (Table 5).

\section{Table 5}

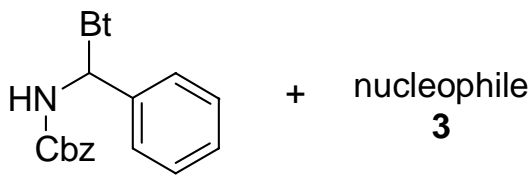

11

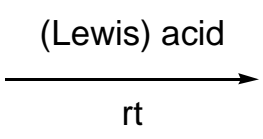

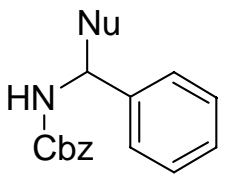

15

\begin{tabular}{ccccccc}
\hline Entry & Nucleophile 3 & $\begin{array}{c}\text { Lewis } \\
\text { Acid }\end{array}$ & Solvent & $\mathrm{Nu}$ & Product (yield) \\
\hline 1 & $\mathrm{BF}_{3} \cdot \mathrm{OEt}_{2}$ & $\mathrm{CH}_{2} \mathrm{Cl}_{2}$ & \\
\hline
\end{tabular}

By using allyltrimethylsilane (3A) as the nucleophile, homoallylic carbamate 15aA was obtained in a good yield ( $80 \%$, entry 1$)$, thus proving the viability and efficiency of this Btderivative in $\mathrm{N}$-acyliminium ion chemistry. 2,3-Butadienylsilane $\mathbf{3} \mathbf{J}$ (entry 2) was reacted with Bt-derivative 11 to provide diene 15aJ, the preparation of which was described earlier in Table 2 (entry 5). In the current case, diene 15aJ was obtained in a slightly lower yield than in the previous example (53\% and $62 \%$, respectively). The application of a vinylogous silyl enol ether as a nucleophile was demonstrated by the use of furan $\mathbf{3 L}$ (entries 3-4). ${ }^{21,22} \mathrm{Sc}(\mathrm{OTf})_{3}$ proved to be unsuitable for $\mathrm{N}$-acyliminium ion formation with Bt-derivative 11, since it led to no product formation at all. However, with the use of $\mathrm{BF}_{3} \cdot \mathrm{OEt}_{2}$, the desired $\alpha, \beta$-unsaturated lactone 15aL was obtained in a moderate yield of $51 \%$. The use of furan as an aromatic nucleophile in $N$ acyliminium ion chemistry has been shown before, ${ }^{23}$ in which the best results were obtained using moderately strong protic acids in combination with furan as the solvent. Thus, Btderivative 11 was reacted with CSA in furan (16 M) to afford compound 15aM in a yield of 55\% 
(entry 5). The introduction of the furan functionality may allow further functionalization by oxidation to the corresponding carboxylic acid functionality. Although a heterogeneous $\mathrm{RuO}_{2} / \mathrm{NaIO}_{4}$ system is usually used for the oxidation of $\alpha$-furyl carbamates, ${ }^{24}$ some examples of homogeneous oxidations with ozone are also known. ${ }^{25}$ Hence, furan 15aM was ozonolyzed to afford the $N$-protected phenylglycine derivative 26 in a yield of 79\% (Scheme 4). Consequently, with this reaction sequence,the scope of products was extended to Cbz-protected $\alpha$-amino acids.<smiles>O=C(NC(c1ccccc1)c1ccco1)c1ccccc1</smiles>

$15 \mathrm{aM}$

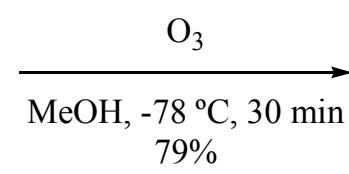

$$
79 \%
$$<smiles>O=C(NC(C(=O)O)c1ccccc1)OCc1ccccc1</smiles>

22

\section{Scheme 4}

Next, with the results of the solution phase $N$-acyliminium ion reactions in mind, the scope and limitations of the same reactions on a solid phase were determined. For this purpose, the earlier developed SEC linker system 23 was used. The introduction of aromatic side chains is presented in Table 6.

\section{Table 6}

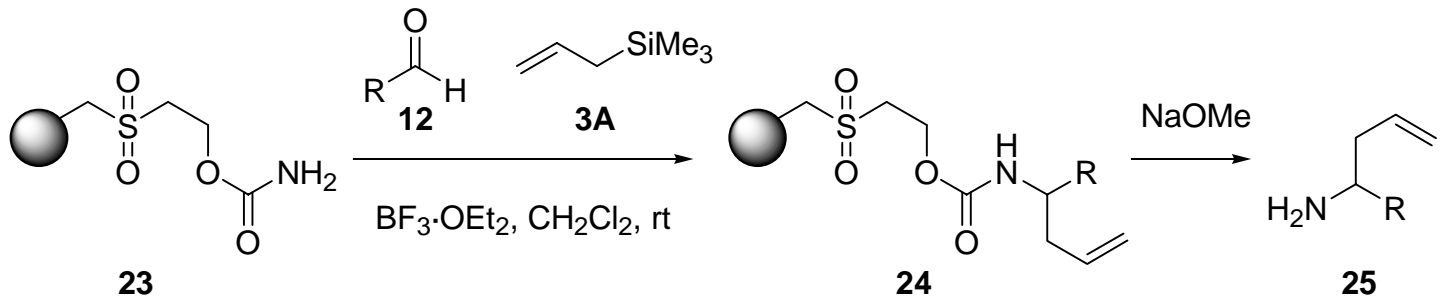

\begin{tabular}{ccc}
\hline Entry & $\mathrm{R}$ & ${\text { Product }(\mathrm{yield})^{a}}^{a}$ \\
\hline 1 & $\mathrm{Ph}(\mathbf{1 2 a})$ & 25aA $(80 \%)$ \\
2 & $p-\mathrm{MeOC}_{6} \mathrm{H}_{4}(\mathbf{1 2 b})$ & 25bA $(79 \%)$ \\
3 & $p-\mathrm{NCC}_{6} \mathrm{H}_{4}(\mathbf{1 2 c})$ & $25 \mathbf{c A}(39 \%)$ \\
4 & $p-\mathrm{O}_{2} \mathrm{NC}_{6} \mathrm{H}_{4}(\mathbf{1 2 d})$ & $\mathbf{2 5 d A}(<3 \%)$ \\
5 & $3-\mathrm{Thienyl}^{(\mathbf{1 2 i})}$ & $\mathbf{2 5 i A}(60 \%)$ \\
\hline
\end{tabular}

${ }^{a}$ Yields were determined over two steps, starting from resin 23.

In these cases, the yields of the homoallylic amines 25 were determined after cleavage from the resin using a NaOMe solution. Again, the same trend in reactivity of the aromatic aldehydes was observed: electron rich aldehydes afforded the desired products 25 in high yields (entries 12,5 ), whereas electron poor ones produced a lower yield (entry 3), or no product at all (entry 4). 
Furthermore, the yields of these products were around $20 \%$ higher than those of the same products produced on the acid labile Wang linker system. ${ }^{2}$ This observation again substantiated the viability of the SEC linker for application to $N$-acyliminium ion chemistry.

Earlier, the introduction of aliphatic side chains in the solid phase one-pot three component $\mathrm{N}$-acyliminium ion reaction on the Wang resin proved to be troublesome. ${ }^{2}$ On the other hand, the introduction of aliphatic substituents in the solution phase reaction using acetals $\mathbf{1 6}$ did result in the efficient formation of the desired products. Therefore, the use of diethyl acetals in combination with SEC resin 23 was investigated (Table 7).

\section{Table 7}

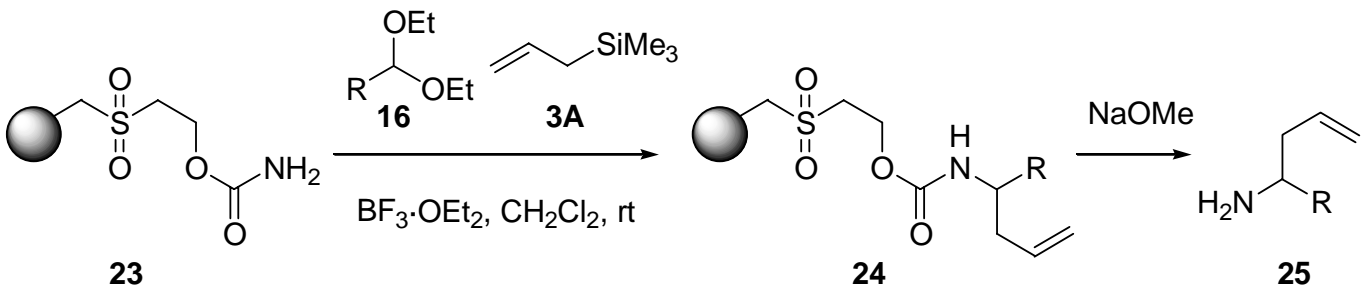

\begin{tabular}{|c|c|c|}
\hline Entry & $\mathrm{R}$ & Product (yield) ${ }^{a}$ \\
\hline 1 & $\mathrm{Bn}(\mathbf{1 6 f})$ & 25fA $(39 \%)$ \\
\hline 2 & n-hexyl (16g) & $25 g A(58 \%)$ \\
\hline 3 & cyclohexyl (16j) & $25 \mathbf{j A}(35 \%)$ \\
\hline 4 & $(16 \mathbf{k})$ & $25 \mathbf{k A}(46 \%)$ \\
\hline 5 & PhthN ${ }^{\prime} \xi \quad(16 h)$ & - \\
\hline 6 & $p-\mathrm{O}_{2} \mathrm{NC}_{6} \mathrm{H}_{4}(\mathbf{1 6 d})$ & $25 d A(7 \%)$ \\
\hline
\end{tabular}

${ }^{a}$ Yields were determined over two steps, starting from resin 23.

By using the aliphatic diethyl acetals 16f-g, j-k (entries 1-4), the corresponding products could indeed be obtained, albeit in moderate yields. Surprisingly, with acetal $\mathbf{1 6 h}$ in the solid phase reaction (entry 5) no product was obtained at all, whereas in solution phase (Scheme 3) the desired product was formed together with a substantial amount of the corresponding biscarbamate. Nevertheless, the successful introduction of aliphatic substituents (entries 1-4) significantly extended the scope of the process. Encouraged by these results, the application of the corresponding diethyl acetal functionality in the introduction of an electron poor aromatic substituent was also tested (entry 6). Unfortunately, the desired homoallylic amine 25dA was only formed in a low yield of $7 \%$.

In addition, the application of the different silyl nucleophiles 3G-J in combination with some aromatic aldehydes in the three component $\mathrm{N}$-acyliminium ion reaction was investigated (Table 8). 
Table 8

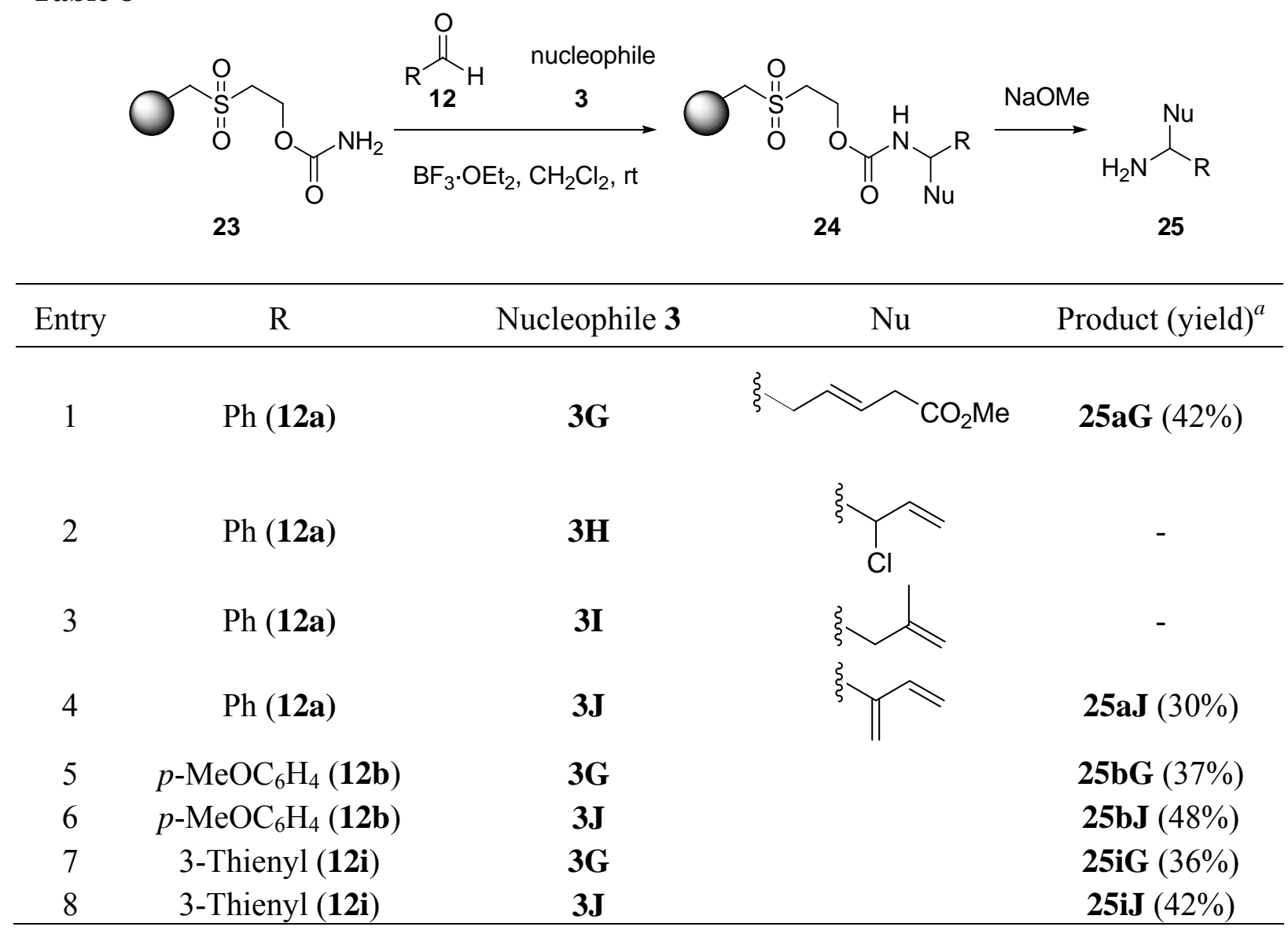

${ }^{a}$ Yields were determined over two steps, starting from resin 23.

By using the substituted allylsilanes 3G-I(entries 1-3), the 1-substituted silane 3G again afforded the corresponding product (42\%), while the 2- and 3-substituted allylsilanes $3 \mathbf{H}$-I were not reactive at all. A diene functionality could be introduced by making use of allenylsilane $\mathbf{3 J}$ (entry 4). Furthermore, silanes $\mathbf{3 G}$ and $\mathbf{3 J}$ were successfully used in combination with the aromatic aldehydes $\mathbf{1 2} \mathbf{b}$ and $\mathbf{1 2} \mathbf{i}$ (entries 5-8) to afford the corresponding homoallylic amines 25 in reasonable yields.

Finally, to extend the scope of the $N$-acyliminium ion reaction even more, the 'two-step' approach, involving the immobilized Bt-derivative $\mathbf{2 6}$ was applied (Table 9). The results show that the scope with respect to the nucleophile indeed could be extended in case of aromatic aldehydes (entries 2-3). Analogous to the solution phase reaction, CSA was used to generate the $\mathrm{N}$-acyliminium ion intermediate, while the aromatic nucleophile was used as the solvent. Moreover, the application of the Bt-derivative improved the yield of product 25dA to $36 \%$ over three steps (entry 4). Thus, the 'two-step' approach also extended the scope of the reaction with respect to electron poor aromatic aldehydes. 


\section{Table 9}

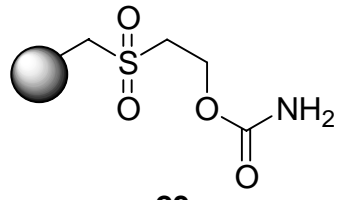

23<smiles>[R]C([N])N</smiles>

25

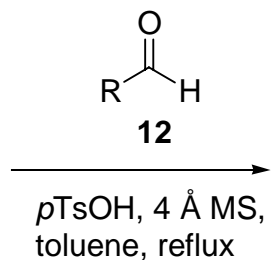

toluene, reflux

$\mathrm{THF} / \mathrm{MeOH}$

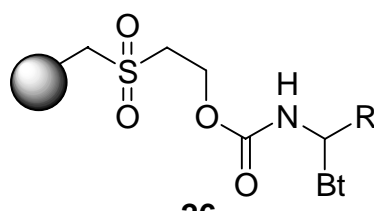

26

(Lewis) acid $\downarrow$ nucleophile $\mathbf{3}$

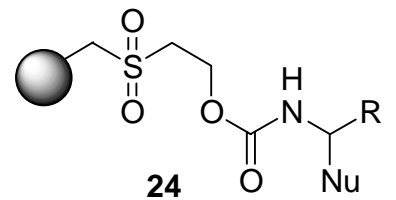

\begin{tabular}{|c|c|c|c|c|c|}
\hline Entry & $\mathrm{R}$ & Nucleophile 3 & Lewis Acid & $\mathrm{Nu}$ & Product (yield) ${ }^{a}$ \\
\hline 1 & $\mathrm{Ph}(\mathbf{1 2 a})$ & 3A & $\mathrm{BF}_{3} \cdot \mathrm{OEt}_{2}$ & & $25 a A(71 \%)$ \\
\hline 2 & $\mathrm{Ph}(\mathbf{1 2 a})$ & $3 \mathbf{M}$ & CSA & & $25 a M(50 \%)$ \\
\hline 3 & $\mathrm{Ph}(12 \mathbf{a})$ & $(3 N$ & CSA & & $25 a \mathbf{N}(20 \%)$ \\
\hline 5 & $p-\mathrm{O}_{2} \mathrm{NC}_{6} \mathrm{H}_{4}(12 \mathbf{a})$ & 3A & $\mathrm{BF}_{3} \cdot \mathrm{OEt}_{2}$ & & $25 d A(36 \%)$ \\
\hline
\end{tabular}

${ }^{a}$ Yields were determined over three steps, starting from resin 23.

If one compares the results of the solution phase $\mathrm{N}$-acyliminium ion reactions with those of the solid phase, a few interesting features appear. In general, the yields of the solid phase reactions are somewhat lower than the solution phase ones. For example, whereas the use of $p$ nitrobenzaldehyde (12d) in solution phase afforded the desired product in a reasonable yield, the same aldehyde on solid phase only produced a trace of the desired homoallylic amine. Although in the solution phase a similar trend in reactivity was observed, the low reactivity of aliphatic and electron poor aromatic substituents in the solid phase reactions was much more pronounced. This difference might be explained by the polarity of the environment in which the reactions take place: in solution phase, the cationic intermediates can be to some degree stabilized by the relatively polar solvent, while on solid phase the extent of stabilization is reduced as a result of the more apolar environment of the polymer support.

Furthermore, the use of diethyl acetal $\mathbf{1 6 h}$ in solution phase led to a considerable amount of the undesired bis-carbamate ( $c f .31$ in Scheme 5), while on the solid phase no such product was formed at all. Veenstra presumed the aforementioned bis-carbamate to be the intermediate, which was transformed into the key electrophile that then would undergo the nucleophilic attack 
$(30 \rightarrow 28)$. However, formation of such an intermediate in the solid phase reaction (31 in which $\mathrm{R}$ is attached to the polymeric backbone) would be unlikely if not impossible due to site-site isolation on the polymer. Therefore, most probably bis-carbamate $\mathbf{3 1}$ is formed as one of the intermediate species, but is not necessarily required for the formation of product $\mathbf{2 8}$.

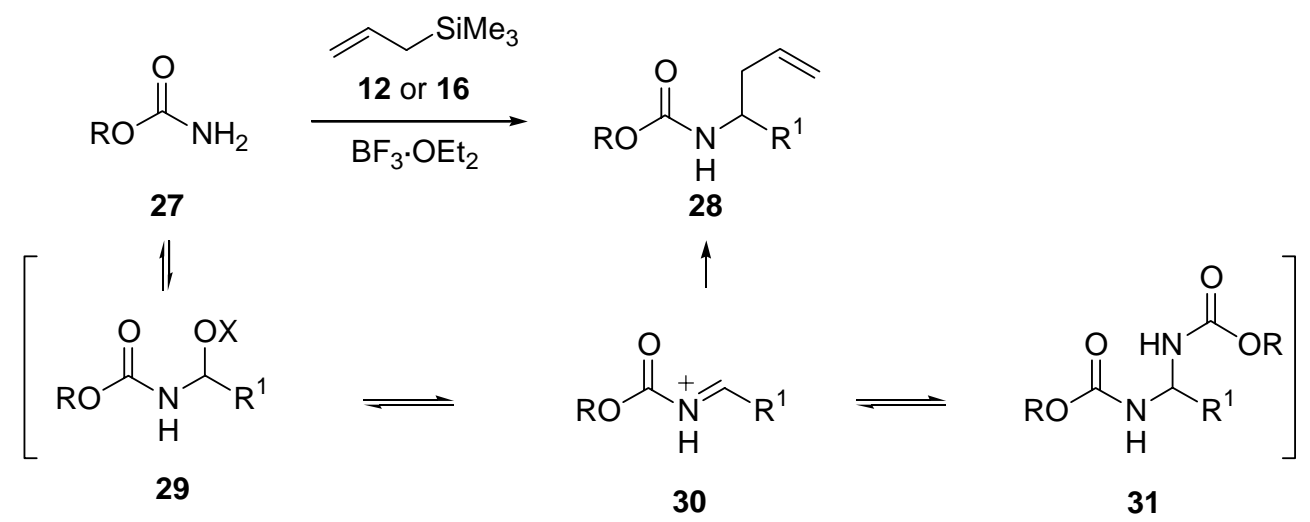

\section{Scheme 5}

In conclusion, the scope and limitations of the one-pot three component $N$-acyliminium ion reaction have been explored. In both the solution and solid phase reactions a similar trend can be observed. With respect to the aldehyde component, the best yields were obtained with electron rich aromatic ones. Whereas aliphatic side chains could be introduced in satisfactory yields by using the corresponding diethyl acetals, electron poor aromatic substituents could not efficiently be introduced by using the three component $N$-acyliminium ion reaction. However, a 'two-step' approach involving a Bt-derivative has led to an extension of the scope to also include electron poor aromatic groups. With respect to the nucleophile, the scope was mainly restricted to simple substituted allylsilanes. A useful addition of potential nucleophiles was found in the application of 2,3-butadienylsilane. Furthermore, aromatic nucleophiles were used in the 'two-step' approach. Overall, it can be concluded that a diverse range of products was made, although the introduction of different structural classes required its own optimization, which has led to a range of optimal reaction conditions.

\section{Experimental Section}

General Procedures. All reactions with air or moisture sensitive reagents were carried out under an inert atmosphere of dry nitrogen. Standard syringe techniques were applied for the transfer of air or moisture sensitive reagents and dry solvents. The solid phase reactions were gently stirred with a magnetic stirring bar. The resins were washed according to the indicated sequence and dried in vacuo $\left(50^{\circ} \mathrm{C}\right)$ prior to use. The resin was allowed to swell/shrink for at least 1 minute before each filtration. Infrared (IR) spectra were obtained from $\mathrm{KBr}$ pellets or neat, using a Bruker IFS 28FT-spectrometer with wavelengths $(v)$ reported in $\mathrm{cm}^{-1}$. IR spectra of resins were 
measured in $\mathrm{KBr}$ using a DRIFT module. Proton nuclear magnetic resonance $\left({ }^{1} \mathrm{H}\right.$ NMR) spectra were determined in the indicated solvent using a Bruker AC 200 (200 MHz), Bruker ARX 400 (400 MHz), or a Varian Inova (500 MHz) spectrometer. The machines were also used for carbon nuclear magnetic resonance $\left({ }^{13} \mathrm{C} \mathrm{NMR}\right.$, APT) spectra $(50 \mathrm{MHz}, 100 \mathrm{MHz}$ and $125 \mathrm{MHz}$ respectively). Chemical shifts $(\delta)$ are given in ppm downfield from tetramethylsilane. Mass spectra and accurate mass measurements were carried out using a JEOL JMS-SX/SX 102A Tandem Mass spectrometer. Elemental analysis were performed by Dornis u. Kolbe Mikroanalytisches Laboratorium, Mülheim a. d. Ruhr, Germany. $R_{f}$ values were obtained by using thin layer chromatography (TLC) on silica gel-coated plastic sheets (Merck silica gel 60 $\mathrm{F}_{254}$ ) with the indicated solvent (mixture). UV light or $\mathrm{I}_{2}$ were used as visualizing agents, while $\mathrm{KMnO}_{4}$ solution and heat or anisaldehyde solution and heat were used as developing agents. Chromatographic purification refers to flash column chromatography using the indicated solvent (mixture) and Acros Organics Silica gel (0.035-0.070 nm). Melting points are uncorrected and were determined on a Büchi melting point B-545 apparatus. Dry THF and $\mathrm{Et}_{2} \mathrm{O}$ were freshly distilled from sodium benzophenone ketyl. Dry DMF, $\mathrm{CH}_{2} \mathrm{Cl}_{2}$, EtOAc and $\mathrm{MeCN}$ were distilled from $\mathrm{CaH}_{2}$ and stored over $4 \AA$ MS under a dry nitrogen atmosphere. PE (60-80) was distilled prior to use. Merrifield resin (200-400 mesh, 1\% DVB, $1.7 \mathrm{mmol} \mathrm{Cl} / \mathrm{g}$ ) and Wang resin (200-400 mesh, $1 \% \mathrm{DVB}, 0.71 \mathrm{mmol} \mathrm{OH} / \mathrm{g}$ ) were obtained from Fluka. All commercially available reagents were used as received, unless indicated otherwise.

2-Benzylthioethanol (6). ${ }^{26}$ Benzyl bromide $(7.21 \mathrm{~mL}, 42.7 \mathrm{mmol})$, and $\mathrm{Cs}_{2} \mathrm{CO}_{3}(14.6 \mathrm{~g}, 44.9$ mmol) were suspended in dry DMF $(150 \mathrm{~mL})$, mercaptoethanol $(25.0 \mathrm{~mL}, 44.9 \mathrm{mmol})$ was added dropwise and the reaction mixture was stirred for $4 \mathrm{~h}$ at $60^{\circ} \mathrm{C}$ and then for $20 \mathrm{~h}$ at rt. Then, saturated aqueous $\mathrm{NH}_{4} \mathrm{Cl}(100 \mathrm{ml})$ was added and the layers were separated. The aqueous layer was extracted with $\mathrm{CH}_{3} \mathrm{CCl}_{3}(2 \times 75 \mathrm{~mL})$, the combined organic layers were washed with aqueous saturated $\mathrm{NaCl}(75 \mathrm{~mL})$, dried $\left(\mathrm{MgSO}_{4}\right)$ and concentrated in vacuo to obtain 6 (7.23 g, $40.2 \mathrm{mmol}, 94 \%$ ) as a colorless oil, which was used without any further purification. ${ }^{1} \mathrm{H}$ NMR $\left(200 \mathrm{MHz}, \mathrm{CDCl}_{3}\right) \delta$ 7.34-7.27 (m, 5H, Ar-H), $3.72\left(\mathrm{~s}, 2 \mathrm{H}, \mathrm{ArCH}_{2}\right), 3.64(\mathrm{t}, J=6.1 \mathrm{~Hz}, 2 \mathrm{H}$, $\left.\mathrm{OCH}_{2}\right), 2.62\left(\mathrm{t}, J=6.0 \mathrm{~Hz}, 2 \mathrm{H}, \mathrm{SCH}_{2}\right) .{ }^{13} \mathrm{C} \mathrm{NMR}\left(50 \mathrm{MHz}, \mathrm{CDCl}_{3}\right) \delta 137.9,128.6,128.4,126.9$ (Ar-C), $60.1\left(\mathrm{OCH}_{2}\right), 35.6,34.1\left(\mathrm{ArCH}_{2}\right.$ and $\left.\mathrm{SCH}_{2}\right) . \mathrm{IR} v, \mathrm{~cm}^{-1} 3490,3030,2920,1410,1335$, 1070 .

2-Benzylsulfonylethanol (7). To a solution of thioether 6 (7.69 g, $42.7 \mathrm{mmol})$ in $\mathrm{CH}_{2} \mathrm{Cl}_{2}$ $(100 \mathrm{~mL}), \mathrm{mCPBA}(77 \%, 22.1 \mathrm{~g}, 98.2 \mathrm{mmol})$ was added in portions at $0{ }^{\circ} \mathrm{C}$. When addition was complete the mixture was stirred for $18 \mathrm{~h}$ at rt. Then, saturated aqueous $\mathrm{NaHCO}_{3}(100 \mathrm{~mL})$ was added and the layers were separated. The aqueous layer was extracted with $\mathrm{CH}_{2} \mathrm{Cl}_{2}(2 \times 50 \mathrm{~mL})$, the combined organic layers were washed with aqueous saturated $\mathrm{NaCl}(50 \mathrm{~mL})$, dried $\left(\mathrm{MgSO}_{4}\right)$ and concentrated in vacuo. The crude product was purified using column chromatography (EtOAc/PE 1:1) to afford $7(8.41 \mathrm{~g}, 0.40 \mathrm{mmol}, 93 \%)$ as a white solid. ${ }^{1} \mathrm{H}$ NMR (400 MHz, $\left.\mathrm{CDCl}_{3}\right) \delta$ 7.45-7.33 (m, 5H, Ar-H), $4.35\left(\mathrm{~s}, 2 \mathrm{H}, \mathrm{ArCH}_{2}\right), 4.06\left(\mathrm{~d}, J=5.3 \mathrm{~Hz}, 2 \mathrm{H}, \mathrm{OCH}_{2}\right), 3.08(\mathrm{~d}$, $\left.J=5.3 \mathrm{~Hz}, 2 \mathrm{H}, \mathrm{SO}_{2} \mathrm{CH}_{2}\right) .{ }^{13} \mathrm{C} \mathrm{NMR}\left(100 \mathrm{MHz}, \mathrm{CDCl}_{3}\right) \delta 130.9,129.1,129.0,127.8$ (Ar-C), 
$61.1\left(\mathrm{ArCH}_{2}\right), 56.3\left(\mathrm{OCH}_{2}\right), 53.0\left(\mathrm{SO}_{2} \mathrm{CH}_{2}\right) . \mathrm{IR} v, \mathrm{~cm}^{-1} 3488,3033,2978,1495,1393,1287$, 1117, 1070, 843. HRMS (EI+) calculated for $\mathrm{C}_{9} \mathrm{H}_{12} \mathrm{O}_{3} \mathrm{~S}\left(\mathrm{M}^{+}\right)$200.0507, found 200.0514.

2-(Benzylsulfonyl)ethyl carbamate (8). Alcohol 7 (7.00 g, $33.0 \mathrm{mmol}$ ) was dissolved in $\mathrm{CH}_{2} \mathrm{Cl}_{2}$ $(70 \mathrm{~mL})$ and cooled to $0{ }^{\circ} \mathrm{C}$, 4-nitrophenyl chloroformate $(6.66 \mathrm{~g}, 33.0 \mathrm{mmol})$ and $\mathrm{N}$ methylmorpholine $(3.63 \mathrm{~mL}, 33.0 \mathrm{mmol})$ were added, the reaction mixture was allowed to warm up to $\mathrm{rt}$ and was stirred for $18 \mathrm{~h}$ at this temperature. Then, saturated aqueous $\mathrm{NH}_{4} \mathrm{Cl}(50 \mathrm{~mL})$ was added and the layers were separated. The aqueous layer was extracted with $\mathrm{CH}_{2} \mathrm{Cl}_{2}(2 \times 50 \mathrm{~mL})$, the combined organic layers were washed with aqueous saturated $\mathrm{NaCl}(50 \mathrm{~mL})$, dried $\left(\mathrm{MgSO}_{4}\right)$ and concentrated in vacuo. The crude carbonate was dissolved in DMF (60 mL), a saturated $\mathrm{NH}_{3} / \mathrm{MeOH}$ solution $(30 \mathrm{ml})$ was added and the reaction mixture turned yellow immediately. The reaction mixture was stirred for $18 \mathrm{~h}$ at $\mathrm{rt}$ and concentrated in vacuo. The crude product was purified using column chromatography (EtOAc/PE 1:1) to afford 8 (7.14 g, $29.4 \mathrm{mmol}, 89 \%)$ as a white solid. Mp 173-175 ${ }^{\circ} \mathrm{C} . R_{f} 0.15$ (EtOAc/PE 1:1). ${ }^{1} \mathrm{H}$ NMR (400 MHz, $\left.\mathrm{CDCl}_{3}\right) \delta$ 7.37-7.34 (m, 5H, Ar-H), 5.36 (br s, 2H, NH$\left.)_{2}\right), 4.43\left(\mathrm{t}, J=5.8 \mathrm{~Hz}, 2 \mathrm{H}, \mathrm{OCH}_{2}\right), 4.26\left(\mathrm{~s}, 2 \mathrm{H}, \mathrm{ArCH}_{2}\right), 3.15$ $\left(\mathrm{t}, J=5.8 \mathrm{~Hz}, 2 \mathrm{H}, \mathrm{SO}_{2} \mathrm{CH}_{2}\right) .{ }^{13} \mathrm{C} \mathrm{NMR}\left(100 \mathrm{MHz}, \mathrm{CDCl}_{3}\right) \delta 156.3$ (OCON), 130.7, 129.0, 128.9, 127.4 (Ar-C), $60.6\left(\mathrm{OCH}_{2}\right), 57.8\left(\mathrm{ArCH}_{2}\right), 50.6\left(\mathrm{SO}_{2} \mathrm{CH}_{2}\right) . \mathrm{IR} v, \mathrm{~cm}^{-1} 3421,3033,2984,1680$, $1427,1365,1282,1119,1025,995$.

2-(Benzylthio)ethyl carbamate (9). Alcohol 6 (4.61 g, $25.6 \mathrm{mmol}$ ) was dissolved in $\mathrm{CH}_{2} \mathrm{Cl}_{2}$ $(40 \mathrm{~mL})$ and cooled to $0{ }^{\circ} \mathrm{C}$, 4-nitrophenyl chloroformate $(5.16 \mathrm{~g}, 25.6 \mathrm{mmol})$ and $\mathrm{N}$ methylmorpholine $(2.81 \mathrm{~mL}, 25.6 \mathrm{mmol})$ were added, the reaction mixture was allowed to warm up to $\mathrm{rt}$ and was stirred for $18 \mathrm{~h}$ at this temperature. Then, saturated aqueous $\mathrm{NH}_{4} \mathrm{Cl}(30 \mathrm{~mL})$ was added and the layers were separated. The aqueous layer was extracted with $\mathrm{CH}_{2} \mathrm{Cl}_{2}(2 \times 30 \mathrm{~mL})$, the combined organic layers were washed with aqueous saturated $\mathrm{NaCl}(30 \mathrm{~mL})$, dried $\left(\mathrm{MgSO}_{4}\right)$ and concentrated in vacuo. The crude carbonate was dissolved in DMF (40 mL), a saturated $\mathrm{NH}_{3} / \mathrm{MeOH}$ solution $(20 \mathrm{~mL})$ was added and the reaction mixture turned yellow immediately. The reaction mixture was stirred for $18 \mathrm{~h}$ at $\mathrm{rt}$ and concentrated in vacuo. The crude product was purified using column chromatography (EtOAc/PE 1:1) to afford 9 (4.38 g, $20.7 \mathrm{mmol}, 81 \%)$ as a white solid. $R_{f} 0.19$ (EtOAc/PE 1:1). ${ }^{1} \mathrm{H} \mathrm{NMR}\left(400 \mathrm{MHz}, \mathrm{CDCl}_{3}\right) \delta$ 7.36-7.23 (m, 5H, Ar-H), 4.77 (br s, 2H, NH$), 4.17\left(\mathrm{t}, J=6.8 \mathrm{~Hz}, 2 \mathrm{H}, \mathrm{OCH}_{2}\right), 3.75\left(\mathrm{~s}, 2 \mathrm{H}, \mathrm{ArCH}_{2}\right), 2.64(\mathrm{t}, J=6.8 \mathrm{~Hz}$, $\left.2 \mathrm{H}, \mathrm{SCH}_{2}\right) .{ }^{13} \mathrm{C} \mathrm{NMR}\left(100 \mathrm{MHz}, \mathrm{CDCl}_{3}\right) \delta 156.5(\mathrm{OCON}), 137.9,128.8,128.1,127.0$ (Ar-C), $63.6\left(\mathrm{OCH}_{2}\right), 36.2\left(\mathrm{ArCH}_{2}\right), 29.9\left(\mathrm{SCH}_{2}\right) . \mathrm{IR} v, \mathrm{~cm}^{-1} 3497,3353,3028,2919,1744,1601,1454$, $1404,1337,1072$.

\section{General procedure A for the three component reaction with carbamates 8-10 and 14}

The carbamate, aldehyde ( 1 equiv) and nucleophile ( 1 equiv) were dissolved in $\mathrm{CH}_{2} \mathrm{Cl}_{2}$. The Lewis acid ( 1 equiv) was added and the reaction mixture was stirred for the indicated time at rt. Then, saturated aqueous $\mathrm{NaHCO}_{3}$ was added and the layers were separated. The aqueous layer was extracted with $\mathrm{CH}_{2} \mathrm{Cl}_{2}(2 \times)$, the combined organic layers were washed with aqueous saturated $\mathrm{NaCl}$, dried $\left(\mathrm{MgSO}_{4}\right)$ and concentrated in vacuo. The crude product was purified using column chromatography (EtOAc/PE). 
(1-Phenylbut-3-enyl)carbamic acid allyl ester (13aA). Allyl carbamate 11 (100 mg, 0.99 mmol), benzaldehyde $(101 \mu \mathrm{L}, 0.99 \mathrm{mmol})$ allyltrimethylsilane $(157 \mu \mathrm{L}, 0.99 \mathrm{mmol})$ and $\mathrm{BF}_{3} \cdot \mathrm{OEt}_{2}$ $(125 \mu \mathrm{L}, 0.99 \mathrm{mmol})$ in $\mathrm{CH}_{2} \mathrm{Cl}_{2}(2 \mathrm{~mL})$ were reacted for $3 \mathrm{~h}$ according to general procedure A to afford 13aA (188 mg, $0.82 \mathrm{mmol}, 82 \%)$ as a colorless oil. $R_{f} 0.59$ (EtOAc/PE 1:2). ${ }^{1} \mathrm{H}$ NMR $\left(200 \mathrm{MHz}, \mathrm{CDCl}_{3}\right) \delta$ 7.45-7.10 (m, 5H, Ar-H), 6.05-5.55 (m, 2H, $\left.2 \times \mathrm{CH}=\mathrm{CH}_{2}\right), 5.40-4.95(\mathrm{~m}$, $\left.4 \mathrm{H}, 2 \times \mathrm{CH}=\mathrm{CH}_{2}\right), 4.90-4.70(\mathrm{~m}, 1 \mathrm{H}, \mathrm{NHCH}), 4.55\left(\mathrm{dd}, J=1.1,5.6 \mathrm{~Hz}, 2 \mathrm{H}, \mathrm{OCH}_{2}\right), 2.56-2.53$ $\left(\mathrm{m}, 2 \mathrm{H}, \mathrm{CH}_{2} \mathrm{CH}=\mathrm{CH}_{2}\right) .{ }^{13} \mathrm{C} \mathrm{NMR}\left(100 \mathrm{MHz}, \mathrm{CDCl}_{3}\right) \delta 155.3$ (OCON), 141.9 (Ar-C), 133.7, $132.8\left(2 \times \mathrm{CH}=\mathrm{CH}_{2}\right), 128.4,127.4,126.1(\mathrm{Ar}-\mathrm{C}), 118.2,117.6\left(2 \times \mathrm{CH}=\mathrm{CH}_{2}\right), 65.5\left(\mathrm{OCH}_{2}\right)$, $54.4(\mathrm{NHCH}), 40.9\left(\mathrm{CH}_{2} \mathrm{CH}=\mathrm{CH}_{2}\right)$. IR $v, \mathrm{~cm}^{-1} 3326,3069,3029,2979,2937,1713,1537,1252$, 1041, 1041, 994, 919. HRMS (FAB+) calculated for $\mathrm{C}_{14} \mathrm{H}_{18} \mathrm{NO}_{2}\left(\mathrm{M}^{+}+\mathrm{H}\right)$ 232.1338, found 232.1339 .

[1-(4-Methoxyphenyl)but-3-enyl]carbamic acid allyl ester (13bA). Allyl carbamate 11 (100 mg, $0.99 \mathrm{mmol})$, 4-methoxybenzaldehyde $(120 \mu \mathrm{L}, 0.99 \mathrm{mmol})$ allyltrimethylsilane $(157 \mu \mathrm{L}, 0.99 \mathrm{mmol})$ and $\mathrm{BF}_{3} \cdot \mathrm{OEt}_{2}(125 \mu \mathrm{L}, 0.99 \mathrm{mmol})$ in $\mathrm{CH}_{2} \mathrm{Cl}_{2}(2 \mathrm{~mL})$ were reacted for $3 \mathrm{~h}$ according to general procedure A to afford 13bA $(207 \mathrm{mg}, 0.79 \mathrm{mmol}, 80 \%)$ as a colorless oil. $R_{f} 0.48$ (EtOAc/PE 1:2). ${ }^{1} \mathrm{H}$ NMR $\left(200 \mathrm{MHz}, \mathrm{CDCl}_{3}\right) \delta$ 7.25-7.10 (m, 2H, Ar-H), 7.00-6.80 (m, $2 \mathrm{H}, \mathrm{Ar}-\mathrm{H}), 6.05-5.55\left(\mathrm{~m}, 2 \mathrm{H}, 2 \times \mathrm{CH}=\mathrm{CH}_{2}\right), 5.40-4.85\left(\mathrm{~m}, 4 \mathrm{H}, 2 \times \mathrm{CH}=\mathrm{CH}_{2}\right), 4.82-4.65(\mathrm{~m}, 1 \mathrm{H}$, $\mathrm{NHCH}), 4.55\left(\mathrm{dd}, J=1.1,4.6 \mathrm{~Hz}, 2 \mathrm{H}, \mathrm{OCH}_{2}\right), 3.80(\mathrm{~s}, 3 \mathrm{H}, \mathrm{OMe}), 2.56-2.52(\mathrm{~m}, 2 \mathrm{H}$, $\left.\mathrm{CH}_{2} \mathrm{CH}=\mathrm{CH}_{2}\right) .{ }^{13} \mathrm{C} \mathrm{NMR}\left(100 \mathrm{MHz}, \mathrm{CDCl}_{3}\right) \delta 156.7(\mathrm{Ar}-\mathrm{C}), 155.4(\mathrm{OCON}), 134.0,133.9(2 \times$ $\left.\mathrm{CH}=\mathrm{CH}_{2}\right), 127.3(\mathrm{Ar}-\mathrm{C}), 118.0,117.5\left(2 \times \mathrm{CH}=\mathrm{CH}_{2}\right), 113.8(\mathrm{Ar}-\mathrm{C}), 65.4\left(\mathrm{OCH}_{2}\right), 55.2,53.9$ ( $\mathrm{NHCH}$ and $\mathrm{OMe}), 40.9,40.4\left(2 \times \mathrm{CH}_{2} \mathrm{CH}=\mathrm{CH}_{2}\right)$. IR $v, \mathrm{~cm}^{-1} 3306,3076,2999,2937,1712$, 1513, 1246, 1179, 1037, 995, 920. HRMS (FAB+) calculated for $\mathrm{C}_{15} \mathrm{H}_{20} \mathrm{NO}_{3}\left(\mathrm{M}^{+}+\mathrm{H}\right) 262.1443$, found 262.1439 .

[1-(4-Cyanophenyl)but-3-enyl]carbamic acid allyl ester (13cA). Allyl carbamate 11 (100 mg, $0.99 \mathrm{mmol})$, 4-cyanobenzaldehyde $(112 \mathrm{mg}, 0.99 \mathrm{mmol})$ allyltrimethylsilane (157 $\mu \mathrm{L}$, $0.99 \mathrm{mmol})$ and $\mathrm{BF}_{3} \cdot \mathrm{OEt}_{2}(125 \mu \mathrm{L}, 0.99 \mathrm{mmol})$ in $\mathrm{CH}_{2} \mathrm{Cl}_{2}(2 \mathrm{~mL})$ were reacted for $20 \mathrm{~h}$ according to general procedure A to afford 13cA $(114 \mathrm{mg}, 0.45 \mathrm{mmol}, 45 \%)$ as a colorless oil. $R_{f}$ 0.44 (EtOAc/PE 1:2). ${ }^{1} \mathrm{H}$ NMR (200 MHz, $\left.\mathrm{CDCl}_{3}\right) \delta 7.63$ (d, $\left.J=8.3 \mathrm{~Hz}, 2 \mathrm{H}, \mathrm{Ar}-\mathrm{H}\right), 7.38$ (d, $J=$ $8.2 \mathrm{~Hz}, 2 \mathrm{H}, \mathrm{Ar}-\mathrm{H}), 6.00-5.50\left(\mathrm{~m}, 2 \mathrm{H}, 2 \times \mathrm{CH}=\mathrm{CH}_{2}\right), 5.40-5.00\left(\mathrm{~m}, 4 \mathrm{H}, 2 \times \mathrm{CH}=\mathrm{CH}_{2}\right), 4.80$ (dd, $J=6.6,13.2 \mathrm{~Hz}, 1 \mathrm{H}, \mathrm{NHCH}), 4.53\left(\mathrm{~d}, J=5.6 \mathrm{~Hz}, 2 \mathrm{H}, \mathrm{OCH}_{2}\right), 2.65-2.30\left(\mathrm{~m}, 2 \mathrm{H}, \mathrm{CH}_{2} \mathrm{CH}=\mathrm{CH}_{2}\right)$. ${ }^{13} \mathrm{C} \mathrm{NMR}\left(100 \mathrm{MHz}, \mathrm{CDCl}_{3}\right) \delta 155.2(\mathrm{OCON}), 147.5,132.3,132.2,126.9,126.7$ (Ar-C and $2 \times$ $\left.\mathrm{CH}=\mathrm{CH}_{2}\right), 119.3,118.5,117.8,111.0\left(\mathrm{Ar}-\mathrm{C}, \mathrm{CN}\right.$ and $\left.2 \times \mathrm{CH}=\mathrm{CH}_{2}\right), 65.7\left(\mathrm{OCH}_{2}\right), 54.0(\mathrm{NHCH})$, $40.5\left(\mathrm{CH}_{2} \mathrm{CH}=\mathrm{CH}_{2}\right)$. IR $v, \mathrm{~cm}^{-1} 3336,3077,2983,2229,1704,1530,1251,1041,923$. HRMS $(\mathrm{FAB}+)$ calculated for $\mathrm{C}_{15} \mathrm{H}_{17} \mathrm{~N}_{2} \mathrm{O}_{2}\left(\mathrm{M}^{+}+\mathrm{H}\right)$ 257.1290, found 257.1276.

[1-(4-Nitrophenyl)but-3-enyl]carbamic acid allyl ester (13dA). Allyl carbamate 11 (100 mg, $0.99 \mathrm{mmol})$, 4-nitrobenzaldehyde (132 mg, $0.99 \mathrm{mmol})$ allyltrimethylsilane (157 $\mu \mathrm{L}, 0.99 \mathrm{mmol})$ and $\mathrm{BF}_{3} \cdot \mathrm{OEt}_{2}(125 \mu \mathrm{L}, 0.99 \mathrm{mmol})$ in $\mathrm{CH}_{2} \mathrm{Cl}_{2}(2 \mathrm{~mL})$ were reacted for $20 \mathrm{~h}$ according to general procedure A to afford 13dA (109 $\mathrm{mg}, 0.40 \mathrm{mmol}, 40 \%)$ as a colorless oil. $R_{f} 0.48$ (EtOAc/PE 1:2). ${ }^{1} \mathrm{H}$ NMR $\left(200 \mathrm{MHz}, \mathrm{CDCl}_{3}\right) \delta 8.21(\mathrm{~d}, J=7.2 \mathrm{~Hz}, 2 \mathrm{H}, \mathrm{Ar}-\mathrm{H}), 7.45(\mathrm{~d}, J=7.0 \mathrm{~Hz}, 2 \mathrm{H}, \mathrm{Ar}-$ $\mathrm{H}), 6.00-5.50\left(\mathrm{~m}, 2 \mathrm{H}, 2 \times \mathrm{CH}=\mathrm{CH}_{2}\right), 5.40-5.05\left(\mathrm{~m}, 4 \mathrm{H}, 2 \times \mathrm{CH}=\mathrm{CH}_{2}\right), 4.86(\mathrm{t}, J 6.6 \mathrm{~Hz}, 1 \mathrm{H}$, 
$\mathrm{NHCH}), 4.53\left(\mathrm{~d}, J=5.6 \mathrm{~Hz}, 2 \mathrm{H}, \mathrm{OCH}_{2}\right), 2.65-2.45\left(\mathrm{~m}, 2 \mathrm{H}, \mathrm{CH}_{2} \mathrm{CH}=\mathrm{CH}_{2}\right) .{ }^{13} \mathrm{C} \mathrm{NMR}(100 \mathrm{MHz}$, $\left.\mathrm{CDCl}_{3}\right) 155.4(\mathrm{OCON}), 147.0,132.6,132.4,127.0,126.3,123.7$ (Ar-C), 119.3, $117.8(2 \times$ $\left.\mathrm{CH}=\mathrm{CH}_{2}\right), 65.7\left(\mathrm{OCH}_{2}\right), 54.1(\mathrm{NHCH}), 40.5\left(\mathrm{CH}_{2} \mathrm{CH}=\mathrm{CH}_{2}\right) . \mathrm{IR} v, \mathrm{~cm}^{-1} 3543,3332,3015,2975$, $1721,1608,1558,1442,1265,1112,1046,931$. HRMS (FAB+) calculated for $\mathrm{C}_{14} \mathrm{H}_{17} \mathrm{~N}_{2} \mathrm{O}_{4}\left(\mathrm{M}^{+}\right.$ + H) 277.1188 , found 277.1190 .

(1-Isopropylbut-3-enyl)carbamic acid allyl ester (13eA). Allyl carbamate 11 (100 mg, $0.99 \mathrm{mmol})$, isobutyraldehyde $(90 \mu \mathrm{L}, 0.99 \mathrm{mmol})$ allyltrimethylsilane $(157 \mu \mathrm{L}, 0.99 \mathrm{mmol})$ and $\mathrm{BF}_{3} \cdot \mathrm{OEt}_{2}(125 \mu \mathrm{L}, 0.99 \mathrm{mmol})$ in $\mathrm{CH}_{2} \mathrm{Cl}_{2}(2 \mathrm{~mL})$ were reacted for $20 \mathrm{~h}$ according to general procedure A to afford 13eA (89 mg, $0.44 \mathrm{mmol}, 44 \%)$ as a colorless oil. $R_{f} 0.64$ (EtOAc/PE 1:2). ${ }^{1} \mathrm{H}$ NMR $\left(200 \mathrm{MHz}, \mathrm{CDCl}_{3}\right) \delta 6.05-5.60\left(\mathrm{~m}, 2 \mathrm{H}, 2 \times \mathrm{CH}=\mathrm{CH}_{2}\right), 5.40-4.95(\mathrm{~m}, 4 \mathrm{H}, 2 \times$ $\left.\mathrm{CH}=\mathrm{CH}_{2}\right), 4.60-4.45\left(\mathrm{~d}, J=5.2 \mathrm{~Hz}, 2 \mathrm{H}, \mathrm{OCH}_{2}\right), 3.65-3.45(\mathrm{~m}, 1 \mathrm{H}, \mathrm{NHCH}), 2.40-2.00(\mathrm{~m}, 2 \mathrm{H}$, $\left.\mathrm{CH}_{2} \mathrm{CH}=\mathrm{CH}_{2}\right), 1.85-1.60\left(\mathrm{~m}, 1 \mathrm{H}, \mathrm{CH}\left(\mathrm{CH}_{3}\right)_{2}\right), 1.00-0.70\left(\mathrm{~m}, 6 \mathrm{H}, \mathrm{CH}\left(\mathrm{CH}_{3}\right)_{2}\right) .{ }^{13} \mathrm{C} \mathrm{NMR}(125$ $\left.\mathrm{MHz}, \mathrm{CDCl}_{3}\right) \delta 153.6(\mathrm{OCON}), 134.7,133.0\left(2 \times \mathrm{CH}=\mathrm{CH}_{2}\right), 122.0,117.3\left(2 \times \mathrm{CH}=\mathrm{CH}_{2}\right), 67.0$ $\left(\mathrm{OCH}_{2}\right), 55.6(\mathrm{NHCH}), 36.8\left(\mathrm{CH}_{2} \mathrm{CH}=\mathrm{CH}_{2}\right), 31.4\left(\mathrm{CH}\left(\mathrm{CH}_{3}\right)_{2}\right), 19.2\left(\mathrm{CH}\left(\mathrm{CH}_{3}\right)_{2}\right) . \mathrm{IR} v, \mathrm{~cm}^{-1}$ $3323,3076,2960,1720,1647,1536,1250,993$. HRMS (FAB+) calculated for $\mathrm{C}_{11} \mathrm{H}_{20} \mathrm{NO}_{2}\left(\mathrm{M}^{+}+\right.$ H) 198.1494, found 298.1492.

(1-Benzylbut-3-enyl)carbamic acid allyl ester (13fA). Allyl carbamate 11 (100 mg, $0.99 \mathrm{mmol})$, phenylacetaldehyde diethyl acetal $(163 \mu \mathrm{L}, 0.99 \mathrm{mmol})$ allyltrimethylsilane $(157 \mu \mathrm{L}, 0.99 \mathrm{mmol})$ and $\mathrm{BF}_{3} \cdot \mathrm{OEt}_{2}(125 \mu \mathrm{L}, 0.99 \mathrm{mmol})$ in $\mathrm{CH}_{2} \mathrm{Cl}_{2}(2 \mathrm{~mL})$ were reacted for 20 $\mathrm{h}$ according to general procedure A to afford 13fA (182 $\mathrm{mg}, 0.74 \mathrm{mmol}, 75 \%)$ as a colorless oil. $R_{f} 0.58$ (EtOAc/PE 1:2). ${ }^{1} \mathrm{H}$ NMR $\left(200 \mathrm{MHz}, \mathrm{CDCl}_{3}\right) \delta$ 7.40-7.10 (m, 5H, Ar-H), 6.00-5.70 (m, $\left.2 \mathrm{H}, 2 \times \mathrm{CH}=\mathrm{CH}_{2}\right), 5.40-5.00\left(\mathrm{~m}, 4 \mathrm{H}, 2 \times \mathrm{CH}=\mathrm{CH}_{2}\right), 4.65-4.45\left(\mathrm{~m}, 2 \mathrm{H}, \mathrm{OCH}_{2}\right), 3.97(\mathrm{dd}, J=$ 6.9, $13.7 \mathrm{~Hz}, 1 \mathrm{H}, \mathrm{NHCH}), 2.90-2.70\left(\mathrm{~m}, 2 \mathrm{H}, \mathrm{ArCH}_{2}\right), 2.40-2.05\left(\mathrm{~m}, 2 \mathrm{H}, \mathrm{CH}_{2} \mathrm{CH}=\mathrm{CH}_{2}\right) .{ }^{13} \mathrm{C}$ NMR $\left(100 \mathrm{MHz}, \mathrm{CDCl}_{3}\right) \delta 137.8(\mathrm{Ar}-\mathrm{C}), 134.1,132.9\left(2 \times \mathrm{CH}=\mathrm{CH}_{2}\right), 139.3,128.3,126.3(\mathrm{Ar}-$ C), 118.0, $117.3\left(2 \times \mathrm{CH}=\mathrm{CH}_{2}\right), 65.3\left(\mathrm{OCH}_{2}\right), 53.2(\mathrm{NHCH}), 40.3,38.0\left(\mathrm{ArCH}_{2}\right.$ and $\left.\mathrm{CH}_{2} \mathrm{CH}=\mathrm{CH}_{2}\right)$. IR $v, \mathrm{~cm}^{-1} 3334,3027,2925,1718,1531,1256,1121,1043,994,918$. HRMS $(\mathrm{FAB}+)$ calculated for $\mathrm{C}_{15} \mathrm{H}_{20} \mathrm{NO}_{2}\left(\mathrm{M}^{+}+\mathrm{H}\right)$ 246.1494, found 246.1483.

(1-Benzylbut-3-enyl)carbamic acid allyl ester (13aB). Allyl carbamate 11 (100 mg, 0.99 mmol), benzaldehyde (101 $\mu \mathrm{L}, 0.99 \mathrm{mmol})$ 2-(chloromethyl)allyltrimethylsilane (179 $\mu \mathrm{L}, 0.99 \mathrm{mmol})$ and $\mathrm{BF}_{3} \cdot \mathrm{OEt}_{2}(125 \mu \mathrm{L}, 0.99 \mathrm{mmol})$ in $\mathrm{CH}_{2} \mathrm{Cl}_{2}(2 \mathrm{~mL})$ were reacted for $20 \mathrm{~h}$ according to general procedure A to afford $13 \mathrm{aB}(221 \mathrm{mg}, 0.79 \mathrm{mmol}, 80 \%)$ as a colorless oil. $R_{f} 0.54$ (EtOAc/PE 1:2). ${ }^{1} \mathrm{H}$ NMR $\left(200 \mathrm{MHz}, \mathrm{CDCl}_{3}\right) \delta$ 7.50-7.15 (m, 5H, Ar-H), 6.00-5.70 (m, $\left.1 \mathrm{H}, \mathrm{CH}=\mathrm{CH}_{2}\right), 5.40-$ $5.10\left(\mathrm{~m}, 4 \mathrm{H}, \mathrm{CH}=\mathrm{CH}_{2}\right.$ and $\left.\mathrm{C}=\mathrm{CH}_{2}\right), 4.90(\mathrm{dd}, J=6.0,8.1 \mathrm{~Hz}, 1 \mathrm{H}, \mathrm{NHCH}), 4.54(\mathrm{dd}, J=1.0,5.6$ $\left.\mathrm{Hz}, 2 \mathrm{H}, \mathrm{OCH}_{2}\right), 4.20-3.90\left(\mathrm{~m}, 2 \mathrm{H}, \mathrm{CH}_{2} \mathrm{Cl}\right), 2.85-2.50\left(\mathrm{~m}, 2 \mathrm{H}, \mathrm{CH}_{2} \mathrm{C}=\mathrm{CH}_{2}\right) .{ }^{13} \mathrm{C}$ NMR $(100$ $\left.\mathrm{MHz}, \mathrm{CDCl}_{3}\right) \delta 155.5(\mathrm{OCON}), 141.8,141.2\left(\mathrm{Ar}-\mathrm{C}\right.$ and $\left.\mathrm{C}=\mathrm{CH}_{2}\right), 132.6\left(\mathrm{CH}=\mathrm{CH}_{2}\right), 128.6$, 127.5, 126.0 (Ar-C), 117.8, $117.6\left(\mathrm{C}=\mathrm{CH}_{2}\right.$ and $\left.\mathrm{CH}=\mathrm{CH}_{2}\right), 65.6\left(\mathrm{OCH}_{2}\right), 53.2(\mathrm{NHCH}), 47.7$ $\left(\mathrm{CH}_{2} \mathrm{Cl}\right), 40.3\left(\mathrm{CH}_{2} \mathrm{C}=\mathrm{CH}_{2}\right)$. IR $v, \mathrm{~cm}^{-1} 3331,3089,3035,2956,1703,1514,1439,1247,1032$, 994, 916. HRMS (FAB+) calculated for $\mathrm{C}_{15} \mathrm{H}_{19} \mathrm{NO}_{2} \mathrm{Cl}\left(\mathrm{M}^{+}+\mathrm{H}\right) 280.1104$, found 280.1115.

(1-Phenylbut-3-ynyl)carbamic acid allyl ester (13aC). Allyl carbamate 11 (100 mg, $0.99 \mathrm{mmol})$, benzaldehyde $(101 \mu \mathrm{L}, 0.99 \mathrm{mmol})$ allenyltributyltin $(294 \mu \mathrm{L}, 0.99 \mathrm{mmol})$ and 
$\mathrm{BF}_{3} \cdot \mathrm{OEt}_{2}(125 \mu \mathrm{L}, 0.99 \mathrm{mmol})$ in $\mathrm{CH}_{2} \mathrm{Cl}_{2}(2 \mathrm{~mL})$ were reacted for $20 \mathrm{~h}$ according to general procedure A to afford 13aC $(23 \mathrm{mg}, 0.01 \mathrm{mmol}, 10 \%)$ as a colorless oil. $R_{f} 0.54$ (EtOAc/PE 1:2). ${ }^{1} \mathrm{H}$ NMR $\left(200 \mathrm{MHz}, \mathrm{CDCl}_{3}\right) \delta$ 7.60-7.10 (m, 5H, Ar-H), 6.00-5.70 (m, $\left.1 \mathrm{H}, \mathrm{CH}=\mathrm{CH}_{2}\right), 5.05-$ $4.45\left(\mathrm{~m}, 2 \mathrm{H}, \mathrm{CH}=\mathrm{CH}_{2}\right), 4.90(\mathrm{t}, J=6.4 \mathrm{~Hz}, 1 \mathrm{H}, \mathrm{NHCH}), 4.55\left(\mathrm{td}, J=1.3,5.5 \mathrm{~Hz}, 2 \mathrm{H}, \mathrm{OCH}_{2}\right)$, $2.65\left(\mathrm{dd}, J=2.6,6.3 \mathrm{~Hz}, 2 \mathrm{H}, \mathrm{CH}_{2} \mathrm{C} \equiv \mathrm{CH}\right), 2.10(\mathrm{t}, J=2.6 \mathrm{~Hz}, 1 \mathrm{H}, \mathrm{C} \equiv \mathrm{CH}) .{ }^{13} \mathrm{C} \mathrm{NMR}(50 \mathrm{MHz}$, $\left.\mathrm{CDCl}_{3}\right) \delta 154.0(\mathrm{OCON}), 142.2(\mathrm{Ar}-\mathrm{C}), 132.5\left(\mathrm{CH}=\mathrm{CH}_{2}\right), 130.5,128.2,127.7,125.5$ (Ar-C), $117.4\left(\mathrm{CH}=\mathrm{CH}_{2}\right), 80.4(\mathrm{C} \equiv \mathrm{CH}), 72.1(\mathrm{C} \equiv \mathrm{CH}), 65.4\left(\mathrm{OCH}_{2}\right), 51.7(\mathrm{NHCH}), 29.2\left(\mathrm{CH}_{2} \mathrm{C} \equiv \mathrm{CH}\right) . \mathrm{IR} v, \mathrm{~cm}^{-1}$ 3294, 3033, 2924, 2854, 1709, 1608, 1497, 1453, 1252, 1049.

(1-Cyanobenzyl)carbamic acid allyl ester (13aD). Allyl carbamate 11 (100 mg, $0.99 \mathrm{mmol})$, benzaldehyde $(101 \mu \mathrm{L}, 0.99 \mathrm{mmol})$ trimethylsilyl cyanide $(132 \mu \mathrm{L}, 0.99 \mathrm{mmol})$ and $\mathrm{BF}_{3} \cdot \mathrm{OEt}_{2}$ $(125 \mu \mathrm{L}, 0.99 \mathrm{mmol})$ in $\mathrm{CH}_{2} \mathrm{Cl}_{2}(2 \mathrm{~mL})$ were reacted for $20 \mathrm{~h}$ according to general procedure A to afford 13aD (11 mg, $0.05 \mathrm{mmol}, 5 \%)$ as a colorless oil. $R_{f} 0.61$ (EtOAc/PE 1:2). ${ }^{1} \mathrm{H}$ NMR $\left(200 \mathrm{MHz}, \mathrm{CDCl}_{3}\right) \delta$ 7.60-7.30 (m, 5H, Ar-H), 6.00-5.70 (m, 1H, CH=CH$), 5.40-5.10(\mathrm{~m}, 2 \mathrm{H}$, $\left.\mathrm{CH}=\mathrm{CH}_{2}\right), 4.85-4.76(\mathrm{~m}, 1 \mathrm{H}, \mathrm{NHCH}), 4.66\left(\mathrm{~d}, \mathrm{~J}=6.0 \mathrm{~Hz}, 2 \mathrm{H}, \mathrm{OCH}_{2}\right)$.

[1-(2-Oxocyclohexyl)benzyl]carbamic acid allyl ester (13aE). Allyl carbamate 11 (100 mg, $0.99 \mathrm{mmol})$, benzaldehyde $(101 \mu \mathrm{L}, 0.99 \mathrm{mmol})$ 1-cyclohexenyloxytrimethylsilane $(193 \mu \mathrm{L}$, $0.99 \mathrm{mmol})$ and $\mathrm{BF}_{3} \cdot \mathrm{OEt}_{2}(125 \mu \mathrm{L}, 0.99 \mathrm{mmol})$ in $\mathrm{CH}_{2} \mathrm{Cl}_{2}(2 \mathrm{~mL})$ were reacted for $20 \mathrm{~h}$ according to general procedure A to afford 13aE (26 mg, $0.09 \mathrm{mmol}, 10 \%)$ as a colorless oil. $R_{f}$ 0.57 (EtOAc/PE 1:2). ${ }^{1} \mathrm{H}$ NMR (200 MHz, $\left.\mathrm{CDCl}_{3}\right) \delta$ 7.50-7.00 (m, 5H, Ar-H), 6.10-5.80 (m, 1H, $\left.\mathrm{CH}=\mathrm{CH}_{2}\right), 5.35-5.10\left(\mathrm{~m}, 2 \mathrm{H}, \mathrm{CH}=\mathrm{CH}_{2}\right), 5.10-4.90(\mathrm{~m}, 1 \mathrm{H}, \mathrm{NHCH}), 4.48(\mathrm{~d}, J=5.4 \mathrm{~Hz}, 2 \mathrm{H}$, $\left.\mathrm{OCH}_{2}\right), 3.07(\mathrm{dd}, J=4.7,12.5 \mathrm{~Hz}, 1 \mathrm{H}, \mathrm{COCH}), 2.90-2.75\left(\mathrm{~m}, 2 \mathrm{H}, \mathrm{CH}_{2}\right), 2.56(\mathrm{t}, J=6.7 \mathrm{~Hz}$, $\left.\mathrm{CH}_{2}\right), 2.40-2.15\left(\mathrm{~m}, 4 \mathrm{H}, 2 \times \mathrm{CH}_{2}\right) .{ }^{13} \mathrm{C} \mathrm{NMR}\left(100 \mathrm{MHz}, \mathrm{CDCl}_{3}\right) \delta 201.7\left(\mathrm{CH}_{2} \mathrm{CO}\right), 154.5$ (OCON), 140.4 (Ar-C), $135.4\left(\mathrm{CH}=\mathrm{CH}_{2}\right), 130.2,128.1,126.2(\mathrm{Ar}-\mathrm{C}), 116.8\left(\mathrm{CH}=\mathrm{CH}_{2}\right), 63.6$ $\left(\mathrm{OCH}_{2}\right), 56.6(\mathrm{COCH}), 49.4(\mathrm{NHCH}), 38.4,33.2,26.4,22.3\left(4 \times \mathrm{CH}_{2}\right) . \mathrm{IR} v, \mathrm{~cm}^{-1} 3364,3029$, 2936, 2861, 1752, 1709, 1650, 1506, 1448, 1378, 1242, 1088, 922.

[1-(2-Oxo-2-phenylethyl)benzyl]carbamic acid allyl ester (13aF). Allyl carbamate 11 (100 mg, $0.99 \mathrm{mmol})$, benzaldehyde (101 $\mu \mathrm{L}, 0.99 \mathrm{mmol})$ 1-phenyl-1-(trimethylsilyloxy)ethylene $(203 \mu \mathrm{L}, 0.99 \mathrm{mmol})$ and $\mathrm{BF}_{3} \cdot \mathrm{OEt}_{2}(125 \mu \mathrm{L}, 0.99 \mathrm{mmol})$ in $\mathrm{CH}_{2} \mathrm{Cl}_{2}(2 \mathrm{~mL})$ were reacted for $20 \mathrm{~h}$ according to general procedure A to afford $13 \mathrm{aF}(18 \mathrm{mg}, 0.06 \mathrm{mmol}, 6 \%)$ as a colorless oil. $R_{f}$ 0.45 (EtOAc/PE 1:2). ${ }^{1} \mathrm{H} \mathrm{NMR}\left(200 \mathrm{MHz}, \mathrm{CDCl}_{3}\right) \delta$ 7.60-7.00 (m, 10H, Ar-H), 6.05-5.70 (m, $\left.1 \mathrm{H}, \mathrm{CH}=\mathrm{CH}_{2}\right), 5.40-5.10\left(\mathrm{~m}, 3 \mathrm{H}, \mathrm{NHCH}\right.$ and $\left.\mathrm{CH}=\mathrm{CH}_{2}\right), 4.55\left(\mathrm{dd}, J=1.3,5.6 \mathrm{~Hz}, 2 \mathrm{H}, \mathrm{OCH}_{2}\right)$, $3.70\left(\mathrm{dd}, J=5.2,16.9 \mathrm{~Hz}, 1 \mathrm{H}, \mathrm{COCH}_{2}\right), 3.46\left(\mathrm{dd}, J=6.0,16.8 \mathrm{~Hz}, 1 \mathrm{H}, \mathrm{COCH}_{2}\right) .{ }^{13} \mathrm{C} \mathrm{NMR}$ 155.3 (OCON), 141.1, 136.3, 134.3, 132.5, 128.9, 128.5, 127.2, 127.0, 121.7 (Ar-C and $\left.\mathrm{CH}=\mathrm{CH}_{2}\right), 117.5\left(\mathrm{CH}=\mathrm{CH}_{2}\right), 65.5\left(\mathrm{OCH}_{2}\right), 51.4(\mathrm{NHCH}), 29.6\left(\mathrm{COCH}_{2}\right) . \mathrm{IR} \mathrm{v}, \mathrm{cm}^{-1} 3337,3084$, 2926, 1740, 1694, 1539, 1450, 1253, 1045, 931. HRMS (FAB+) calculated for $\mathrm{C}_{19} \mathrm{H}_{20} \mathrm{NO}_{3}\left(\mathrm{M}^{+}+\right.$ H) 310.1443 , found 310.1447 .

(1-Phenylbut-3-enyl)carbamic acid benzyl ester (15aA). ${ }^{8}$ Benzyl carbamate $(1.20 \mathrm{~g}$, $7.94 \mathrm{mmol})$, benzaldehyde $(807 \mu \mathrm{L}, 7.94 \mathrm{mmol})$, allyltrimethylsilane $(1.27 \mu \mathrm{L}, 7.94 \mathrm{mmol})$ and $\mathrm{BF}_{3} \cdot \mathrm{OEt}_{2}(976 \mu \mathrm{L}, 7.94 \mathrm{mmol})$ in $\mathrm{CH}_{2} \mathrm{Cl}_{2}(10 \mathrm{~mL})$ were reacted for $3 \mathrm{~h}$ at $\mathrm{rt}$ according to general procedure A to afford $15 \mathrm{aA}(2.05 \mathrm{~g}, 7.30 \mathrm{mmol}, 92 \%)$ as a white solid. Mp $56{ }^{\circ} \mathrm{C} . R_{f} 0.40$ 
(EtOAc/PE 1:2). ${ }^{1} \mathrm{H}$ NMR (400 MHz, $\left.\mathrm{CDCl}_{3}\right) \delta$ 7.38-7.25 (m, 10H, Ar-H), 5.76-5.65 (m, 1H, $\left.\mathrm{CH}=\mathrm{CH}_{2}\right), 5.28($ br s, $1 \mathrm{H}, \mathrm{NH}), 5.15-5.07\left(\mathrm{~m}, 4 \mathrm{H}, \mathrm{OCH}_{2}\right.$ and $\left.\mathrm{CH}=\mathrm{CH}_{2}\right), 4.87-4.80(\mathrm{~m}, 1 \mathrm{H}$, $\mathrm{NHCH}$ ), 2.56 (br s, $\left.2 \mathrm{H}, \mathrm{CH}_{2} \mathrm{CH}=\mathrm{CH}_{2}\right) .{ }^{13} \mathrm{C} \mathrm{NMR}\left(100 \mathrm{MHz}, \mathrm{CDCl}_{3}\right.$ ) $\delta 155.6$ (OCON), 136.3, 133.6, 129.9, 128.5, 128.3, 128.1, 127.1, 126.2, 126.0 (Ar-C and $\left.\mathrm{CH}=\mathrm{CH}_{2}\right), 118.2\left(\mathrm{CH}=\mathrm{CH}_{2}\right)$, $66.7\left(\mathrm{OCH}_{2}\right), 54.4(\mathrm{NHCH}), 40.9\left(\mathrm{CH}_{2} \mathrm{CH}=\mathrm{CH}_{2}\right)$. IR $v, \mathrm{~cm}^{-1} 3319,3064,1709,1531,1454$, 1340, 1252, 1028, 917.

6-Benzyloxycarbonylamino-6-phenylhex-3-enoic acid methyl ester (15aG). Benzyl carbamate (100 mg, $0.66 \mathrm{mmol})$, benzaldehyde $(67 \mu \mathrm{L}, 0.66 \mathrm{mmol})$, methyl 3-(trimethylsilyl)-4pentenoate $(137 \mu \mathrm{L}, 0.66 \mathrm{mmol})$ and $\mathrm{BF}_{3} \cdot \mathrm{OEt}_{2}(81 \mu \mathrm{L}, 0.66 \mathrm{mmol})$ in $\mathrm{CH}_{2} \mathrm{Cl}_{2}(2 \mathrm{~mL})$ were reacted for $4 \mathrm{~h}$ at $\mathrm{rt}$ according to general procedure A to afford 15aG (165 $\mathrm{mg}, 0.47 \mathrm{mmol}, 71 \%$ ) as a colorless oil. $R_{f} 0.35\left(\mathrm{EtOAc} / \mathrm{PE} \mathrm{1:2).}{ }^{1} \mathrm{H}\right.$ NMR $\left(400 \mathrm{MHz}, \mathrm{CDCl}_{3}\right) \delta$ 7.90-7.24 (m, 10H, Ar-H), 5.67-5.59 (m, $\left.1 \mathrm{H}, \mathrm{MeO}_{2} \mathrm{CCH}_{2} \mathrm{CH}=\mathrm{CH}\right), 5.46-5.41\left(\mathrm{~m}, 1 \mathrm{H}, \mathrm{MeO}_{2} \mathrm{CCH}_{2} \mathrm{CH}=\mathrm{CH}\right), 5.21$ (br s, $1 \mathrm{H}, \mathrm{NH}), 5.12-5.03\left(\mathrm{~m}, 2 \mathrm{H}, \mathrm{ArCH}_{2}\right), 4.81$ (br s, $\left.1 \mathrm{H}, \mathrm{NHCH}\right), 3.65$ (s, 3H, $\left.\mathrm{CO}_{2} \mathrm{Me}\right), 3.00$ (d, $J$ $\left.=6.8 \mathrm{~Hz}, 2 \mathrm{H}, \mathrm{CH}_{2} \mathrm{CO}_{2} \mathrm{Me}\right), 2.55-2.53\left(\mathrm{~m}, 2 \mathrm{H}, \mathrm{CHCH}_{2}\right)$. Only one double bond isomer was found, the configuration of the double bond was established by a ${ }^{1} \mathrm{H}$ NMR homo decoupling experiment. Upon irradiation at $3.00 \mathrm{ppm} \mathrm{a}{ }^{3} J$ of $15.5 \mathrm{~Hz}$ between the two double bond signals was observed, which can be assigned to the $(E)$-isomer. ${ }^{13} \mathrm{C} \mathrm{NMR}\left(100 \mathrm{MHz}, \mathrm{CDCl}_{3}\right) \delta 171.9$ $\left(\mathrm{CO}_{2} \mathrm{Me}\right), 155.7(\mathrm{OCON}), 141.8,136.5,129.6,128.9,128.5,128.0,127.2,126.2,125.6,123.9$ $(\mathrm{Ar}-\mathrm{C}$ and $\mathrm{CH}=\mathrm{CH}), 66.6\left(\mathrm{ArCH}_{2}\right), 54.5\left(\mathrm{CO}_{2} \mathrm{Me}\right), 51.7(\mathrm{NHCH}), 37.6\left(\mathrm{CH}_{2} \mathrm{CO}_{2} \mathrm{Me}\right), 32.7$ $\left(\mathrm{CHCH}_{2}\right)$. IR $v, \mathrm{~cm}^{-1} 3329,3031,2950,1745,1702,1524,1330,1243,1026,970,843$. HRMS $(\mathrm{FAB}+)$ calculated for $\mathrm{C}_{21} \mathrm{H}_{24} \mathrm{NO}_{4}\left(\mathrm{M}^{+}+\mathrm{H}\right) 354.1705$, found 354.1716.

(2-Methylene-1-phenylbut-3-enyl)carbamic acid benzyl ester (15aJ). Benzyl carbamate (100 mg, $0.66 \mathrm{mmol}$ ), benzaldehyde $(67 \mu \mathrm{L}, 0.66 \mathrm{mmol})$, (allenylmethyl)trimethylsilane (158 $\mu \mathrm{L}$, $0.99 \mathrm{mmol})$ and $\mathrm{BF}_{3} \cdot \mathrm{OEt}_{2}(81 \mu \mathrm{L}, 0.66 \mathrm{mmol})$ in $\mathrm{CH}_{2} \mathrm{Cl}_{2}(2 \mathrm{~mL})$ were reacted for $4 \mathrm{~h}$ at $\mathrm{rt}$ according to general procedure A to afford $15 \mathrm{aJ}(120 \mathrm{mg}, 0.41 \mathrm{mmol}, 62 \%)$ as a colorless oil. $R_{f}$ 0.80 (EtOAc/PE 1:1). ${ }^{1} \mathrm{H}$ NMR $\left(400 \mathrm{MHz}, \mathrm{CDCl}_{3}\right) \delta$ 7.35-7.27 (s, 10H, Ar-H), 6.33 (dd, $J=$ 11.2, $17.8 \mathrm{~Hz}, 1 \mathrm{H}, \mathrm{CH}=\mathrm{CH}_{2}$ ), 5.66 (br d, $\left.J=7.8 \mathrm{~Hz}, 1 \mathrm{H}, \mathrm{NH}\right), 5.19-5.07$ (m, 7H, NHCH, $\mathrm{ArCH}_{2}, \mathrm{C}=\mathrm{CH}_{2}$ and $\left.\mathrm{CH}=\mathrm{CH}_{2}\right) .{ }^{13} \mathrm{C} \mathrm{NMR}\left(50 \mathrm{MHz}, \mathrm{CDCl}_{3}\right) \delta 155.2(\mathrm{OCON}), 145.6,139.9$, 136.2, 135.9, 128.4, 128.3, 127.9, $127.4,126.9$ (Ar-C, $C=\mathrm{CH}_{2}$ and $\mathrm{CH}=\mathrm{CH}_{2}$ ), 116.6, 115.5 $\left(\mathrm{C}=\mathrm{CH}_{2}\right.$ and $\left.\mathrm{CH}=\mathrm{CH}_{2}\right), 66.7\left(\mathrm{ArCH}_{2}\right), 55.9(\mathrm{NHCH}) . \mathrm{IR} v, \mathrm{~cm}^{-1} 3320,3089,1697,1497,1237$, 1026, 910. HRMS (FAB+) calculated for $\mathrm{C}_{19} \mathrm{H}_{20} \mathrm{NO}_{2}\left(\mathrm{M}^{+}+\mathrm{H}\right)$ 294.1494, found 294.1495.

(3-Oxo-1-phenylbutyl)carbamic acid benzyl ester (15aK). Benzyl carbamate (100 mg, $0.66 \mathrm{mmol})$, benzaldehyde $(67 \mu \mathrm{L}, 0.66 \mathrm{mmol})$, isopropenyl acetate $(73 \mu \mathrm{L}, 0.66 \mathrm{mmol})$ and $\mathrm{Sc}(\mathrm{OTf})_{3}(33 \mathrm{mg}, 0.07 \mathrm{mmol})$ in $\mathrm{CH}_{2} \mathrm{Cl}_{2}(2 \mathrm{~mL})$ were reacted for $18 \mathrm{~h}$ at $\mathrm{rt}$ according to general procedure A to afford 15aK (56 $\mathrm{mg}, 0.15 \mathrm{mmol}, 28 \%$ ) as a colorless oil. $R_{f} 0.35$ (EtOAc/PE 1:1). ${ }^{1} \mathrm{H}$ NMR (400 MHz, $\left.\mathrm{CDCl}_{3}\right) \delta$ 7.37-7.23 (m, 5H, Ar-H), 5.80 (br d, J=7.3 Hz, 1H, NH), 5.18-5.05 (m, 3H, $\mathrm{ArCH}_{2}$ and $\left.\mathrm{NHCH}\right), 3.08-3.04\left(\mathrm{~m}, 2 \mathrm{H}, \mathrm{MeCOCH}_{2}\right), 2.91(\mathrm{dd}, J=5.3,16.3$ $\left.\mathrm{Hz}, 1 \mathrm{H}, \mathrm{MeCOCH}_{2}\right), 2.07$ (s, 3H, MeCO). ${ }^{13} \mathrm{C} \mathrm{NMR} \mathrm{(50} \mathrm{MHz,} \mathrm{CDCl}_{3}$ ) $\delta 206.4$ (MeCO), 155.4 (OCON), 141.0, 136.2, 128.5, 128.3, 128.0, 127.9, 127.3, 126.0 (Ar-C), $66.5\left(\mathrm{ArCH}_{2}\right), 51.3$ 
(NHCH), $48.7\left(\mathrm{MeCOCH}_{2}\right), 30.4$ (MeCO). IR v, $\mathrm{cm}^{-1}$ 3302, 3026, 2932, 1718, 1702, 1524, 1340, 1251. HRMS (EI+) calculated for $\mathrm{C}_{18} \mathrm{H}_{19} \mathrm{NO}_{3}\left(\mathrm{M}^{+}\right)$297.1365, found 297.1362.

(1-Phenylbut-3-enyl)carbamic acid 2-benzylsulfonylethyl ester (17aA). Carbamate 8 (500 mg, $1.96 \mathrm{mmol})$, benzaldehyde $(200 \mu \mathrm{L}, 1.96 \mathrm{mmol})$, allyltrimethylsilane $(312 \mu \mathrm{L}$, $1.96 \mathrm{mmol})$ and $\mathrm{BF}_{3} \cdot \mathrm{OEt}_{2}(241 \mu \mathrm{L}, 1.96 \mathrm{mmol})$ in $\mathrm{CH}_{2} \mathrm{Cl}_{2}(10 \mathrm{~mL})$ were reacted for $4 \mathrm{~h}$ at $\mathrm{rt}$ according to general procedure A to afford 17aA $(672 \mathrm{mg}, 1.75 \mathrm{mmol}, 89 \%)$ as a white solid. $R_{f}$ 0.38 (EtOAc/PE 1:1). ${ }^{1} \mathrm{H}$ NMR (400 MHz, $\left.\mathrm{CDCl}_{3}\right) \delta$ 7.41-7.27 (m, 10H, Ar-H), 5.71-5.63 (m, $\left.1 \mathrm{H}, \mathrm{CH}=\mathrm{CH}_{2}\right), 5.19-5.08\left(\mathrm{~m}, 3 \mathrm{H}, \mathrm{NH}\right.$ and $\left.\mathrm{CH}=\mathrm{CH}_{2}\right), 4.78(\mathrm{~d}, J=6.7 \mathrm{~Hz}, 1 \mathrm{H}, \mathrm{NHCH}), 4.46(\mathrm{t}, J$ $\left.=6.0 \mathrm{~Hz}, 2 \mathrm{H}, \mathrm{OCH}_{2}\right), 4.24\left(\mathrm{~s}, 2 \mathrm{H}, \mathrm{ArCH}_{2}\right), 3.15\left(\mathrm{br} \mathrm{s}, 2 \mathrm{H}, \mathrm{SO}_{2} \mathrm{CH}_{2}\right), 2.57-2.53(\mathrm{~m}, 2 \mathrm{H}$, $\left.\mathrm{CH}_{2} \mathrm{CH}=\mathrm{CH}_{2}\right) .{ }^{13} \mathrm{C} \mathrm{NMR}\left(100 \mathrm{MHz}, \mathrm{CDCl}_{3}\right) \delta 154.5$ (OCON), 133.5, 130.6, 129.0, 128.9, 128.6, 127.4, 126.1 (Ar-C and $\left.\mathrm{CH}=\mathrm{CH}_{2}\right), 118.5\left(\mathrm{CH}=\mathrm{CH}_{2}\right), 60.6,57.8\left(\mathrm{OCH}_{2}\right.$ and $\left.\mathrm{ArCH}{ }_{2}\right), 54.6$ $(\mathrm{NHCH}), 50.7\left(\mathrm{SO}_{2} \mathrm{CH}_{2}\right), 40.8\left(\mathrm{CH}_{2} \mathrm{CH}=\mathrm{CH}_{2}\right) . \mathrm{IR} v, \mathrm{~cm}^{-1} 3345,3033,2956,1714,1537,1305$, 1253, 1118, 920.

(1-Benzylbut-3-enyl)carbamic acid 2-benzylsulfonylethyl ester (17fA). Carbamate 8 (500 mg, $2.06 \mathrm{mmol})$, phenylacetaldehyde diethyl acetal $(340 \mu \mathrm{L}, 2.06 \mathrm{mmol})$, allyltrimethylsilane $(328 \mu \mathrm{L}, 2.06 \mathrm{mmol})$ and $\mathrm{BF}_{3} \cdot \mathrm{OEt}_{2}(253 \mu \mathrm{L}, 2.06 \mathrm{mmol})$ in $\mathrm{MeCN}(10 \mathrm{~mL})$ were reacted for $6 \mathrm{~h}$ at $50{ }^{\circ} \mathrm{C}$ according to general procedure A to afford 17fA $(652 \mathrm{mg}, 1.68 \mathrm{mmol}, 82 \%)$ as a white solid. $R_{f} 0.47$ (EtOAc/PE 1:1). ${ }^{1} \mathrm{H}$ NMR $\left(400 \mathrm{MHz}, \mathrm{CDCl}_{3}\right) \delta$ 7.39-7.16 (m, 10H, Ar-H), 5.825.74 (m, 1H, $\mathrm{CH}=\mathrm{CH}_{2}$ ), 5.12-5.08 (m, 2H, $\left.\mathrm{CH}=\mathrm{CH}_{2}\right), 4.67$ (br d, $\left.J=7.7 \mathrm{~Hz}, 1 \mathrm{H}, \mathrm{NH}\right), 4.43$ (br s, 2H, $\left.\mathrm{OCH}_{2}\right), 4.20\left(\mathrm{~s}, 2 \mathrm{H}, \mathrm{ArCH}_{2} \mathrm{SO}_{2}\right), 4.00-3.95(\mathrm{~m}, 1 \mathrm{H}, \mathrm{NHCH}), 3.13$ (t, $\left.J=5.6 \mathrm{~Hz}, 2 \mathrm{H}, \mathrm{SO}_{2} \mathrm{CH}_{2}\right), 2.80(\mathrm{~d}, J=$ $\left.6.6 \mathrm{~Hz}, 2 \mathrm{H}, \mathrm{ArCH}_{2} \mathrm{CH}\right), 2.34-2.13$ (m, $2 \mathrm{H}, \mathrm{CH}_{2} \mathrm{CH}=\mathrm{CH}_{2}$ ). IR $v, \mathrm{~cm}^{-1} 3348,3029,2978,1715,1530,1284$, $1245,1123$.

(1-Phenylbut-3-enyl)carbamic acid 2-benzylsulfanylethyl ester (18aA). Carbamate 9 (500 mg, $2.37 \mathrm{mmol})$, benzaldehyde $(241 \mu \mathrm{L}, 2.37 \mathrm{mmol})$, allyltrimethylsilane (378 $\mu \mathrm{L}$, $2.37 \mathrm{mmol})$ and $\mathrm{BF}_{3} \cdot \mathrm{OEt}_{2}(291 \mu \mathrm{L}, 2.37 \mathrm{mmol})$ in $\mathrm{MeCN}(15 \mathrm{~mL})$ were reacted for $4 \mathrm{~h}$ at $\mathrm{rt}$ according to general procedure A to afford 18aA (526 mg, $1.54 \mathrm{mmol}, 65 \%)$ as a white solid. $R_{f}$ 0.29 (EtOAc/PE 1:2). ${ }^{1} \mathrm{H}$ NMR (400 MHz, $\left.\mathrm{CDCl}_{3}\right) \delta$ 7.39-7.22 (m, 10H, Ar-H), 5.74-5.64 (m, $\left.1 \mathrm{H}, \mathrm{CH}=\mathrm{CH}_{2}\right), 5.15-5.05\left(\mathrm{~m}, 3 \mathrm{H}, \mathrm{NH}\right.$ and $\left.\mathrm{CH}=\mathrm{CH}_{2}\right), 4.79(\mathrm{~d}, J=5.6 \mathrm{~Hz}, 1 \mathrm{H}, \mathrm{NHCH}), 4.16(\mathrm{t}, J$ $\left.=6.7 \mathrm{~Hz}, 2 \mathrm{H}, \mathrm{OCH}_{2}\right), 3.73\left(\mathrm{~d}, J=2.8 \mathrm{~Hz}, 2 \mathrm{H}, \mathrm{ArCH}_{2}\right), 2.67-2.53\left(\mathrm{~m}, 4 \mathrm{H}, \mathrm{SCH}_{2}\right.$ and $\left.\mathrm{CH}_{2} \mathrm{CH}=\mathrm{CH}_{2}\right) .{ }^{13} \mathrm{C} \mathrm{NMR}\left(100 \mathrm{MHz}, \mathrm{CDCl}_{3}\right) \delta 155.3$ (OCON), 141.8, 133.6, 128.8, 128.5, 128.4, 128.0, 127.2, 127.0, 126.1 (Ar-C and $\left.\mathrm{CH}=\mathrm{CH}_{2}\right), 118.3\left(\mathrm{CH}=\mathrm{CH}_{2}\right), 63.8\left(\mathrm{OCH}_{2}\right), 54.3(\mathrm{NHCH})$, 43.1, 36.2, $30.0\left(\mathrm{ArCH}_{2}, \mathrm{SCH}_{2}\right.$ and $\left.\mathrm{CH}_{2} \mathrm{CH}=\mathrm{CH}_{2}\right)$. IR $v, \mathrm{~cm}^{-1} 3326,3029,2919,1707,1524$, $1453,1250,1010$.

(1-Hexylbut-3-enyl)carbamic acid 2-benzylsulfanylethyl ester (18gA). Carbamate 9 (50 mg, $0.24 \mathrm{mmol}$ ), $n$-heptanal diethyl acetal (49 $\mathrm{mg}, 0.26 \mathrm{mmol}$ ), allyltrimethylsilane (38 $\mu \mathrm{L}$, $0.24 \mathrm{mmol})$ and $\mathrm{BF}_{3} \cdot \mathrm{OEt}_{2}(29 \mu \mathrm{L}, 0.24 \mathrm{mmol})$ in $\mathrm{CH}_{2} \mathrm{Cl}_{2}(1.5 \mathrm{~mL})$ were reacted for $18 \mathrm{~h}$ at $\mathrm{rt}$ according to general procedure A to afford 18gA (54 mg, $0.15 \mathrm{mmol}, 66 \%)$ as a colorless oil. $R_{f}$ 0.49 (EtOAc/PE 1:3). ${ }^{1} \mathrm{H}$ NMR (400 MHz, $\left.\mathrm{CDCl}_{3}\right) \delta$ 7.35-7.22 (m, 5H, Ar-H), 5.79-5.73 (m, 1H, $\left.\mathrm{CH}=\mathrm{CH}_{2}\right), 5.09-5.05\left(\mathrm{~m}, 2 \mathrm{H}, \mathrm{CH}=\mathrm{CH}_{2}\right), 4.45$ (br d, $\left.J=8.4 \mathrm{~Hz}, 1 \mathrm{H}, \mathrm{NH}\right), 4.16(\mathrm{~d}, J=6.6 \mathrm{~Hz}$, 
$\left.2 \mathrm{H}, \mathrm{OCH}_{2}\right), 3.75\left(\mathrm{~s}, 2 \mathrm{H}, \mathrm{ArCH}_{2}\right), 3.69-3.66(\mathrm{~m}, 1 \mathrm{H}, \mathrm{NHCH}), 2.63\left(\mathrm{~d}, J=6.7 \mathrm{~Hz}, 2 \mathrm{H}, \mathrm{SCH}_{2}\right)$, 2.28-2.16 (m, $\left.2 \mathrm{H}, \mathrm{CH}_{2} \mathrm{CH}=\mathrm{CH}_{2}\right), 1.51-1.26(\mathrm{~m}, 10 \mathrm{H}, n-\mathrm{Hex}), 0.87$ (t, $\left.J=6.5 \mathrm{~Hz}, 3 \mathrm{H}, n-\mathrm{Hex}\right)$.

Preparation of bis-carbamate 21 and homoallylic carbamate 15hA. Benzyl carbamate (100 mg, $0.66 \mathrm{mmol}$ ) was dissolved in $\mathrm{CH}_{2} \mathrm{Cl}_{2}(2 \mathrm{~mL})$, phthalimidoacetaldehyde diethyl acetal (174 mg, $0.66 \mathrm{mmol}$ ), allyltrimethylsilane $(106 \mu \mathrm{L}, 0.66 \mathrm{mmol})$ and $\mathrm{BF}_{3} \cdot \mathrm{OEt}_{2}(81 \mu \mathrm{l}$, $0.66 \mathrm{mmol}$ ) were subsequently added, after $5 \mathrm{~min}$ a white precipitate was formed and the resulting suspension was stirred for $18 \mathrm{~h}$ at $\mathrm{rt}$. Then, saturated aqueous $\mathrm{NaHCO}_{3}(3 \mathrm{~mL})$ was added and the layers were separated. The aqueous layer was extracted with $\mathrm{CH}_{2} \mathrm{Cl}_{2}(2 \times 2 \mathrm{~mL})$, the combined organic layers were washed with aqueous saturated $\mathrm{NaCl}(5 \mathrm{~mL})$, dried $\left(\mathrm{MgSO}_{4}\right)$ and concentrated in vacuo. The resulting solid material was triturated with EtOAc/PE (1:1, $2 \mathrm{~mL})$ and filtrated. The white, solid residue was washed with EtOAc/PE (1:1, $2 \times 2 \mathrm{~mL})$, the combined filtrates were concentrated in vacuo and purified using column chromatography resulting in $25 \mathrm{mg}(0.17 \mathrm{mmol}, 25 \%)$ of benzyl carbamate and $57 \mathrm{mg}(0.16 \mathrm{mmol}, 24 \%)$ of homoallylic carbamate 15hA. The solid residue was dried in vacuo to afford $78 \mathrm{mg}(0.17 \mathrm{mmol}, 25 \%)$ of biscarbamate $\mathbf{2 1}$ as a white solid.

[1-Benzyloxycarbonylamino-2-(1,3-dioxo-1,3-dihydroisoindol-2-yl)ethyl]carbamic acid benzyl ester (21). $R_{f} 0.05$ (EtOAc/PE 1:1). ${ }^{1} \mathrm{H} \mathrm{NMR}\left(400 \mathrm{MHz}, \mathrm{CDCl}_{3}\right) \delta$ 7.85-7.82 (m, 2H, Ar-H), 7.73-7.71 (m, 2H, Ar-H), 7.31-7.26 (m, 10H, Ar-H), 5.87 (br d, J=6.5 Hz, 2H, $2 \times \mathrm{NH}), 5.29$ (br s, $1 \mathrm{H}, \mathrm{NHCHNH}), 5.07\left(\mathrm{~s}, 4 \mathrm{H}, 2 \times \mathrm{ArCH}_{2}\right), 4.16-4.11\left(\mathrm{~m}, 2 \mathrm{H}, \mathrm{NCH}_{2}\right) .{ }^{13} \mathrm{C} \mathrm{NMR}(50 \mathrm{MHz}$, $\left.\mathrm{CDCl}_{3}\right) \delta 167.9(\mathrm{CONCO}), 155.1(2 \times \mathrm{OCON}), 135.5,134.0,131.5,128.2,127.9,127.8,123.4$ $(\mathrm{Ar}-\mathrm{C}), 66.8\left(2 \times \mathrm{ArCH}_{2}\right), 59.0(\mathrm{NHCHNH}), 40.0\left(\mathrm{NCH}_{2}\right) . \mathrm{IR} v, \mathrm{~cm}^{-1} 3306,1709,1509,1398$, 1236, 1031. HRMS (FAB+) calculated for $\mathrm{C}_{26} \mathrm{H}_{24} \mathrm{~N}_{3} \mathrm{O}_{6}\left(\mathrm{M}^{+}+\mathrm{H}\right)$ 474.1665, found 474.1649. Bis-carbamate 21 (70 mg, $0.15 \mathrm{mmol}$ ) was dissolved in $\mathrm{MeCN}$ (2 mL), allyltrimethylsilane $(24 \mu \mathrm{L}, 0.15 \mathrm{mmol})$ and $\mathrm{BF}_{3} \cdot \mathrm{OEt}_{2}(18 \mu \mathrm{L}, 0.15 \mathrm{mmol})$ were added and the reaction mixture was stirred for $18 \mathrm{~h}$ at $\mathrm{rt}$. Then, saturated aqueous $\mathrm{NaHCO}_{3}(3 \mathrm{~mL})$ was added and the layers were separated. The aqueous layer was extracted with $\mathrm{CH}_{2} \mathrm{Cl}_{2}(2 \times 2 \mathrm{~mL})$, the combined organic layers were washed with aqueous saturated $\mathrm{NaCl}(5 \mathrm{~mL})$, dried $\left(\mathrm{MgSO}_{4}\right)$ and concentrated in vacuo. The crude product was purified using column chromatography (EtOAc/PE 1:1) to afford a second portion of $\mathbf{1 5 h A}$ (20 $\mathrm{mg}, 0.06 \mathrm{mmol}, 37 \%$ ) as a colorless oil.

[1-(1,3-Dioxo-1,3-dihydroisoindol-2-ylmethyl)but-3-enyl]carbamic acid benzyl ester (15hA). $R_{f} 0.45$ (EtOAc/PE 1:1). ${ }^{1} \mathrm{H}$ NMR $\left(400 \mathrm{MHz}, \mathrm{CDCl}_{3}\right) \delta$ 7.83-7.81 (m, 2H, Ar-H), 7.72-7.69 (m, $2 \mathrm{H}, \mathrm{Ar}-\mathrm{H}), 7.30-7.22(\mathrm{~m}, 5 \mathrm{H}, \mathrm{Ar}-\mathrm{H}), 5.89-5.78\left(\mathrm{~m} \mathrm{1H}, \mathrm{CH}=\mathrm{CH}_{2}\right), 5.16-4.91\left(\mathrm{~m}, 5 \mathrm{H}, \mathrm{CH}=\mathrm{CH}_{2}\right.$, $\mathrm{NH}$ and $\left.\mathrm{ArCH}_{2}\right), 4.12-4.10(\mathrm{~m}, 1 \mathrm{H}, \mathrm{NHCH}), 3.81-3.70\left(\mathrm{~m}, 2 \mathrm{H}, \mathrm{NCH}_{2}\right), 2.40-2.27(\mathrm{~m}, 2 \mathrm{H}$, $\left.\mathrm{CH}_{2} \mathrm{CH}=\mathrm{CH}_{2}\right) .{ }^{13} \mathrm{C}$ NMR $\left(100 \mathrm{MHz}, \mathrm{CDCl}_{3}\right) \delta 168.4$ (CONCO), 155.6 (OCON), 136.4, 133.9, 133.0, 131.8, 128.2, 127.8, 127.7, $123.3\left(\mathrm{Ar}-\mathrm{C}\right.$ and $\left.\mathrm{CH}=\mathrm{CH}_{2}\right), 118.6\left(\mathrm{CH}=\mathrm{CH}_{2}\right), 66.4\left(\mathrm{ArCH}_{2}\right)$, $50.0(\mathrm{NHCH}), 41.2\left(\mathrm{NCH}_{2}\right), 37.2\left(\mathrm{CH}_{2} \mathrm{CH}=\mathrm{CH}_{2}\right)$. IR $v, \mathrm{~cm}^{-1} 3360,3068,2912,1773,1723$, 1526, 1397, 1253, 1009. HRMS (FAB+) calculated for $\mathrm{C}_{21} \mathrm{H}_{21} \mathrm{~N}_{2} \mathrm{O}_{4}\left(\mathrm{M}^{+}+\mathrm{H}\right) 365.1501$, found 365.1497. 


\section{General procedure B for the $\boldsymbol{N}$-acyliminium ion reaction with carbamate 11}

Carbamate $\mathbf{1 1}^{8}$ and the nucleophile were dissolved in $\mathrm{CH}_{2} \mathrm{Cl}_{2} \cdot \mathrm{BF}_{3} \cdot \mathrm{OEt}_{2}$ was added and the reaction mixture was stirred for the indicated time at $\mathrm{rt}$. Then, aqueous $\mathrm{Na}_{2} \mathrm{CO}_{3}(10 \%)$ was added and the layers were separated. The aqueous layer was extracted with $\mathrm{CH}_{2} \mathrm{Cl}_{2}(2 \times)$, the combined organic layers were washed with aqueous saturated $\mathrm{NaCl}$, dried $\left(\mathrm{MgSO}_{4}\right)$ and concentrated in vacuo. The crude product was purified using column chromatography (EtOAc/PE).

(1-Phenylbut-3-enyl)carbamic acid benzyl ester (15aA) from 11. Carbamate 11 (100 mg, $0.28 \mathrm{mmol})$, allyltrimethylsilane $(89 \mu \mathrm{L}, 0.56 \mathrm{mmol})$ and $\mathrm{BF}_{3} \cdot \mathrm{OEt}_{2}(71 \mu \mathrm{L}, 0.56 \mathrm{mmol})$ in $\mathrm{CH}_{2} \mathrm{Cl}_{2}(2 \mathrm{~mL})$, were reacted for $18 \mathrm{~h}$ according to general procedure $\mathrm{B}$ to afford $15 \mathrm{aA}(62 \mathrm{mg}, 0.22 \mathrm{mmol}, 80 \%)$ as a colorless oil which was identical to the compound obtained from benzyl carbamate (14).

(2-Methylene-1-phenylbut-3-enyl)carbamic acid benzyl ester (15aJ) from 11. Carbamate 11 (100 mg, $0.28 \mathrm{mmol})$, (allenylmethyl)trimethylsilane $(45 \mu \mathrm{L}, 0.56 \mathrm{mmol})$ and $\mathrm{BF}_{3} \cdot \mathrm{OEt}_{2}(71 \mu \mathrm{L}$, $0.56 \mathrm{mmol})$ in $\mathrm{CH}_{2} \mathrm{Cl}_{2}(2 \mathrm{~mL})$, were reacted for $18 \mathrm{~h}$ according to general procedure $\mathrm{B}$ to afford 15aJ (44 mg, $0.15 \mathrm{mmol}, 53 \%$ ) as a colorless oil which was identical to the compound obtained from benzyl carbamate (14).

[1-(5-Oxo-2,5-dihydrofuran-2-yl)benzyl]carbamic acid benzyl ester (15aL) ${ }^{27}$ from 11. Carbamate 11 (100 mg, $0.28 \mathrm{mmol})$, 2-timethylsilyloxy-furan $(70 \mu \mathrm{L}, 0.42 \mathrm{mmol})$ and $\mathrm{BF}_{3} \cdot \mathrm{OEt}_{2}$ (34 $\mu \mathrm{L}, 0.28 \mathrm{mmol})$ in $\mathrm{CH}_{2} \mathrm{Cl}_{2}(1.5 \mathrm{~mL})$, were reacted for $1 \mathrm{~h}$ at at $-78{ }^{\circ} \mathrm{C}$, the mixture was allowed to warm up to $\mathrm{rt}$ and reacted for $18 \mathrm{~h}$ at this temperature according to general procedure B to afford 15aL (46 mg, $0.14 \mathrm{mmol}, 51 \%$ ) as a white solid. $R_{f} 0.74$ (EtOAc/PE 1:1). ${ }^{1} \mathrm{H}$ NMR $\left(400 \mathrm{MHz}, \mathrm{CDCl}_{3}\right) \delta 7.47(\mathrm{~m}, 11 \mathrm{H}, \mathrm{Ar}-\mathrm{H}$ and $\mathrm{COCH}=\mathrm{CH}), 6.09(\mathrm{dd}, J=2.0,5.7 \mathrm{~Hz}, 1 \mathrm{H}$, $\mathrm{COCH}=\mathrm{CH}), 5.34$ (br s, $1 \mathrm{H}, \mathrm{NH}), 5.14-5.03\left(\mathrm{~m}, 4 \mathrm{H}, \mathrm{ArCH}_{2}, \mathrm{NHCH}\right.$ and $\left.\mathrm{CH}=\mathrm{CHCH}\right) .{ }^{13} \mathrm{C}$ NMR $\left(100 \mathrm{MHz}_{\mathrm{CDCl}}\right) \delta 170.2(\mathrm{OCO}), 153.9(\mathrm{OCON}), 137.4,135.8,128.9,128.7,128.4,128.2$, 128.0, 127.0 (Ar-C), $122.6(\mathrm{COCH}=\mathrm{CH}), 110.5(\mathrm{COCH}=\mathrm{CH}), 84.7(\mathrm{CH}=\mathrm{CHCH}), 67.1\left(\mathrm{ArCH}_{2}\right)$, $55.7(\mathrm{NHCH})$. IR $v, \mathrm{~cm}^{-1} 3312,3034,1760,1702,1533,1247,1160,1052,819$. HRMS (FAB+) calculated for $\mathrm{C}_{19} \mathrm{H}_{18} \mathrm{NO}_{4}\left(\mathrm{M}^{+}+\mathrm{H}\right) 324.1236$, found 324.1240.

(1-(Furan-2-ylbenzyl)carbamic acid benzyl ester (15aM) from 11. Carbamate 11 (100 mg, $0.28 \mathrm{mmol})$ was dissolved in furan $(1.5 \mathrm{~mL})$, camphorsulfonic acid monohydrate (65 $\mathrm{mg}$, $0.28 \mathrm{mmol}$ ) was added and the reaction mixture was stirred for $18 \mathrm{~h}$ at $\mathrm{rt}$. Then, $10 \%$ aqueous $\mathrm{Na}_{2} \mathrm{CO}_{3}(3 \mathrm{~mL})$ was added and the layers were separated. The aqueous layer was extracted with $\mathrm{CH}_{2} \mathrm{Cl}_{2}(2 \times 2 \mathrm{~mL})$, the combined organic layers were washed with aqueous saturated $\mathrm{NaCl}$ $(5 \mathrm{~mL})$, dried $\left(\mathrm{MgSO}_{4}\right)$ and concentrated in vacuo. The crude product was purified using column chromatography (EtOAc/PE 1:2) to afford 15aM (47 mg, $0.15 \mathrm{mmol}, 55 \%)$ as a white solid. $R_{f}$ 0.56 (EtOAc/PE 1:1). ${ }^{1} \mathrm{H}$ NMR (400 MHz, $\left.\mathrm{CDCl}_{3}\right) \delta$ 7.39-7.28 (m, 11H, Ar-H) 6.31 (dd, $J=1.9$, $3.1 \mathrm{~Hz}, 1 \mathrm{H}$, furan), 6.15 (br s, $1 \mathrm{H}$, furan), 6.02 (br d, $J=7.6 \mathrm{~Hz}, 1 \mathrm{H}, \mathrm{NH}), 5.52$ (br s, $1 \mathrm{H}$, $\mathrm{NHCH}), 516-5.09\left(\mathrm{~m}, 2 \mathrm{H}, \mathrm{ArCH}_{2}\right) .{ }^{13} \mathrm{C} \mathrm{NMR}\left(100 \mathrm{MHz}, \mathrm{CDCl}_{3}\right) \delta 155.4(\mathrm{OCON}), 153.5,139.4$, 136.1, 128.5, 128.4, 128.0, 127.8, 126.8 (Ar-C), 110.2, 107.4 (furan), $67.0\left(\mathrm{ArCH}_{2}\right), 53.1$ $(\mathrm{NHCH})$. IR $v, \mathrm{~cm}^{-1} 3307,1689,1539,1248$. HRMS (FAB+) calculated for $\mathrm{C}_{19} \mathrm{H}_{18} \mathrm{NO}_{3}\left(\mathrm{M}^{+}+\mathrm{H}\right)$ 308.1287 , found 308.1280 . 
Benzyloxycarbonylaminophenylacetic acid (22). ${ }^{28}$ Furan 15aM (37 mg, $0.12 \mathrm{mmol}$ ) was dissolved in $\mathrm{MeOH}(2.5 \mathrm{~mL})$ and cooled to $-78^{\circ} \mathrm{C} . \mathrm{O}_{3}$ was bubbled through the cold solution until the reaction mixture turned blue, then some $\mathrm{O}_{2}$ was bubbled through until the reaction mixture turned colorless again. The solution was allowed to warm up to rt, concentrated in vacuo and purified using column chromatography (EtOAc/PE, 1:1, 10\% AcOH) to afford 22 (26 mg, $0.10 \mathrm{mmol}, 79 \%) .{ }^{1} \mathrm{H}$ NMR $\left(400 \mathrm{MHz}, \mathrm{CDCl}_{3}\right) \delta 7.88$ (br s, $\left.1 \mathrm{H}, \mathrm{CO}_{2} \mathrm{H}\right), 7.54-7.34$ (m, 10H, ArH), 5.87 (br d, $J=6.9 \mathrm{~Hz}, 1 \mathrm{H}, \mathrm{NH}), 5.39$ (d, $J=7.1 \mathrm{~Hz}, 1 \mathrm{H}, \mathrm{NHCH}), 5.10$ (s, 2H, $\operatorname{ArCH}_{2}$ ). ${ }^{13} \mathrm{C}$ NMR $\left(100 \mathrm{MHz}, \mathrm{CDCl}_{3}\right) \delta 174.3\left(\mathrm{CO}_{2} \mathrm{H}\right), 155.4(\mathrm{OCON}), 137.1,135.8,130.1,128.5,128.4$, 128.2, 128.1, 127.1 (Ar-C), $67.2\left(\mathrm{ArCH}_{2}\right), 57.7(\mathrm{NHCH}) . \mathrm{IR} v, \mathrm{~cm}^{-1} 3340,3032,1718,1498$, 1410, 1345, 1215, 1051. HRMS (EI+) calculated for $\mathrm{C}_{16} \mathrm{H}_{15} \mathrm{NO}_{4}\left(\mathrm{M}^{+}\right)$285.1001, found 285.1007.

\section{General procedure $\mathbf{C}$ for the three component reaction with resin $\mathbf{2 3}$}

SEC resin 23 was suspended in $\mathrm{CH}_{2} \mathrm{Cl}_{2}$. The aldehyde or acetal (3 equiv), nucleophile ( 3 equiv) and Lewis acid ( 1.5 equiv) were added. The reaction mixture was stirred at $\mathrm{rt}$ for the indicated time, filtered off, washed with $\mathrm{CH}_{2} \mathrm{Cl}_{2}$, EtOH (these steps were repeated four times) and $\mathrm{Et}_{2} \mathrm{O}(2 \times)$ and dried in vacuo. Then, the resin was suspended in THF/MeOH (2:1), $\mathrm{NaOMe}$ (3 equiv) was added and the suspension was stirred for $3 \mathrm{~h}$ at $\mathrm{rt}$. The reaction mixture was filtered off, the resin was washed with THF $(2 \times)$, neutralized with $\mathrm{HCl}$ and diluted with saturated aqueous $\mathrm{NaCl}$ solution. The layers were separated, the aqueous phase was extracted with EtOAc $(4 \times)$, and the collected organic phases were concentrated in vacuo. The product was purified using SPE chromatography (Isolute, silica, solvent system: $0 \rightarrow 10 \% \mathrm{MeOH}$ in $\mathrm{CH}_{2} \mathrm{Cl}_{2}$ ).

1-Phenylbut-3-enylamine (25aA). ${ }^{29}$ Resin 23 (150 mg, $0.17 \mathrm{mmol}$ ), benzaldehyde (52 $\mu \mathrm{L}$, $0.51 \mathrm{mmol})$, allyltrimethylsilane $(82 \mu \mathrm{L}, 0.51 \mathrm{mmol})$ and $\mathrm{BF}_{3} \cdot \mathrm{OEt}_{2}(32 \mu \mathrm{L}, 0.26 \mathrm{mmol})$ were reacted for $3 \mathrm{~h}$ according to general procedure $\mathrm{C}$ to afford resin 24aA. IR $v$ 3655, 3360, 1724. After subsequent cleavage and purification, 25aA (20 mg, $0.14 \mathrm{mmol}, 80 \%)$ was obtained as a colorless oil. $R_{f} 0.20\left(\mathrm{CH}_{2} \mathrm{Cl}_{2} / \mathrm{MeOH} 9: 1\right) .{ }^{1} \mathrm{H}$ NMR (400 MHz, $\left.\mathrm{CDCl}_{3}\right) \delta$ 7.34-7.22 (m, 5H, Ar$\mathrm{H})$, 5.81-5.70 (m, $\left.1 \mathrm{H}, \mathrm{CH}=\mathrm{CH}_{2}\right), 5.15-5.07\left(\mathrm{~m}, 2 \mathrm{H}, \mathrm{CH}=\mathrm{CH}_{2}\right), 3.99(\mathrm{dd}, J=8.0,5.4 \mathrm{~Hz}, 1 \mathrm{H}$, $\left.\mathrm{NH}_{2} \mathrm{CH}\right), 2.51-2.33\left(\mathrm{~m}, 2 \mathrm{H}, \mathrm{CH}_{2} \mathrm{CH}=\mathrm{CH}_{2}\right), 1.66\left(\right.$ br s, $\left.2 \mathrm{H}, \mathrm{NH}_{2}\right) .{ }^{13} \mathrm{C} \mathrm{NMR}\left(100 \mathrm{MHz}, \mathrm{CDCl}_{3}\right) \delta$ 148.6 (Ar-H), $133.6\left(\mathrm{CH}=\mathrm{CH}_{2}\right), 128.6,127.4,126.6(\mathrm{Ar}-\mathrm{C}), 118.6\left(\mathrm{CH}=\mathrm{CH}_{2}\right), 55.4\left(\mathrm{NH}_{2} \mathrm{CH}\right)$, $41.7\left(\mathrm{CH}_{2} \mathrm{CH}=\mathrm{CH}_{2}\right) . \mathrm{IR} \vee 3385,1642$. HRMS (EI) calculated for $\mathrm{C}_{10} \mathrm{H}_{13} \mathrm{~N}\left(\mathrm{M}^{+}\right) 147.1048$ found, 147.1037.

1-(4-Methoxyphenyl)but-3-enylamine (25bA). ${ }^{30}$ Resin $23 \quad(150 \quad \mathrm{mg}, \quad 0.17 \mathrm{mmol}), \quad p$ anisaldehyde $(62 \mu \mathrm{L}, 0.51 \mathrm{mmol})$, allyltrimethylsilane $(82 \mu \mathrm{L}, 0.51 \mathrm{mmol})$ and $\mathrm{BF}_{3} \cdot \mathrm{OEt}_{2}(32 \mu \mathrm{L}$, $0.26 \mathrm{mmol}$ ) were reacted for $3 \mathrm{~h}$ according to general procedure $\mathrm{C}$ to afford resin $24 \mathbf{b A}$. IR $v$ 3634, 3491, 1724. After subsequent cleavage and purification 25bA (24 mg, 0.14 mmol, 79\%) was obtained as a colorless oil. $R_{f} 0.13\left(\mathrm{CH}_{2} \mathrm{Cl}_{2} / \mathrm{MeOH} 9: 1\right) .{ }^{1} \mathrm{H} \mathrm{NMR}\left(400 \mathrm{MHz}, \mathrm{CDCl}_{3}\right) \delta 7.27$ (d, $J=8.7 \mathrm{~Hz}, 2 \mathrm{H}, \mathrm{Ar}-\mathrm{H}), 6.85$ (d, $J=8.5 \mathrm{~Hz}, 2 \mathrm{H}, \mathrm{Ar}-\mathrm{H}), 5.71-5.60\left(\mathrm{~m}, 1 \mathrm{H}, \mathrm{CH}=\mathrm{CH}_{2}\right), 5.11$ $5.03\left(\mathrm{~m}, 2 \mathrm{H}, \mathrm{CH}=\mathrm{CH}_{2}\right), 4.61$ (br s, $\left.2 \mathrm{H}, \mathrm{NH}_{2}\right), 3.99$ (dd, $\left.J=14.2,6.8 \mathrm{~Hz}, 1 \mathrm{H}, \mathrm{NH}_{2} \mathrm{CH}\right), 3.78(\mathrm{~s}$, $\left.3 \mathrm{H}, \mathrm{OCH}_{3}\right), 2.51\left(\mathrm{t}, J=7.0 \mathrm{~Hz}, 2 \mathrm{H}, \mathrm{CH}_{2} \mathrm{CH}=\mathrm{CH}_{2}\right)$. MS (ESI) calculated for $\mathrm{C}_{11} \mathrm{H}_{16} \mathrm{NO}\left(\mathrm{M}^{+}+\mathrm{H}\right)$ 178 , found 178 . 
1-(4-Cyanophenyl)but-3-enylamine $\quad$ (25cA). $\quad$ Resin $23 \quad(150 \quad \mathrm{mg}, \quad 0.17 \quad \mathrm{mmol}), \quad 4-$ cyanobenzaldehyde $(67 \mathrm{mg}, 0.51 \mathrm{mmol})$, allyltrimethylsilane $(82 \mu \mathrm{L}, 0.51 \mathrm{mmol})$ and $\mathrm{BF}_{3} \cdot \mathrm{OEt}_{2}$ (32 $\mu \mathrm{L}, 0.26 \mathrm{mmol}$ ) were reacted for $3 \mathrm{~h}$ according to general procedure $\mathrm{C}$ to afford resin $24 \mathbf{c A}$. IR $v$ 3637, 3501, 2229, 1723. After subsequent cleavage and purification 25cA (12 mg, $0.07 \mathrm{mmol}, 39 \%)$ was obtained as a colorless oil. $R_{f} 0.24\left(\mathrm{CH}_{2} \mathrm{Cl}_{2} / \mathrm{MeOH} 9: 1\right) .{ }^{1} \mathrm{H}$ NMR (400 $\left.\mathrm{MHz}, \mathrm{CDCl}_{3}\right) \delta 7.61(\mathrm{~d}, J=8.3 \mathrm{~Hz}, 2 \mathrm{H}, \mathrm{Ar}-\mathrm{H}), 7.46(\mathrm{~d}, J=8.2 \mathrm{~Hz}, 2 \mathrm{H}, \mathrm{Ar}-\mathrm{H})$, 5.76-5.65 (m, $\left.1 \mathrm{H}, \mathrm{CH}=\mathrm{CH}_{2}\right), 5.13-5.01\left(\mathrm{~m}, 2 \mathrm{H}, \mathrm{CH}=\mathrm{CH}_{2}\right), 4.07\left(\mathrm{dd}, J=7.6,5.6 \mathrm{~Hz}, 1 \mathrm{H}, \mathrm{NH}_{2} \mathrm{CH}\right), 2.47-2.29$ $\left(\mathrm{m}, 2 \mathrm{H}, \mathrm{CH}_{2} \mathrm{CH}=\mathrm{CH}_{2}\right), 1.60\left(\right.$ br s, $\left.2 \mathrm{H}, \mathrm{NH}_{2}\right) .{ }^{13} \mathrm{C} \mathrm{NMR}\left(100 \mathrm{MHz}, \mathrm{CDCl}_{3}\right) \delta 143.9$ (Ar-C) 132.2 $\left(\mathrm{CH}=\mathrm{CH}_{2}\right), 127.6,127.1$ (Ar-C), 119.1, $118.5\left(\mathrm{CN}, \mathrm{CH}=\mathrm{CH}_{2}\right)$ 111.2 (Ar-C), $55.6\left(\mathrm{NH}_{2} \mathrm{CH}\right), 42.1$ $\left(\mathrm{CH}_{2} \mathrm{CH}=\mathrm{CH}_{2}\right)$. IR $v, \mathrm{~cm}^{-1} 3339,2228,1641$. HRMS $(\mathrm{EI}+)$ calculated for $\mathrm{C}_{11} \mathrm{H}_{10} \mathrm{~N}\left(\mathrm{M}^{+}-\mathrm{NH}_{3}\right)$ 156.0813 found, 156.0821 .

1-(4-Nitrophenyl)but-3-enylamine (25dA). Resin $23 \quad(150 \quad \mathrm{mg}, \quad 0.17 \quad \mathrm{mmol}), \quad 4-$ nitrobenzaldehyde $(78 \mathrm{mg}, 0.51 \mathrm{mmol})$, allyltrimethylsilane $(82 \mu \mathrm{L}, 0.51 \mathrm{mmol})$ and $\mathrm{BF}_{3} \cdot \mathrm{OEt}_{2}$ ( $32 \mu \mathrm{L}, 0.26 \mathrm{mmol}$ ) were reacted for $3 \mathrm{~h}$ according to general procedure $\mathrm{C}$ to afford resin $24 \mathrm{dA}$. IR $\vee 3625,3505,1726,1523,1352$. After subsequent cleavage and purification 25dA (1 mg, $0.01 \mathrm{mmol},<3 \%)$ was obtained as a colorless oil. $R_{f} 0.17\left(\mathrm{CH}_{2} \mathrm{Cl}_{2} / \mathrm{MeOH} 9: 1\right)$. ${ }^{1} \mathrm{H}$ NMR $\left(400 \mathrm{MHz}, \mathrm{CDCl}_{3}\right) \delta 8.19(\mathrm{~d}, J=8.8 \mathrm{~Hz}, 2 \mathrm{H}, \mathrm{Ar}-\mathrm{H}), 7.52(\mathrm{~d}, J=8.7 \mathrm{~Hz}, 2 \mathrm{H}, \mathrm{Ar}-\mathrm{H})$, 5.75-5.67 $\left(\mathrm{m}, 1 \mathrm{H}, \mathrm{CH}=\mathrm{CH}_{2}\right), 5.30-5.06\left(\mathrm{~m}, 2 \mathrm{H}, \mathrm{CH}=\mathrm{CH}_{2}\right), 4.14\left(\mathrm{dd}, J=5.3,7.8 \mathrm{~Hz}, 1 \mathrm{H}, \mathrm{NH}_{2} \mathrm{CH}\right), 2.48-$ $2.32\left(\mathrm{~m}, 2 \mathrm{H}, \mathrm{CH}_{2} \mathrm{CH}=\mathrm{CH}_{2}\right), 1.75\left(\right.$ br s, $\left.2 \mathrm{H}, \mathrm{NH}_{2}\right) .{ }^{13} \mathrm{C} \mathrm{NMR}\left(100 \mathrm{MHz}, \mathrm{CDCl}_{3}\right) \delta 151.7,146.2$ (Ar-C), $134.0\left(\mathrm{CH}=\mathrm{CH}_{2}\right), 127.2,123.6$ (Ar-C), $118.6\left(\mathrm{CH}=\mathrm{CH}_{2}\right), 54.7\left(\mathrm{NH}_{2} \mathrm{CH}\right), 43.6$ $\left(\mathrm{CH}_{2} \mathrm{CH}=\mathrm{CH}_{2}\right)$. IR $v, \mathrm{~cm}^{-1} 3356,1598,1520,1345$. HRMS (EI+) calculated for $\mathrm{C}_{10} \mathrm{H}_{13} \mathrm{~N}_{2} \mathrm{O}_{2}\left(\mathrm{M}^{+}\right.$ $\left.-\mathrm{NH}_{3}\right) 193.0977$ found, 193.0974 .

1-(Thiophen-3-yl)but-3-enylamine (25iA). Resin 23 (150 mg, $0.19 \mathrm{mmol}$ ), 3-thiophene carboxaldehyde $(49 \mu \mathrm{L}, 0.56 \mathrm{mmol})$, allyltrimethylsilane $(89 \mu \mathrm{L}, 0.56 \mathrm{mmol})$ and $\mathrm{BF}_{3} \cdot \mathrm{OEt}_{2}(36 \mu \mathrm{L}$, $0.28 \mathrm{mmol})$ were reacted according to general procedure $\mathrm{C}$ to afford $25 \mathbf{i} \mathbf{A}(17 \mathrm{mg}, 0.11 \mathrm{mmol}$, $60 \%$ ) as a pale yellow oil. $R_{f} 0.15\left(\mathrm{CH}_{2} \mathrm{Cl}_{2} / \mathrm{MeOH} 9: 1\right) .{ }^{1} \mathrm{H} \mathrm{NMR}\left(400 \mathrm{MHz}, \mathrm{CDCl}_{3}\right) \delta 7.43(\mathrm{dd}$, $J=1.1,2.8 \mathrm{~Hz}, 1 \mathrm{H}, \mathrm{Ar}-\mathrm{H}), 7.31-7.21(\mathrm{~m}, 2 \mathrm{H}, \mathrm{Ar}-\mathrm{H}), 5.67-5.56\left(\mathrm{~m}, 1 \mathrm{H}, \mathrm{CH}=\mathrm{CH}_{2}\right), 5.16-5.09(\mathrm{~m}$, $\left.2 \mathrm{H}, \mathrm{CH}=\mathrm{CH}_{2}\right), 4.40-4.37\left(\mathrm{~m}, 1 \mathrm{H}, \mathrm{NH}_{2} \mathrm{CH}\right), 2.85-2.68\left(\mathrm{~m}, 2 \mathrm{H}, \mathrm{CH}_{2} \mathrm{CH}=\mathrm{CH}_{2}\right) .{ }^{13} \mathrm{C}$ NMR $(50$ $\left.\mathrm{MHz}, \mathrm{CDCl}_{3}\right) \delta 136.6,131.2,126.7,126.1,124.2\left(\mathrm{Ar}-\mathrm{C}\right.$ and $\left.\mathrm{CH}=\mathrm{CH}_{2}\right), 120.1\left(\mathrm{CH}=\mathrm{CH}_{2}\right), 51.0$ $\left(\mathrm{NH}_{2} \mathrm{CH}\right), 38.3\left(\mathrm{CH}_{2} \mathrm{CH}=\mathrm{CH}_{2}\right)$. IR $v, \mathrm{~cm}^{-1} 2908,1598,1509,1422,1087,994,924$. HRMS (EI+) calculated for $\mathrm{C}_{18} \mathrm{H}_{11} \mathrm{NS}\left(\mathrm{M}^{+}\right)$153.0612, found 153.0608 .

1-Benzylbut-3-enylamine (25fA). ${ }^{31}$ Resin 23 (200 mg, $\left.0.28 \mathrm{mmol}\right)$, phenylacetaldehyde diethyl acetal $(158 \mu \mathrm{L}, 1.12 \mathrm{mmol})$, allyltrimethylsilane $(179 \mu \mathrm{L}, 1.12 \mathrm{mmol})$ and $\mathrm{BF}_{3} \cdot \mathrm{OEt}_{2}(69 \mu \mathrm{L}$, $0.56 \mathrm{mmol}$ ) were reacted according to general procedure $\mathrm{C}$ to afford $25 \mathbf{f} \mathbf{A}(18 \mathrm{mg}, 0.11 \mathrm{mmol}$, $39 \%$ ) as a colorless oil. ${ }^{1} \mathrm{H}$ NMR $\left(400 \mathrm{MHz} \mathrm{CDCl}_{3}\right) \delta 7.33-7.23(\mathrm{~m}, 5 \mathrm{H}, \mathrm{Ar}-\mathrm{H})$, 5.89-5.79 (m, $\left.1 \mathrm{H}, \mathrm{CH}=\mathrm{CH}_{2}\right), 5.29-5.51\left(\mathrm{~m}, 2 \mathrm{H}, \mathrm{CH}=\mathrm{CH}_{2}\right), 3.53-3.46\left(\mathrm{~m}, 1 \mathrm{H}, \mathrm{NH}_{2} \mathrm{CH}\right), 3.23(\mathrm{dd}, J=5.4,13.7$ $\left.\mathrm{Hz}, 1 \mathrm{H}, \mathrm{ArCH}_{2}\right), 2.93\left(\mathrm{dd}, J=9.0,13.6 \mathrm{~Hz}, 1 \mathrm{H}, \mathrm{ArCH}_{2}\right), 2.47-2.43(\mathrm{t}, J=6.5 \mathrm{~Hz}, 2 \mathrm{H}$, $\left.\mathrm{CH}_{2} \mathrm{CH}=\mathrm{CH}_{2}\right) .{ }^{13} \mathrm{C} \mathrm{NMR}\left(100 \mathrm{MHz}, \mathrm{CDCl}_{3}\right) \delta 135.5,131.3,129.3,128.2,127.2$ (Ar-C and $\left.\mathrm{CH}=\mathrm{CH}_{2}\right), 120.9\left(\mathrm{CH}=\mathrm{CH}_{2}\right), 53.2\left(\mathrm{NH}_{2} \mathrm{CH}\right), 38.2,35.7\left(\mathrm{ArCH}_{2}\right.$ and $\left.\mathrm{CH}_{2} \mathrm{CH}=\mathrm{CH}_{2}\right) . \mathrm{IR} v, \mathrm{~cm}^{-1}$ 
3027, 2904, 1598, 1496, 1076, 996, 920. HRMS (EI+) calculated for $\mathrm{C}_{11} \mathrm{H}_{15} \mathrm{~N}\left(\mathrm{M}^{+}\right)$161.1204, found 161.1208.

1-Hexylbut-3-enylamine (25gA). ${ }^{32}$ Resin 23 (200 mg, $\left.0.28 \mathrm{mmol}\right)$, heptanal diethyl acetal (156 mg, $0.83 \mathrm{mmol}$ ), allyltrimethylsilane $(132 \mu \mathrm{L}, 0.83 \mathrm{mmol})$ and $\mathrm{BF}_{3} \cdot \mathrm{OEt}_{2}(51 \mu \mathrm{L}$, $0.41 \mathrm{mmol})$ were reacted according to general procedure $\mathrm{C}$ to afford $25 \mathrm{gA}(25 \mathrm{mg}, 0.16 \mathrm{mmol}$, $58 \%)$ as a colorless oil. ${ }^{1} \mathrm{H} \mathrm{NMR}\left(400 \mathrm{MHz} \mathrm{CDCl}_{3}\right) \delta 5.87-5.77\left(\mathrm{~m}, 1 \mathrm{H}, \mathrm{CH}=\mathrm{CH}_{2}\right), 5.26-5.21$ $\left(\mathrm{m}, 2 \mathrm{H}, \mathrm{CH}=\mathrm{CH}_{2}\right), 3.24-3.18\left(\mathrm{~m}, 1 \mathrm{H}, \mathrm{NH}_{2} \mathrm{CH}\right), 2.53-2.45\left(\mathrm{~m}, 2 \mathrm{H}, \mathrm{CH}_{2} \mathrm{CH}=\mathrm{CH}_{2}\right), 1.79-1.63(\mathrm{~m}$, $\left.2 \mathrm{H}, \mathrm{CHCH}_{2}\right), 1.48-1.22\left(\mathrm{~m}, 8 \mathrm{H},\left(\mathrm{CH}_{2}\right)_{4}\right), 0.88-0.85\left(\mathrm{~m}, 3 \mathrm{H}, \mathrm{CH}_{3}\right) .{ }^{13} \mathrm{C} \mathrm{NMR}\left(100 \mathrm{MHz}, \mathrm{CDCl}_{3}\right)$ $\delta 132.3\left(\mathrm{CH}=\mathrm{CH}_{2}\right), 120.2\left(\mathrm{CH}=\mathrm{CH}_{2}\right), 51.8\left(\mathrm{NH}_{2} \mathrm{CH}\right), 45.8,36.7,32.1,28.8,25.1,22.4$ $\left(\mathrm{CH}_{2} \mathrm{CH}=\mathrm{CH}_{2},\left(\mathrm{CH}_{2}\right)_{5}\right), 8.48\left(\mathrm{CH}_{3}\right) . \mathrm{IR} v, \mathrm{~cm}^{-1} 2952,2899,1605,1516,995$. HRMS (FAB +$)$ calculated for $\mathrm{C}_{13} \mathrm{H}_{30} \mathrm{NO}_{2} \mathrm{~S}\left(\mathrm{M}^{+}+\mathrm{H}+\right.$ thioglycerol) 264.1997, found 264.1993.

1-Cyclohexylbut-3-enylamine (25jA). ${ }^{33}$ Resin 23 (200 $\left.\mathrm{mg}, 0.28 \mathrm{mmol}\right)$, cyclohexane carboxaldehyde diethyl acetal (16j, $208 \mathrm{mg}, 1.12 \mathrm{mmol})$, allyltrimethylsilane (179 $\mu \mathrm{L}$, $1.12 \mathrm{mmol})$ and $\mathrm{BF}_{3} \cdot \mathrm{OEt}_{2}(69 \mu \mathrm{L}, 0.56 \mathrm{mmol})$ were reacted according to general procedure $\mathrm{C}$ to afford 25jA (15 mg, $0.10 \mathrm{mmol}, 35 \%)$ as a colorless oil. ${ }^{1} \mathrm{H}$ NMR $\left(400 \mathrm{MHz}, \mathrm{CDCl}_{3}\right) \delta 5.89$ $5.78\left(\mathrm{~m}, 1 \mathrm{H}, \mathrm{CH}=\mathrm{CH}_{2}\right), 5.28-5.19\left(\mathrm{~m}, 2 \mathrm{H}, \mathrm{CH}=\mathrm{CH}_{2}\right), 3.09-3.04\left(\mathrm{~m}, 1 \mathrm{H}, \mathrm{NH}_{2} \mathrm{CH}\right), 2.52-2.48(\mathrm{~m}$, $\left.2 \mathrm{H}, \mathrm{CH}_{2} \mathrm{CH}=\mathrm{CH}_{2}\right), 1.84-1.64(\mathrm{~m}, 6 \mathrm{H}, c-\mathrm{He}), 1.35-1.10(\mathrm{~m}, 5 \mathrm{H}, c-\mathrm{Hex}) .{ }^{13} \mathrm{C} \mathrm{NMR}(100 \mathrm{MHz}$, $\left.\mathrm{CDCl}_{3}\right) \delta 132.1\left(\mathrm{CH}=\mathrm{CH}_{2}\right), 119.8\left(\mathrm{CH}=\mathrm{CH}_{2}\right), 56.7\left(\mathrm{NH}_{2} \mathrm{CH}\right), 39.0(c-\mathrm{Hex}), 34.2,28.8,27.8$, 25.8, $25.7\left(\mathrm{CH}_{2} \mathrm{CH}=\mathrm{CH}_{2}\right.$ and $\left.c-\mathrm{Hex}\right)$. IR $v, \mathrm{~cm}^{-1} 2928,2854,1602,1515,1447,993$.

1-Styrylbut-3-enylamine (25kA). ${ }^{30}$ Resin 23 (200 mg, $\left.0.28 \mathrm{mmol}\right)$, (E)-cinnamaldehyde diethyl acetal $(171 \mathrm{mg}, 0.83 \mathrm{mmol})$, allyltrimethylsilane $(132 \mu \mathrm{L}, 0.83 \mathrm{mmol})$ and $\mathrm{BF}_{3} \cdot \mathrm{OEt}_{2}(51 \mu \mathrm{L}$, $0.41 \mathrm{mmol})$ were reacted according to general procedure $\mathrm{C}$ to afford 25kA (22 $\mathrm{mg}, 0.13 \mathrm{mmol}$, $46 \%$ ) as a colorless oil. ${ }^{1} \mathrm{H} \mathrm{NMR}\left(400 \mathrm{MHz}, \mathrm{CDCl}_{3}\right) \delta 7.37-7.21(\mathrm{~m}, 5 \mathrm{H}, \mathrm{Ar}-\mathrm{H}), 6.69(\mathrm{~d}, J=16.0$ $\mathrm{Hz}, 1 \mathrm{H}, \mathrm{PhCH}=\mathrm{CH}), 6.20(\mathrm{dd}, J=8.0,16.0 \mathrm{~Hz}, 1 \mathrm{H}, \mathrm{PhCH}=\mathrm{CH}), 5.74-5.63\left(\mathrm{~m}, 1 \mathrm{H}, \mathrm{CH}=\mathrm{CH}_{2}\right)$, 5.17-5.10 (m, 2H, $\left.\mathrm{CH}=\mathrm{CH}_{2}\right), 3.91-3.67\left(\mathrm{~m}, 1 \mathrm{H}, \mathrm{NH}_{2} \mathrm{CH}\right), 2.73-2.54\left(\mathrm{~m}, 2 \mathrm{H}, \mathrm{CH}_{2} \mathrm{CH}=\mathrm{CH}_{2}\right)$. ${ }^{13} \mathrm{C} \mathrm{NMR}\left(125 \mathrm{MHz}, \mathrm{CDCl}_{3}\right) \delta 135.8,135.5,131.4,128.6,128.4,126.9,123.8$ (Ar-C, $\mathrm{PhCH}=\mathrm{CH}$ and $\left.\mathrm{CH}=\mathrm{CH}_{2}\right) \quad 120.3\left(\mathrm{CH}=\mathrm{CH}_{2}\right), 53.8\left(\mathrm{NH}_{2} \mathrm{CH}\right), 37.8\left(\mathrm{CH}_{2} \mathrm{CH}=\mathrm{CH}_{2}\right) . \mathrm{IR} v, \mathrm{~cm}^{-1}$ 3383, 2980, 2884, 1601, 1495, 1073, 968, 922.

1-(4-Nitrophenyl)but-3-enylamine (25dA). Resin $23 \quad(200 \quad \mathrm{mg}, \quad 0.28 \quad \mathrm{mmol}), \quad 4-$ nitrobenzaldehyde diethyl acetal $(189 \mathrm{mg}, 0.83 \mathrm{mmol})$, allyltrimethylsilane (132 $\mu \mathrm{L}, 0.83 \mathrm{mmol})$ and $\mathrm{BF}_{3} \cdot \mathrm{OEt}_{2}(51 \mu \mathrm{L}, 0.41 \mathrm{mmol})$ were reacted according to general procedure $\mathrm{C}$ to afford $25 \mathbf{d A}$ (4 mg, $0.02 \mathrm{mmol}, 7 \%$ ) as a colorless oil which was identical to the product obtained with 4nitrobenzaldehyde (12d).

6-Amino-6-phenylhex-3-enoic acid methyl ester (25aG). Resin 23 (150 mg, $0.19 \mathrm{mmol}$ ), benzaldehyde $(57 \mu \mathrm{L}, 0.56 \mathrm{mmol})$, methyl 3-(trimethylsilyl)-4-pentenoate (116 $\mu \mathrm{L}, 0.56 \mathrm{mmol})$ and $\mathrm{BF}_{3} \cdot \mathrm{OEt}_{2}(36 \mu \mathrm{L}, 0.28 \mathrm{mmol})$ were reacted according to general procedure $\mathrm{C}$ to afford $25 \mathrm{aG}$ (17 mg, $0.08 \mathrm{mmol}, 42 \%)$ as a colorless oil. ${ }^{1} \mathrm{H} \mathrm{NMR}\left(400 \mathrm{MHz}, \mathrm{CDCl}_{3}\right) \delta 7.44-7.27(\mathrm{~m}, 5 \mathrm{H}$, Ar-H), 5.69-5.62 (m, $\left.1 \mathrm{H}, \mathrm{MeO}_{2} \mathrm{CCH}_{2} \mathrm{CH}=\mathrm{CH}\right), 5.42-5.30\left(\mathrm{~m}, 1 \mathrm{H}, \mathrm{MeO}_{2} \mathrm{CCH}_{2} \mathrm{CH}=\mathrm{CH}\right)$, 4.144.09 (m, 1H, $\mathrm{NH}_{2} \mathrm{CH}$ ), 3.62 (s, 3H, $\mathrm{CO}_{2} \mathrm{Me}$ ), 3.00 (d, J=6.8 Hz, 2H, $\mathrm{MeO}_{2} \mathrm{CCH}_{2}$ ), 2.69-2.60 (m, $\left.2 \mathrm{H}, \mathrm{CHCH}_{2}\right) .{ }^{13} \mathrm{C} \mathrm{NMR}\left(100 \mathrm{MHz}, \mathrm{CDCl}_{3}\right) \delta 172.1\left(\mathrm{CO}_{2} \mathrm{Me}\right), 128.9,128.7,127.5,127.1,126.7$ 
(Ar-C and $2 \times \mathrm{CH}=\mathrm{CH}), 55.6\left(\mathrm{CO}_{2} \mathrm{Me}\right), 51.7\left(\mathrm{NH}_{2} \mathrm{CH}\right), 39.2,37.5\left(\mathrm{MeO}_{2} \mathrm{CCH}_{2}\right.$ and $\left.\mathrm{CHCH}_{2}\right)$. IR $v, \mathrm{~cm}^{-1} 3250,2946,1722,1602,1509,1437,1256,1198,1167$. HRMS (FAB+) calculated for $\mathrm{C}_{13} \mathrm{H}_{18} \mathrm{NO}_{2}\left(\mathrm{M}^{+}+\mathrm{H}\right) 200.1338$, found 200.1346.

2-Methylene-1-phenylbut-3-enylamine (25aJ). Resin 23 (150 mg, $0.19 \mathrm{mmol}$ ), benzaldehyde $(57 \mu \mathrm{L}, 0.56 \mathrm{mmol})$, (allenylmethyl)trimethylsilane $(90 \mu \mathrm{L}, 0.56 \mathrm{mmol})$ and $\mathrm{BF}_{3} \cdot \mathrm{OEt}_{2}(36 \mu \mathrm{L}$, $0.28 \mathrm{mmol}$ ) were reacted according to general procedure $\mathrm{C}$ to afford 25aJ (18 $\mathrm{mg}, 0.06 \mathrm{mmol}$, $30 \%)$ as a colorless oil. $R_{f} 0.23\left(\mathrm{CH}_{2} \mathrm{Cl}_{2} / \mathrm{MeOH} 9: 1\right) .{ }^{1} \mathrm{H} \mathrm{NMR}\left(400 \mathrm{MHz}, \mathrm{CDCl}_{3}\right) \delta$ 7.43-7.31 (m, 5H, Ar-H), $6.84\left(\mathrm{dd}, J=11.7,22.5 \mathrm{~Hz}, 1 \mathrm{H}, \mathrm{CH}_{2}=\mathrm{CH}\right), 5.39\left(\mathrm{~d}, J=18.4 \mathrm{~Hz}, 2 \mathrm{H},=\mathrm{CH}_{2}\right)$, 5.04-4.98 (m, 3H, $=\mathrm{CH}_{2}$ and $\left.\mathrm{NH}_{2} \mathrm{CH}\right) .{ }^{13} \mathrm{C} \mathrm{NMR}\left(100 \mathrm{MHz}, \mathrm{CDCl}_{3}\right) \delta 141.2,135.0(\mathrm{Ar}-\mathrm{C}$ and $\left.\mathrm{CH}_{2}=\mathrm{C}\right), 135.3\left(\mathrm{CH}_{2}=\mathrm{CH}\right), 129.0,128.9,128.1(\mathrm{Ar}-\mathrm{C}), 117.4,116.2\left(=\mathrm{CH}_{2}\right), 55.7\left(\mathrm{NH}_{2} \mathrm{CH}\right) . \mathrm{IR}$ $v, \mathrm{~cm}^{-1}$ 2894, 2709, 1599, 1519, 1073, 1029, 908.

6-Amino-6-(4-methoxyphenyl)hex-3-enoic acid methyl ester (25bG). Resin 23 (150 mg, $0.19 \mathrm{mmol})$, 4-methoxybenzaldehyde $(68 \mu \mathrm{L}, 0.56 \mathrm{mmol})$, methyl 3-(trimethylsilyl)-4pentenoate $(116 \mu \mathrm{L}, 0.56 \mathrm{mmol})$ and $\mathrm{BF}_{3} \cdot \mathrm{OEt}_{2}(36 \mu \mathrm{L}, 0.28 \mathrm{mmol})$ were reacted according to general procedure $\mathrm{C}$ to afford 25bG (17 mg, $0.07 \mathrm{mmol}, 37 \%)$ as a colorless oil. ${ }^{1} \mathrm{H}$ NMR (400 $\left.\mathrm{MHz} \mathrm{CDCl}_{3}\right) \delta 7.45(\mathrm{~d}, J=8.7 \mathrm{~Hz}, 2 \mathrm{H}, \mathrm{Ar}-\mathrm{H}), 6.88(\mathrm{~d}, J=8.8 \mathrm{~Hz}, 2 \mathrm{H}, \mathrm{Ar}-\mathrm{H}), 5.72-5.64(\mathrm{~m}$, $\left.1 \mathrm{H}, \mathrm{MeO}_{2} \mathrm{CCH}_{2} \mathrm{CH}=\mathrm{CH}\right), 5.34-5.26\left(\mathrm{~m}, 1 \mathrm{H}, \mathrm{MeO}_{2} \mathrm{CCH}_{2} \mathrm{CH}=\mathrm{CH}\right), 4.15$ (br s, $1 \mathrm{H}, \mathrm{NH}_{2} \mathrm{CH}$ ), 3.77, $3.66\left(\mathrm{CO}_{2} \mathrm{Me}\right.$ and $\left.\mathrm{OMe}\right), 2.98$ (d, $\left.J=7.0 \mathrm{~Hz}, 2 \mathrm{H}, \mathrm{MeO}_{2} \mathrm{CCH}_{2}\right), 2.44-2.21\left(\mathrm{~m}, 2 \mathrm{H}, \mathrm{CHCH}_{2}\right)$. ${ }^{13} \mathrm{C}$ NMR $\left(100 \mathrm{MHz}, \mathrm{CDCl}_{3}\right) \delta 170.6\left(\mathrm{CO}_{2} \mathrm{Me}\right), 159.8,129.4,128.7,127.8,126.0,114.2(\mathrm{Ar}-\mathrm{C}$ and $2 \times \mathrm{CH}=\mathrm{CH}), 55.2,55.1,52.0\left(\mathrm{CO}_{2} \mathrm{Me}, \mathrm{NH}_{2} \mathrm{CH}\right.$ and $\left.\mathrm{OMe}\right), 37.5,36.1\left(\mathrm{MeO}_{2} \mathrm{CCH}_{2}\right.$ and $\left.\mathrm{CHCH}_{2}\right)$. IR $v, \mathrm{~cm}^{-1} 3384,2958,1734,1614,1518,1253,1182,1031$. HRMS (FAB+) calculated for $\mathrm{C}_{12} \mathrm{H}_{17} \mathrm{NO}\left(\mathrm{M}^{+} \mathrm{C}_{2} \mathrm{H}_{2} \mathrm{O}_{2}\right)$ 190.1310, found 190.1218.

1-(4-Methoxyphenyl)-2-methylenebut-3-enylamine (25bJ). Resin 23 (150 mg, 0.19 mmol), 4methoxybenzaldehyde $(68 \mu \mathrm{L}, 0.56 \mathrm{mmol})$, (allenylmethyl)trimethylsilane (90 $\mu \mathrm{L}, 0.56 \mathrm{mmol}$ ) and $\mathrm{BF}_{3} \cdot \mathrm{OEt}_{2}(36 \mu \mathrm{L}, 0.28 \mathrm{mmol})$ were reacted according to general procedure $\mathrm{C}$ to afford $\mathbf{2 5 \mathbf { b } \mathbf { J }}$ (17 mg, $0.09 \mathrm{mmol}, 48 \%$ ) as a colorless oil. $R_{f} 0.18\left(\mathrm{CH}_{2} \mathrm{Cl}_{2} / \mathrm{MeOH}\right.$ 9:1). ${ }^{1} \mathrm{H} \mathrm{NMR}(400 \mathrm{MHz}$, $\left.\mathrm{CDCl}_{3}\right) \delta 7.35(\mathrm{~d}, J=7.9 \mathrm{~Hz}, 2 \mathrm{H}, \mathrm{Ar}-\mathrm{H}), 6.83$ (d, $\left.J=7.9 \mathrm{~Hz}, 2 \mathrm{H}, \mathrm{Ar}-\mathrm{H}\right), 6.19$ (dd $J=11.2,17.6$ $\left.\mathrm{Hz}, 1 \mathrm{H}, \mathrm{CH}=\mathrm{CH}_{2}\right), 5.31\left(\mathrm{~d}, J=33.7 \mathrm{~Hz}, 2 \mathrm{H},=\mathrm{CH}_{2}\right), 5.03-4.96\left(\mathrm{~m}, 3 \mathrm{H}, \mathrm{NH}_{2} \mathrm{CH}_{2}\right.$ and $\left.=\mathrm{CH}_{2}\right), 3.77$ $(\mathrm{s}, 3 \mathrm{H}, \mathrm{OMe}) .{ }^{13} \mathrm{C} \mathrm{NMR}\left(50 \mathrm{MHz}, \mathrm{CDCl}_{3}\right) \delta 159.9(\mathrm{Ar}-\mathrm{C}), 140.7\left(\mathrm{C}=\mathrm{CH}_{2}\right), 135.2\left(\mathrm{CH}=\mathrm{CH}_{2}\right)$, 129.6, 126.3 (Ar-C), 117.3, $116.0\left(2 \times=\mathrm{CH}_{2}\right), 114.1$ (Ar-C), 55.1, 55.0 $\left(\mathrm{NH}_{2} \mathrm{CH}, \mathrm{OMe}\right) . \mathrm{IR} v, \mathrm{~cm}^{-1}$ 3220, 3031, 1616, 1519, 1466, 1257, 1182, 1035, 908, 835. HRMS (EI+) calculated for $\mathrm{C}_{12} \mathrm{H}_{15} \mathrm{NO}\left(\mathrm{M}^{+}\right)$189.1154, found 189.1154.

6-Amino-6-thiophen-3-ylhex-3-enoic acid methyl ester (25iG). Resin 23 (150 mg, $0.19 \mathrm{mmol}$ ), 3-thiophene carboxaldehyde (49 $\mu \mathrm{L}, 0.56 \mathrm{mmol}$ ), methyl 3-(trimethylsilyl)-4pentenoate $(116 \mu \mathrm{L}, 0.56 \mathrm{mmol})$ and $\mathrm{BF}_{3} \cdot \mathrm{OEt}_{2}(36 \mu \mathrm{L}, 0.28 \mathrm{mmol})$ were reacted according to general procedure $\mathrm{C}$ to afford $25 \mathrm{iG}(15 \mathrm{mg}, 0.07 \mathrm{mmol}, 36 \%)$ as a colorless oil. ${ }^{1} \mathrm{H}$ NMR $\left(400 \mathrm{MHz}, \mathrm{CDCl}_{3}\right) \delta 7.45(\mathrm{~d}, J=2.6 \mathrm{~Hz}, 1 \mathrm{H}, \mathrm{Ar}-\mathrm{H}), 7.31(\mathrm{dd}, J=2.8,4.9 \mathrm{~Hz}, 1 \mathrm{H}, \mathrm{Ar}-\mathrm{H}), 7.23$ $(\mathrm{d}, J=5.3 \mathrm{~Hz}, 1 \mathrm{H}, \mathrm{Ar}-\mathrm{H}), 5.74-5.68\left(\mathrm{~m}, 1 \mathrm{H}, \mathrm{MeO}_{2} \mathrm{CCH}_{2} \mathrm{CH}=\mathrm{CH}\right), 5.43-5.35(\mathrm{~m}, 1 \mathrm{H}$, $\mathrm{MeO}_{2} \mathrm{CCH}_{2} \mathrm{CH}=\mathrm{CH}$ ), 4.41 (br s, $\left.1 \mathrm{H}, \mathrm{NH}_{2} \mathrm{CH}\right), 3.63$ (s, 3H, $\mathrm{CO}_{2} \mathrm{Me}$ ), 3.03 (d, $J=6.8 \mathrm{~Hz}$, $\left.\mathrm{MeO}_{2} \mathrm{CCH}_{2}\right), 2.86-2.69\left(\mathrm{~m}, 2 \mathrm{H}, \mathrm{CHCH}_{2}\right) .{ }^{13} \mathrm{C} \mathrm{NMR}\left(100 \mathrm{MHz}, \mathrm{CDCl}_{3}\right) \delta 172.2\left(\mathrm{CO}_{2} \mathrm{Me}\right), 136.5$, 
127.8, 127.1, 126.0, 124.3, $122.2($ Ar- $\mathrm{C}$ and $\mathrm{CH}=\mathrm{CH}), 52.3,50.8\left(\mathrm{NH}_{2} \mathrm{CH}\right.$ and $\left.\mathrm{CO}_{2} \mathrm{Me}\right), 37.5$, $37.2\left(\mathrm{MeO}_{2} \mathrm{CCH}_{2}\right.$ and $\left.\mathrm{CHCH}_{2}\right)$. IR $v, \mathrm{~cm}^{-1} 3232,2984,1718,1637,1509,1438,1284,1206,974$. HRMS (FAB+) calculated for $\mathrm{C}_{11} \mathrm{H}_{16} \mathrm{NO}_{2} \mathrm{~S}\left(\mathrm{M}^{+}+\mathrm{H}\right) 226.0902$, found 226.0907.

2-Methylene-1-thiophen-3-ylbut-3-enylamine (25iJ). Resin 23 (150 mg, 0.19 mmol), 3thiophene carboxaldehyde $(49 \mu \mathrm{L}, 0.56 \mathrm{mmol})$, (allenylmethyl)trimethylsilane $(90 \mu \mathrm{L}$, $0.56 \mathrm{mmol})$ and $\mathrm{BF}_{3} \cdot \mathrm{OEt}_{2}(36 \mu \mathrm{L}, 0.28 \mathrm{mmol})$ were reacted according to general procedure $\mathrm{C}$ to afford 25iJ (18 mg, $0.08 \mathrm{mmol}, 36 \%)$ as a colorless oil. ${ }^{1} \mathrm{H} \mathrm{NMR}\left(400 \mathrm{MHz}, \mathrm{CDCl}_{3}\right) \delta 7.44(\mathrm{~s}$, $1 \mathrm{H}, \mathrm{Ar}-\mathrm{H}), 7.27$ (d, $J=5.0 \mathrm{~Hz}, 1 \mathrm{H}, \mathrm{Ar}-\mathrm{H}), 7.16(\mathrm{~d}, J=4.9 \mathrm{~Hz}, 1 \mathrm{H}, \mathrm{Ar}-\mathrm{H}), 6.28$ (dd, $J=11.2$, 17.7 Hz, $\left.1 \mathrm{H}, \mathrm{CH}=\mathrm{CH}_{2}\right), 5.51-5.08\left(\mathrm{~m}, 5 \mathrm{H}, \mathrm{CH}=\mathrm{CH}_{2}, \mathrm{C}=\mathrm{CH}_{2}\right.$ and $\left.\mathrm{NH}_{2} \mathrm{CH}\right) .{ }^{13} \mathrm{C} \mathrm{NMR}(50 \mathrm{MHz}$, $\left.\mathrm{CDCl}_{3}\right) \delta 141.3\left(\mathrm{C}=\mathrm{CH}_{2}\right), 135.5(\mathrm{Ar}-\mathrm{C}), 134.9\left(\mathrm{CH}=\mathrm{CH}_{2}\right), 126.8,126.5,125.4$ (Ar-C), 117.3, $116.2\left(\mathrm{C}=\mathrm{CH}_{2}\right.$ and $\left.\mathrm{CH}=\mathrm{CH}_{2}\right), 50.5\left(\mathrm{NH}_{2} \mathrm{CH}\right) . \mathrm{IR} v, \mathrm{~cm}^{-1} 3032,2884,1599,1515,1419,1235$, 1082, 996, 907. HRMS (EI+) calculated for $\mathrm{C}_{9} \mathrm{H}_{11} \mathrm{NS}\left(\mathrm{M}^{+}\right)$165.0612, found 165.0617.

(1-Benzotriazolylphenylmethyl)carbamic acid 2-sulfonylethyl ester resin (26a). Resin 23 (1.00 g, $1.38 \mathrm{mmol})$ was suspended in toluene $(10 \mathrm{~mL})$, benzaldehyde (421 $\mu \mathrm{L}, 4.14 \mathrm{mmol}), 1$ H-benzotriazole (493 mg, $4.14 \mathrm{mmol}$ ) and $p \mathrm{TsOH}(39 \mathrm{mg}, 0.21 \mathrm{mmol}$ ) were added and heated to reflux temperature. The reflux condensor was placed on top of a pressure-equalizing dropping funnel filled with $4 \AA \mathrm{MS}$ and the mixture was refluxed for $18 \mathrm{~h}$. The suspension was filtered, the resin was washed with $\mathrm{CH}_{2} \mathrm{Cl}_{2}(10 \mathrm{~mL}), \mathrm{EtOH}(2 \mathrm{~mL}$, the last two steps were repeated four times) and $\mathrm{Et}_{2} \mathrm{O}(2 \times 10 \mathrm{~mL})$. After drying in vacuo $\left(50^{\circ} \mathrm{C}\right)$ resin 26a was obtained. IR v 3560, 3023, 2919, 2852, 1728, 1601, 1492, 1310, 1118.

1-Phenylbut-3-enylamine (25aA) from resin 26a. Resin 26a (150 mg, 0.16 mmol), allyltrimethylsilane $(51 \mu \mathrm{L}, 0.32 \mathrm{mmol})$ and $\mathrm{BF}_{3} \cdot \mathrm{OEt}_{2}(39 \mu \mathrm{L}, 0.32 \mathrm{mmol})$ were reacted according to general procedure $\mathrm{C}$ to afford $25 \mathrm{aA}(17 \mathrm{mg}, 0.11 \mathrm{mmol}, 71 \%$ from resin 23 ) as a colorless oil which was identical to the product obtained directly from resin 23.

1-(Furan-2-yl)benzylamine $(25 a M)^{30}$ from resin 26a. Resin 26a (150 mg, $0.16 \mathrm{mmol}$ ) and camphersulfonic acid monohydrate $(76 \mathrm{mg}, 0.32 \mathrm{mmol})$ were suspended in furan $(1.5 \mathrm{~mL})$ and were reacted according to general procedure $\mathrm{C}$ to afford $25 \mathrm{aM}(14 \mathrm{mg}, 0.08 \mathrm{mmol}, 50 \%$ from resin 23) as a colorless oil. $R_{f} 0.41\left(\mathrm{CH}_{2} \mathrm{Cl}_{2} / \mathrm{MeOH} 9: 1\right) .{ }^{1} \mathrm{H} \mathrm{NMR}\left(400 \mathrm{MHz}, \mathrm{CDCl}_{3}\right) \delta 7.46-$ $7.27(\mathrm{~m}, 6 \mathrm{H}, \mathrm{Ar}-\mathrm{H}), 6.30$ (dd, $J=1.8,3.1 \mathrm{~Hz}, 1 \mathrm{H}$, furan), $6.10(\mathrm{~d}, J=3.2 \mathrm{~Hz}, 1 \mathrm{H}$, furan), 5.18 (s, $\left.1 \mathrm{H}, \mathrm{NH}_{2} \mathrm{CH}\right) .{ }^{13} \mathrm{C} \mathrm{NMR}\left(100 \mathrm{MHz}, \mathrm{CDCl}_{3}\right) \delta 148.9,134.1,129.1,128.9,128.1$, (Ar-C and furan), 110.6, 109.7 (furan), $53.0\left(\mathrm{NH}_{2} \mathrm{CH}\right) . \mathrm{IR} v, \mathrm{~cm}^{-1} 3169,2933,2819,1743,1619,1526$, 1187, 1042. HRMS (EI+) calculated for $\mathrm{C}_{11} \mathrm{H}_{11} \mathrm{NO}\left(\mathrm{M}^{+}\right)$173.0841, found 173.0838.

2-(2,4-Dimethoxyphenyl)benzylamine (25aN) from resin 26a. Resin 26a (100 mg, $0.11 \mathrm{mmol})$ and camphorsulfonic acid monohydrate $(51 \mathrm{mg}, 0.22 \mathrm{mmol})$ were suspended in 1,3dimethoxybenzene $(1.0 \mathrm{~mL})$ and were reacted according to general procedure $\mathrm{C}$ to afford $25 \mathrm{aN}$ ( $5 \mathrm{mg}, 0.02 \mathrm{mmol}, 20 \%$ from resin 23) as a colorless oil. $R_{f} 0.15\left(\mathrm{CH}_{2} \mathrm{Cl}_{2} / \mathrm{MeOH} 9: 1\right) .{ }^{1} \mathrm{H} \mathrm{NMR}$ $\left(400 \mathrm{MHz}, \mathrm{CDCl}_{3}\right) \delta$ 7.41-7.11 (m, 6H, Ar-H), 6.44-6.41 (m, 2H, Ar-H), $5.45\left(\mathrm{~s}, 1 \mathrm{H}, \mathrm{NH}_{2} \mathrm{CH}\right)$, 3.78 (2, 3H, OMe), 3.77 (s, 3H, OMe). ${ }^{13} \mathrm{C} \mathrm{NMR}\left(100 \mathrm{MHz}, \mathrm{CDCl}_{3}\right), 160.0,157.6,130.0,129.4$, 128.9, 127.7, 127.6, 125.7, 104.0, 98.7 (Ar-C), 55.3, $55.2(\mathrm{OMe}), 53.6\left(\mathrm{NH}_{2} \mathrm{CH}\right) . \mathrm{IR} v, \mathrm{~cm}^{-1}$ 
3361, 3007, 2935, 1612, 1587, 1454, 1293, 1209, 1034. HRMS (FAB+) calculated for $\mathrm{C}_{14} \mathrm{H}_{21} \mathrm{~N}_{2} \mathrm{O}_{5}\left(\mathrm{M}^{+}+\mathrm{H}\right) 297.1450$, found 297.1459.

1-(4-Nitrophenyl)but-3-enylamine (25dA) via Bt-derivative 26d. Resin 23 (1.00 g, $1.38 \mathrm{mmol})$ was suspended in toluene $(10 \mathrm{~mL})$, 4-nitrobenzaldehyde (421 $\mu \mathrm{L}, 4.14 \mathrm{mmol}), 1-\mathrm{H}-$ benzotriazole (493 mg, $4.14 \mathrm{mmol}$ ) and $\mathrm{pTsOH}(39 \mathrm{mg}, 0.21 \mathrm{mmol}$ ) were added and heated to reflux temperature. The reflux condensor was placed on top of a pressure-equalizing dropping funnel filled with $4 \AA \mathrm{MS}$ and the mixture was refluxed for $18 \mathrm{~h}$. The suspension was filtered, the resin was washed with $\mathrm{CH}_{2} \mathrm{Cl}_{2}(10 \mathrm{~mL}), \mathrm{EtOH}(2 \mathrm{~mL}$, the last two steps were repeated four times) and $\mathrm{Et}_{2} \mathrm{O}(2 \times 10 \mathrm{~mL})$. After drying in vacuo $\left(50^{\circ} \mathrm{C}\right)$ resin $\mathbf{2 6 d}$ was obtained. IR v 3545 , 3018, 2957, 1726, 1524, 1353. Resin 26d (150 mg, $0.16 \mathrm{mmol})$, allyltrimethylsilane $(51 \mu \mathrm{L}$, $0.32 \mathrm{mmol})$ and $\mathrm{BF}_{3} \cdot \mathrm{OEt}_{2}(40 \mu \mathrm{L}, 0.32 \mathrm{mmol})$ were reacted according to general procedure $\mathrm{C}$ to afford 25dA (15 mg, $0.78 \mathrm{mmol}, 49 \%$ from resin 23) as a colorless oil which was identical to the product obtained directly from resin 23.

\section{Acknowledgements}

This research has been financially supported (in part) by the Council for Chemical Sciences of the Netherlands Organization for Scientific Research (CW-NWO).

\section{References and Notes}

1. For reviews, see e.g.: (a) Dörwald, F. Z. Organic Synthesis on Solid Phase: Supports, linkers, reactions; Wiley-VCH: Weinheim, 2000. (b) Krchnak, V.; Holladay, M. W. Chem. Rev. 2002, 102, 61. (c) Guillier, F.; Orain, D.; Bradley, M. Chem. Rev. 2000, 100, 2091. (d) Balkenhohl, F.; von dem Bussche-Hünnefeld, C.; Lansky, A.; Zechel, C. Angew. Chem. Int. Ed. 1996, 35, 2288.

2. Meester, W. J. N.; Rutjes, F. P. J. T.; Hermkens, P. H. H.; Hiemstra, H. Tetrahedron Lett. 1999, 40, 1601.

3. Veerman, J. J. N.; Rutjes, F. P. J. T.; Van Maarseveen, J. H.; Hiemstra, H. Tetrahedron Lett. 1999, 40, 6079.

4. Van Maarseveen, J. H.; Meester, W. J. N.; Veerman, J. J. N.; Kruse, C. G.; Hermkens, P. H. H.; Rutjes, F. P. J. T.; Hiemstra, H. J. Chem. Soc., Perkin Trans. 1 2001, 994.

5. Veerman, J. J. N.; Klein, J.; Aben, R. W. M.; Scheeren, H. W.; Kruse, C. G.; Van Maarseveen, J. H.; Hiemstra, H.; Rutjes, F. P. J. T. Eur. J. Org. Chem. 2002, 3133.

6. (a) Vojkovsky, T.; Weichsel, A.; Patek, M. J. Org. Chem. 1998, 63, 3162. (b) Wang, H. S.; Ganesan, A. Org. Lett. 1999, 1, 1647. (c) Brown, R. C. D.; Fisher, M. Chem. Commun. 1999, 1547. (d) Valverde, M. G.; Dallinger, D.; Kappe, C. O. Synlett 2001, 741. (e) Schunk, S.; Enders, D. Org. Lett. 2001, 3, 3177 (f) Sun, H.; Moeller, K. D. Org. Lett. 2003, 5, 3189.

7. Panek, J. S.; Jain, N. F. J. Org. Chem. 1994, 59, 2674. 
8. Veenstra, S. J.; Schmid, P. Tetrahedron Lett. 1997, 38, 997.

9. For recent syntheses of homoallylic amines, see for example: (a) Masuyama, Y.; Tosa, J.; Kurusu, Y. Chem. Commun. 1999, 1075. (b) Itsuno, S.; Watanabe, K.; Matsumoto, T.; Kuroda, S.; Yokoi, A.; El-Shehawy, A. J. Chem. Soc., Perkin Trans. 1 1999, 2011. (c) Watanabe, K.; Kuroda, S.; Yokoi, A.; Ito, K.; Itsuno, S. J. Organomet. Chem. 1999, 581, 103. (d) Niimi, L.; Serita, K.; Hiraoka, S.; Yokozawa, T. Tetrahedron Lett. 2000, 41, 7075. (e) Roux, M.; Santelli, M.; Parrain, J. -L. Org. Lett. 2000, 2, 1701. (f) Schaus, J. V.; Jain, N.; Panek, J. S. Tetrahedron 2000, 56, 10263. (g) Billet, M.; Klotz, P.; Mann, A. Tetrahedron Lett. 2001, 42, 631. (h) Neipp, C. E.; Humphrey, J. M.; Martin. S. F. J. Org. Chem. 2001, 66, 531. (i) van der Sluis, M.; Dalmolen, J.; de Lange, B.; Kaptein, B.; Kellogg, R. M.; Broxterman, Q. B. Org. Lett. 2001, 3, 3943. (j) Wipf P.; Kendall, C. Org. Lett. 2001, 3, 2773. (k) Friestad, G. K.; Ding. H. Angew. Chem. Int. Ed. 2001, 40, 4491. (1) Sugiura, M.; Hagio, H.; Hirabayashi, R.; Kobayashi, S. J. Am. Chem. Soc. 2001, 123, 12510. (m) Itsuno, S.; Watanabe, K.; El-Shehawy, A. A. Adv. Synth. Catal. 2001, 343, 89. (n) Schunk, S.; Enders, D. Org. Lett. 2001, 3, 3177.

10. Vanier, C.; Wagner, A.; Mioskowski, C. Chem. Eur. J. 2001, 7, 2318.

11. (a) Roos, E. C.; Mooiweer, H. H.; Hiemstra, H.; Speckamp, W. N.; Kaptein, B. J. Org. Chem. 1992, 57, 6769. (b) Kimbonguila, A. M.; Merzouk, A.; Guibé, F.; Loffet, A. Tetrahedron 1999, 55, 6931.

12. (a) Katritzky, A. R.; Yannakopoulou, K. Synthesis 1989, 747. (b) Katritzky, A. R.; Urogdi, L.; Mayence, A. J. Org. Chem. 1990, 55, 2206.

13. For reviews on benzotriazole, see: (a) Katritzky, A. R.; Rachwal, S.; Hitchings, G. J. Tetrahedron 1991, 47, 2683. (b) Katritzky, A. R.; Lan, X.; Fan, W. -Q. Synthesis 1994, 445. (c) Katritzky, A. R.; Lan, X.; Yang, J. Z.; Denisko, O. V. Chem. Rev. 1998, 98, 409. (d) Katritzky, A. R. J. Heterocycl. Chem. 1999, 36, 1501.

14. (a) Prasad, S. J.; Liebeskind, L. S. Tetrahedron Lett. 1988, 29, 4253. (b) Prasad, S. J.; Liebeskind, L. S. Tetrahedron Lett. 1988, 29, 4257. (c) Karstens, W. F. J.; Rutjes, F. P. J. T.; Hiemstra, H. Tetrahedron Lett. 1997, 38, 6275.

15. For some recent examples of the use of $\mathrm{Me}_{3} \mathrm{SiCN}$ in $\mathrm{N}$-acyliminium ion chemistry, see: (a) Agami, C.; Amiot, F.; Couty, F.; Dechoux, L.; Kaminsky, C.; Venier, O. Tetrahedron: Asymmetry 1998, 9, 3955. (b) Lennartz, M.; Sadakane, M.; Steckhan, E. Tetrahedron 1999, 55, 14407. (c) Sugiura, M.; Kobayashi, S. Org. Lett. 2001, 3, 477. (d) For N-sulfonyliminium ions, see: Tjen, K. C. M. F.; Kinderman, S. S.; Schoemaker, H. E.; Hiemstra, H.; Rutjes, F. P. J. T. Chem. Commun. 2000, 699. (e) Vink, M. K. S.; Luten, J.; Van Maarseveen, J. H.; Schoemaker, H. E.; Hiemstra, H.; Rutjes, F. P. J. T. J. Org. Chem. 2002, 67, 7869.

16. For some recent examples of the use of silyl enol ethers $\mathbf{3 E}, \mathbf{F}$ in N-acyliminium ion chemistry, see: (a) Louwrier, S.; Tuynman, A.; Hiemstra, H. Tetrahedron 1996, 52, 2629. (b) Kobayashi, S.; Ishitani, H.; Komiyama, S.; Oniciu, D. C.; Katritzky, A. R. 
Tetrahedron Lett. 1996, 37, 3731. (c) Marchioro, C.; Pentassuglia, G.; Perboni, A.; Donati, D. J. Chem. Soc., Perkin Trans. 1 1997, 463. (d) Katritzky, A. R.; Fang, Y.; Silina, A. J. Org. Chem. 1999, 64, 7622. (e) Sugiura, M.; Kobayashi, S. Org. Lett. 2001, 3, 477. (f) Okitsu, O.; Suzuki, R.; Kobayashi, S. J. Org. Chem. 2001, 66, 809.

17. (a) Hatakeyama, S.; Sugawara, K.; Kawamura, M.; Takano, S. Tetrahedron Lett. 1991, 32, 4509. (b) Hatakeyama, S.; Sugawara, K.; Takano, S. Tetrahedron Lett. 1991, 32, 4513. (c) Hatakeyama, S.; Kawamura, M.; Takano, S. J. Am. Chem. Soc. 1994, 116, 4081. (d) Hatakeyama, S.; Yoshida, M.; Esumi, T.; Iwabuchi, Y.; Irie, H.; Kawamoto, T.; Yamada, H.; Nishizawa, M. Tetrahedron Lett. 1997, 38, 7887.

18. More applications of this nucleophile in $\mathrm{N}$-acyliminium ion chemistry are currently under investigation: Mentink, G.; van Maarseveen, J. H.; Hiemstra, H. Org. Lett. 2002, 4, 3497.

19. (a) Kobayashi, S. Synlett 1994, 689. (b) Kobayashi, S. Eur. J. Org. Chem. 1999, 15.

20. Mioskowski did report the formation of bis-amides as a byproduct (see reference 10).

21. For a recent example of the use of vinylogous silyl enol ether $3 \mathbf{L}$ in $\mathbf{N}$-acyliminium ion chemistry, see: Hanessian, S.; Reddy, B. Tetrahedron 1999, 55, 3427.

22. For reviews on vinylogous Mannich reactions, see: (a) Liras, S.; Lynch, C. L.; Fryer, A. M.; Vu, B. T.; Martin, S. F. J. Am. Chem. Soc. 2001, 123, 5918. (b) Bur, S. K.; Martin, S. F. Tetrahedron 2001, 57, 3221.

23. For some examples, see: (a) Ben-Ishai, D.; Sataty, I.; Bernstein, Z. Tetrahedron 1976, 32, 1571. (b) Shono, T.; Matsumura, Y.; Tsubata, K.; Takata, J. Chem. Lett. 1981, 1121. (c) Ciufolini, M. A.; Wood, C. Y. Tetrahedron Lett. 1986, 27, 5085. (d) Herborn, C.; Zietlow, A.; Steckhan, E. Angew. Chem. Int. Ed. 1989, 28, 1392. (e) Katritzky, A. R.; Pernak, J.; Fan, W. -Q. Synthesis 1991, 868.

24. See for example: (a) Drueckhammer, D. G.; Barbas, C. F.; Nozaki, K.; Wong, C. -H.; Wood, C. Y.; Ciufolini, M. A. J. Org. Chem. 1988, 53, 1607. (b) Dondoni, A.; Franco, S.; Junquera, F.; Merchan, F. L.; Merino, P.; Tejero, T. J. Org. Chem. 1997, 62, 5497.

25. (a) Demir, A. S.; Tanyeli, C.; Cagir, A.; Tahir, M. N.; Ulku, D. Tetrahedron: Asymmetry 1998, 9, 1035. (b) Zhang, H.; Xia, P.; Zhou, W. Tetrahedron: Asymmetry 2000, 11, 3439.

26. Niyazymbetov, M. E.; Rongfeng, Z.; Evans, D. H. J. Chem. Soc., Perkin Trans. 2 1996, 1957.

27. Harding, K. E.; Coleman, M. T.; Liu, L. T. Tetrahedron Lett. 1991, 32, 3795.

28. Zaugg, H. E.; Freifelder, M.; Glenn, H. J.; Horrom, B. W.; Stone, G. R.; Vernsten, M. R. J. Am. Chem. Soc. 1956, 78, 2626;

29. Horowitz, R. M.; Geissman, T. A. J. Am. Chem. Soc. 1950, 72, 1518.

30. Hart, D. J.; Kanai, K.; Thomas, D. G.; Yang, T. -K. J. Org. Chem. 1983, 48, 289.

31. Veenstra, S. J.; Hauser, K.; Schilling, W.; Betschart, C.; Ofner, S. Bioorg. Med. Chem. Lett. 1996, 6, 3029.

32. Kim, G.; Jung, S. D.; Kim, W.-J. Org. Lett. 2001, 3, 2985.

33. Moody, C. J.; Hunt, J. C. A. Synlett 1998, 7, 733. 